FERNANDO PARANAIBA FILGUEIRA

INFLUÊNCIA DA CASTRAÇÃO SOBRE O COMPORTAMENTO LEUCOCITÁRIO E EXPRESSÃO DE MOLÉCULAS DE ADESÃO NA MICROCIRCULAÇÃO MESENTÉRICA DE RATOS 
FERNANDO PARANAIBA FILGUEIRA

\section{INFLUÊNCIA DA CASTRAÇÃO SOBRE O COMPORTAMENTO LEUCOCITÁRIO E EXPRESSÃO DE MOLÉCULAS DE ADESÃO NA MICROCIRCULAÇÃO MESENTÉRICA DE RATOS}

Dissertação apresentada ao Programa de Pós-Graduação em Farmacologia do Instituto de Ciências Biomédicas da Universidade de São Paulo, para obtenção do Título de Mestre em Ciências.

São Paulo 


\section{FERNANDO PARANAIBA FILGUEIRA}

\section{INFLUÊNCIA DA CASTRAÇÃO SOBRE O COMPORTAMENTO LEUCOCITÁRIO E EXPRESSÃO DE MOLÉCULAS DE ADESÃO NA MICROCIRCULAÇÃO MESENTÉRICA DE RATOS}

Dissertação apresentada ao Programa de Pós-Graduação em Farmacologia do Instituto de Ciências Biomédicas da Universidade de São Paulo, para obtenção do Título de Mestre em Ciências.

Área de Concentração: Farmacologia

Orientadora: Profa. Dra. Maria Helena Catelli de Carvalho 
Dedico este trabalho aos meus pais, José Claro e Virgínia, por todo o suporte de vida que sempre me forneceram e principalmente pelo incentivo incondicional, que continua possibilitanto a realização de meus sonfros; Aos meus irmãos, Amauri, José Carlos e Naiara, que juntamente com meus pais e esposa, constituem um verdadeiro alicerce familiar. 


\section{AGRADECIMENTO ESPECIAL}

Agradeço em especial à minha esposa ㅅúbia Lobato, pelo amor, carinho, dedicação, paciência e compreensão durante esse período do mestrado. Pelo incentivo e ajuda nos experimentos e escrituração da dissertação. Obrigado também pela amizade, companfia e sorrisos agradáveis que me alegram todos os dias. Enfim, por tudo que você, Amor, representa na minha vida, $\mathcal{T E}$ AMO!!! 


\section{AGRADECIMENTOS}

À Dra. Maria Helena Catteli de Carvalho, em primeiro lugar pela confiança e acolhida em seu laboratório, pelos conselhos e incentivos que serviram como combustível na execução e finalização deste trabalho, pela amizade e discussões científicas, enfim, pela orientação exemplar e sempre harmônica, que contribuem e contribuirão cada vez mais para meu futuro como professor e pesquisador. Lena, a você, meu sincero agradecimento e admiração.

À minha tia Renata e meu tio Fernando, pelo apoio e carinho dispensados em minha chegada a São Paulo.

Às professoras do grupo de Hipertensão: Dra. Zuleica Bruno Fortes, Dra. Rita de Cássia A. Tostes e Dra. Dorothy Nigro, pelo apoio e estrutura dos laboratórios. Em especial à professora Zuleica, pelos ensinamentos, discussões e "papers" que muito contribuíram para a realização deste trabalho e à professora Rita, pela confiança que permitiu meu ingresso neste maravilhoso grupo de pesquisa.

Às secretárias do departamento de Farmacologia, Selma e Julieta (Jú), pelo auxílio com os assuntos burocráticos, pela amizade e pela companhia durantes os cafezinhos matinais.

A todos os técnicos do laboratório de hipertensão: Ritinha, pela grande amizade, carinho e festanças em sua casa; Martinha, pela companhia agradável e além de tudo, pelo auxílio nas medidas de pressão arterial dos ratos; Bazinha, pelos ensinamentos de vida, pela prazerosa amizade, pelas festas e danças oferecidas em sua casa também, e sem contar pelo auxílio na castração dos ratos; Tonho, pela amizade e pelos momentos de descontrações, além também, do apoio e ensinamentos da técnica de imunohistoquímica.

À técnica e amiga Rosângela (Rô) e seu marido Márcio, que me acolheram com bastante carinho quando da minha chegada em São Paulo, me fornecendo ajuda sempre que necessário, pelos momentos de alegria e prazer no Guarujá, além da realização da técnica de PCR.

À técnica e amiga Cidora, pelos ensinamentos, discussões, auxílio nos relatórios, grande ajuda na padronização do novo sistema, pela colaboração na realização dos parâmetros hemodinâmicos, e principalmente, por todos os 
momentos de alegria e muitas gargalhadas compartilhadas durante esses dois anos de pós-graduação.

Ao bioterista Manoel (Manécas), amigo cujo nome carinhoso que lhe trato não cabe ser mencionado aqui, agradeço pela GRANDE amizade que compartilhamos, um irmão que aqui ganhei, sem contar pelos churrascos e viagens que sempre que possível realizamos, agradeço também a sua esposa Carla (Madame Gisele), seu filho Vitor, seus amigos e agora meus amigos Jorge (Sucuri), Keiti, Alexandre (Brutos) e Antônio Carlos (Cuco), agradeço pela amizade de todos vocês.

Ao João Luiz (Ceará), amigo do departamento vizinho, que além da inteligência, cultiva uma amizade sincera e harmônica, obrigado pelos bons momentos e outros melhores que virão.

Ao Rodrigo, irmão de laboratório e mais do que isto, um grande amigo, que em poucas palavras eu diria: um homem de atitudes com imensas altitudes.

À amiga Simone Marcielly, pela companhia agradável, pelos momentos de felicidades, pela grande disponibilidade sempre dispensada, até sorte de nascermos quase no mesmo dia eu tive, pois assim comemoramos os aniversários juntos. Obrigado também pela ajuda na realização dos leucogramas.

À Eliana (Elika), que de pequeno, só o tamanho, pois é munida de conhecimentos e atitude exemplares, e que sem dúvida contribuíram muito na realização deste projeto, obrigado também, é claro, pela sua amizade.

À Grá, pela amizade, ensinamentos, incentivos e motivações freqüentes, pelos momentos de alegria e prazeres que compartilhamos.

Aos amigos Fernando Carneiro, Fernanda e Zidônia, que ajudaram para que o sonho da pós-graduação se tornasse realidade.

Aos meus amigos de laboratório: André, Andréia, Bia, Eveline, Fernanda, Juliana, Luciana, Márcio, Renatinha, Rossana, Stephen, Tiago e Vivi, cuja amizade e convivência foram de grande importância durante esses dois anos de mestrado.

Aos amigos do Departamento de Fisiologia: Ana Paula, Anderson, Camila, Elane, Gisele e Hild pela amizade e momentos de descontrações.

À Fundação de Amparo à Pesquisa do Estado de São Paulo (FAPESP), que possibilita a realização da pós-graduação através do apoio financeiro. 


\section{RESUMO}

FILGUEIRA, F. P. Influência da castração sobre o comportamento leucocitário e expressão de moléculas de adesão na microcirculação mesentérica de ratos. 2008. 90 f. Dissertação (Mestrado em Ciências) - Instituto de Ciências Biomédicas, Universidade de São Paulo, São Paulo, 2008.

A inflamação pode representar papel importante no início e progresso de doenças cardiovasculares. A testosterona exerce importantes efeitos sobre a função vascular, que se encontra alterada na hipertensão arterial, podendo contribuir assim, para possíveis alterações na resposta inflamatória. Portanto, o objetivo deste projeto foi avaliar a influência da hipertensão e da castração sobre o comportamento leucocitário de rolagem, aderência e migração em vênulas pós-capilares do leito mesentérico de ratos espontaneamente hipertensos (SHR), investigando a participação das moléculas de adesão nesse processo. Para este estudo, foram utilizados ratos normotensos (Wistar intactos), SHRs intactos, e SHRs castrados, com 18 semanas de idade. A concentração sérica de testosterona foi determinada por enzima imuno-ensaio. Foi avaliada a pressão arterial pelo método indireto através de pletismografia de cauda, bem como o peso corpóreo. Foi também realizado o estudo in vivo e in situ do comportamento leucocitário, pela técnica de microscopia intravital, avaliando o rolamento, a aderência e a migração leucocitária. Parâmetros hemodinâmicos como a velocidade do fluxo sangüíneo e a taxa de atrito venular na microcirculação, bem como o número de leucócitos totais circulantes, foram avaliados. Além disso, determinamos a expressão gênica das moléculas de adesão: ICAM-1, VCAM-1 e PECAM-1, por PCR em tempo real e protéica, utilizando a técnica de imunohistoquímica, de P-selectina e ICAM-1. Os SHRs apresentaram aumento dos níveis séricos de testosterona quando comparados aos ratos normotensos e a castração foi eficaz em reduzir a concentração deste hormônio. $O$ peso corpóreo foi semelhante entre os grupos. A castração reduziu de modo significativo a pressão arterial, elevada nos SHRs. A hipertensão promoveu aumento do rolamento e da adesão leucocitária, sem interferir na migração, e a castração reverteu estas alterações. Os parâmetros hemodinâmicos, bem como o número de leucócitos circulantes não diferiram entre os grupos estudados. Os SHRs apresentaram aumento da expressão protéica de P-selectina e ICAM-1 em vênulas mesentéricas. A expressão gênica das moléculas VCAM-1 e PECAM-1 também 
mostrou-se elevada em SHRs. A castração reduziu a expressão de VCAM-1, PECAM-1 e P-selectina, sem interferir na expressão de ICAM-1 nos ratos hipertensos. Com base nesses resultados, podemos sugerir que a hipertensão interfere no comportamento leucocitário e que os andrógenos podem ter participação neste processo. O número de leucócitos circulantes e os parâmetros hemodinâmicos não estão envolvidos nessas alterações. Nos ratos hipertensos, o aumento da expressão das moléculas de adesão P-selectina, ICAM-1, VCAM-1 e PECAM-1 contribuem para o aumento do rolamento e da adesão leucocitária e a castração corrige as alterações do comportamento leucocitário interferindo na expressão dessas moléculas.

Palavras-Chave: Hipertensão. Castração. Comportamento leucocitário. Moléculas de adesão. 


\section{ABSTRACT}

FILGUEIRA, F. P. Influence of castration on the leukocyte behavior and adhesion molecule expression in mesenteric microcirculation of rats. 2008. 90f. Master thesis (Science) - Instituto de Ciências Biomédicas, Universidade de São Paulo, São Paulo, 2008.

Inflammation can have an important role in the beginning and in the progress of the cardiovascular diseases. Testosterone exerts important effects on the vascular function, which is altered in arterial hypertension, contributing for the possible alterations in inflammatory response. Thus, the aim of this study was to evaluate the influence of hypertension and the castration on the leukocytes behavior as rolling, adhesion and migration in post-capillaries venules of the mesenteric bed of spontaneously hypertensive rats (SHR), investigating the participation of the adhesion molecules in this process. In this study we used normotensive rats (intact Wistar), intact SHR and, castrated SHR 18 weeks old. We evaluated the body weight, the blood pressure by tail pletismography and serum testosterone levels by ELISA. In vivo and in situ studies of the leukocyte behavior were performed using intravital microscopy techniques, evaluating leukocyte rolling, adhesion and migration. We also measured hemodynamics parameters like blood flow velocity, venular shear rate in the microcirculation and circulating leukocyte counts. The gene expression of ICAM-1, VCAM-1 and PECAM-1 and protein expression of P-selectin and ICAM-1 were evaluated by Real Time PCR and immunohistochemistry, respectively. SHR showed higher testosterone serum levels compared to Wistar rats and the castration was effective in reducing testosterone levels. We did not observe significant differences in body weight among groups. The castration significantly reduced the high blood pressure present in SHR and reverted the leukocyte rolling and adhesion, which are higher in SHR and had no effect in migration. The hemodynamics parameters and leukocyte counts did not differ among groups. SHR had an increased protein expression for P-selectin and ICAM-1 in mesenteric venules and an increases gene expression for VCAM-1 and PECAM-1. Castration of SHR reduced the expression of VCAM-1, PECAM and P-selectin with no effect in ICAM-1 expression. Taken together, these results suggest that the hypertension interfere in leukocyte behavior and androgens can participate in this process. In addition, circulating leukocyte and hemodynamics parameters are not involved in 
those alterations. The higher expression of adhesion molecules such as P-selectin, ICAM-1, VCAM-1 and PECAM-1 present in hypertensive rats, compared to the normotensive ones, contibute for the higher leukocyte rolling and adhesion. Furthermore, castration correct those alterations of the leukocyte behavior by modulating the expression of the adhesion molecule.

Key Words: Hypertension. Castration. Leukocyte behavior. Adhesion molecule 


\section{LISTA DE ILUSTRAÇÕES}

Figura 1. Modelo representativo do comportamento leucocitário.

Figura 2. Sistema de medida de pressão arterial indireta

Figura 3. Representação do sistema de microscopia intravital. .45

Figura 4. Vênula pós-capilar do mesentério demonstrando o procedimento de medida do diâmetro interno venular.

Figura 5. Vênula pós-capilar do mesentério demonstrando o local de contagem de rolamento dos leucócitos, a área de adesão dos leucócitos e a área de migração dos leucócitos.

Figura 6. Protocolo experimental do comportamento leucocitário .48

Figura 7. Protocolo experimental da velocidade do fluxo sanguíneo. .49

Figura 8. Pressão arterial caudal dos diversos grupos experimentais. .50

Figura 9. Massa corpórea dos diversos grupos experimentais. .51

Figura 10. Concentração sérica de testosterona nos grupos experimentais. .52

Figura 11. Medida do número de leucócitos rolando em vênulas pós-capilares do leito mesentério dos grupos experimentais.

Figura 12. Aderência leucocitária determinada em vênulas pós-capilares do mesentério de ratos pertencentes aos grupos experimentais.

Figura 13. Migração leucocitária determinada em área próxima a vênulas póscapilares presentes no mesentério dos ratos pertencentes aos grupos experimentais. .55

Figura 14. Diâmetro basal e estimulado (LTB4), de vênulas pós-capilares presentes no mesentério dos ratos pertencentes aos grupos experimentais. 
Figura 15. Velocidade do fluxo sanguíneo em vênulas pós-capilares mesentéricas dos grupos experimentais

Figura 16. Cálculo da taxa de atrito em vênulas pós-capilares mesentéricas dos grupos experimentais .58

Figura 17. Expressão protéica de $P$-selectina em vênulas mesentéricas não estimuladas de animais pertencentes aos grupos experimentais 60

Figura 18. Expressão protéica de ICAM-1 em vênulas mesentéricas não estimuladas de animais pertencentes aos grupos experimentais

Figura 19. Expressão gênica de ICAM-1 em vênulas mesentéricas não estimuladas de animais pertencentes aos grupos experimentais

Figura 20. Expressão gênica de VCAM-1 em vênulas mesentéricas não estimuladas de animais pertencentes aos grupos experimentais.

Figura 21. Expressão gênica de PECAM-1 em vênulas mesentéricas não estimuladas de animais pertencentes aos grupos experimentais. .64 


\section{LISTA DE TABELAS}

Tabela 1. Moléculas de Adesão Celular.

Tabela 2. Número de leucócitos total e diferencial (linfócitos, neutrófilos, eosinófilos e monócitos) de ratos pertencentes aos experimentais. .59 


\section{LISTA DE ABREVIATURAS E SIGLAS}

ADAM Androgen deficiency of aging males

AR Receptor de andrógeno

Ang II Angiotensina II

ANOVA Análise de variância

$\mathrm{Ca}^{2+} \quad$ Cálcio

CAM Molécula de adesão celular

$\mathrm{CO}_{2} \quad$ Dióxido de carbono

COX Ciclooxigenase

DAB Diaminobenzidina

DCV Doença Cardiovascular

DOCA-sal Desoxicorticosterona acetato-sal

EDHF Fator hiperpolarizante derivado do endotélio

EPM Erro padrão da média

EROs Espécies reativas de oxigênio

FC Frequência Cardíaca

FDA Food and Drug Administration

HERS Estrogen/Progestin Replacement Study

ICAM-1 Molécula de aderência intercelular-1

ICAM-2 Molécula de aderência intercelular-2

IL-1 Interleucina - 1

IL-4 Interleucina - 4

IL-6 Interleucina - 6

I/R Isquemia e reperfusão

JA Junção aderente

JAM Molécula de adesão juncional

JO Junção de oclusão

LFA-1 Antígeno-1 associado à função linfocitária

L-NAME Éster de N-metil-L-arginina

LPS Lipopolissacarídeo

LTB-4 Leucotrieno $\mathrm{B}_{4}$

MAdCAM-1 Mucosal addressin CAM-1

MAPK Proteína quinase ativada por mitógeno 
MCP-1 Proteína quimiotáxica para monócitos

mg Miligrama

$\mathrm{mmHg} \quad$ Milímetro de mercúrio

$\mathrm{N}$-caderina Caderina neuronal

NF-к $\beta \quad$ Fator nuclear-kappa $\beta$

NO Óxido nítrico

NOS Óxido nítrico sintase

$\mathrm{O}_{2} \quad$ Oxigênio

$\mathrm{O}^{2-} \quad$ Ânion superóxido

ORX Orquidectomizado

PAF Fator ativador plaquetário

PAI-1 Inibidor do ativador de plasminogênio

PBS Tampão fosfato-salina

PCR Reação de Polimerase em Cadeia

PECAM-1 Molécula de aderência celular endotelial-plaquetária-1

PFA Paraformaldeído

$\mathrm{PGl}_{2} \quad$ Prostaciclina

PKA Proteína quinase $\mathrm{A}$

PKC Proteina quinase $C$

PMN Leucócitos polimorfonucleares

RT Transcriptase reversa

SHR Ratos espontaneamente hipertensos

TNF- $\alpha \quad$ Fator de necrose tumoral alfa

TRH Terapia de reposição hormonal

$\mathrm{TXA}_{2}$ Tromboxano $\mathrm{A}_{2}$

VCAM-1 Molécula de aderência vascular - 1

VE-caderina Caderina do endotélio vascular

VLA-4 Antígeno 4 muito lento

$\mathrm{V}_{\text {mean }} \quad$ Velocidade média das hemácias

$\mathrm{V}_{\mathrm{RBC}} \quad$ Red blood cell velocity

WHI Women's Health Initiate

WKY Wistar Kyoto 


\section{SUMÁRIO}

1 INTRODUÇÃO

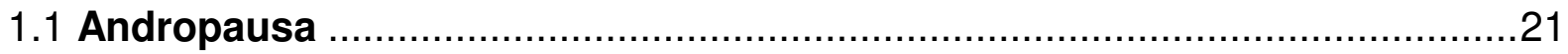

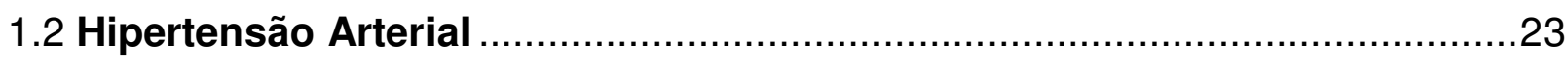

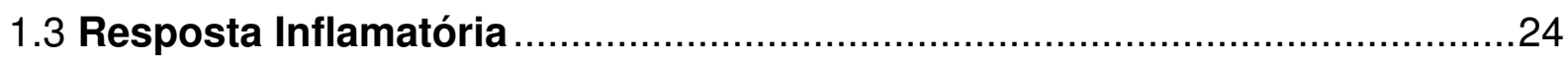

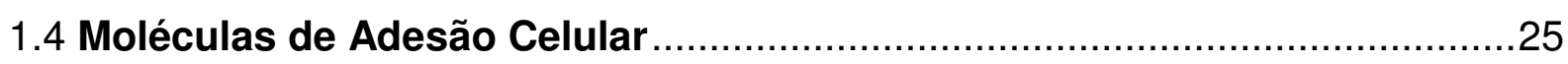

1.5 Proceso Inflamatório na Hipertensão Arterial .........................................28

1.6 Andrógenos e o Processo Inflamatório na Hipertensão Arterial ..................31

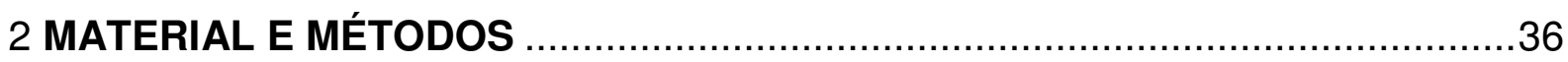

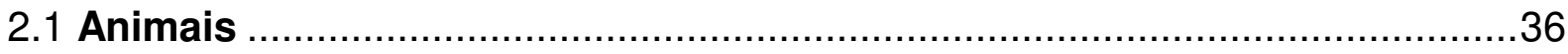

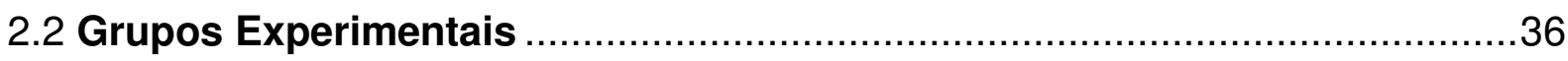

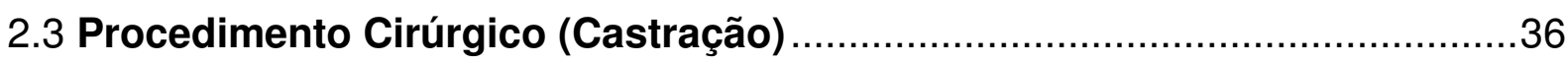

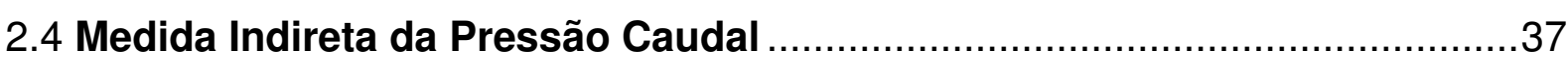

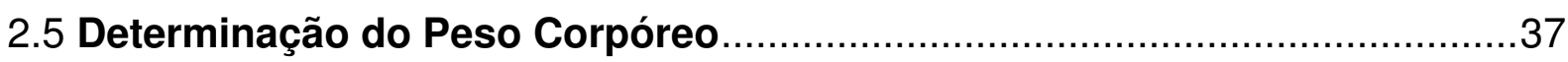

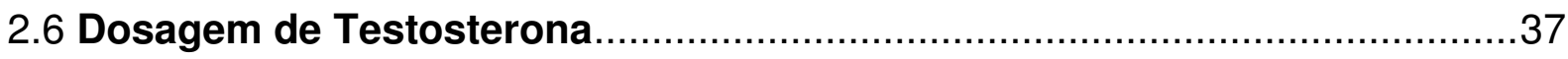

2.7 Estudo do Comportamento Leucocitário na Microcirculação do Mesentério

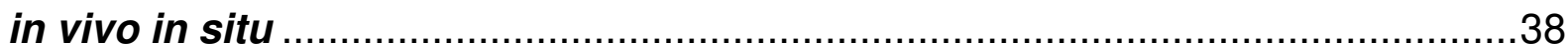

2.7.1 Procedimento Cirúrgico e Preparação do Tecido...........................................38

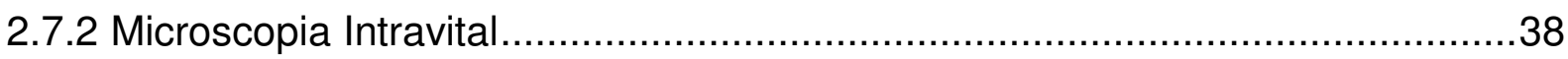

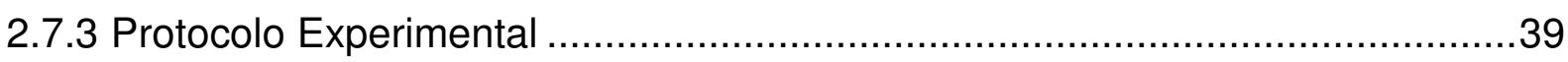

2.8 Velocidade do Fluxo Sanguíneo e Taxa de Atrito Venular .........................40

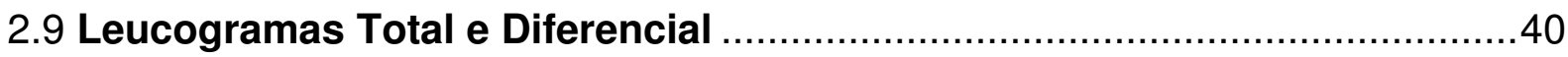

2.10 Determinação da Expressão Protéica de P-selectina e ICAM-1 em Vênulas Mesentéricas: Imunohistoquímica ................................................................

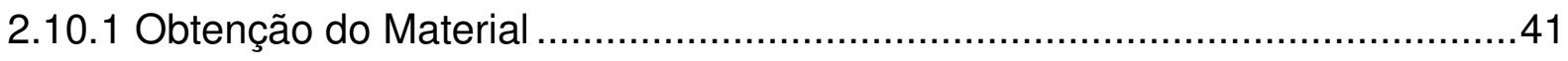

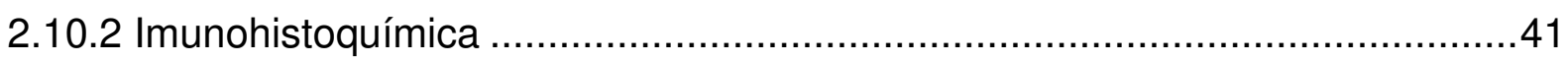

2.11 Determinação da Expressão de RNAm de P-selectina, ICAM-1, VCAM-1 e

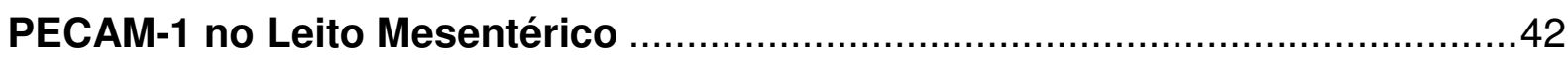

2.11.1 Obtenção do RNAm, Reação de RT (Transcriptase Reversa) e PCR (Reação de Polimerase em Cadeia) em Tempo Real.....................................................42

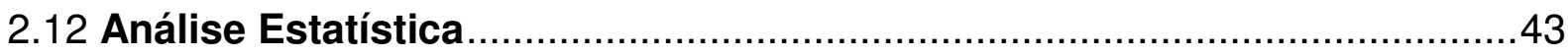

3 RESULTADOS 


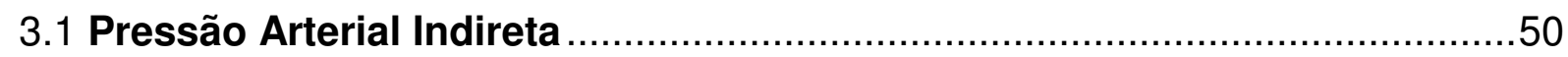

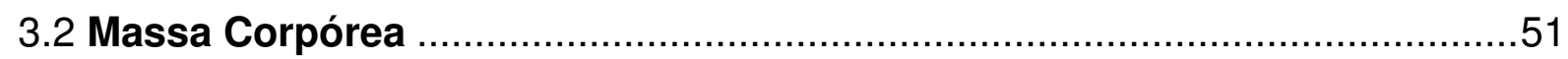

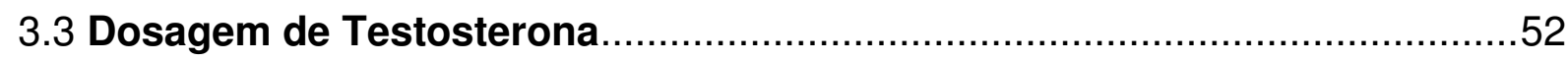

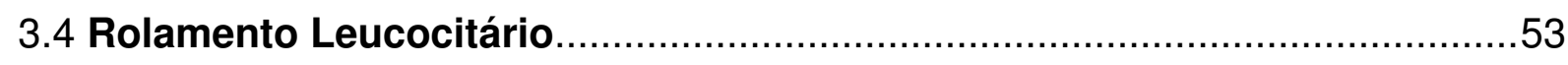

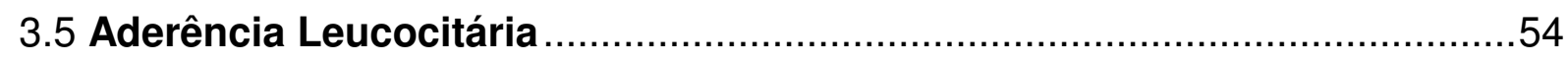

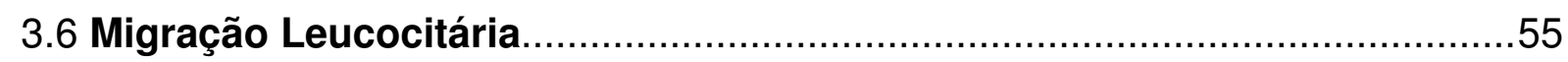

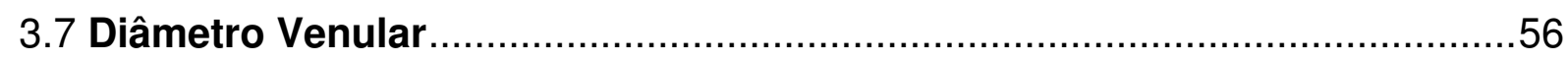

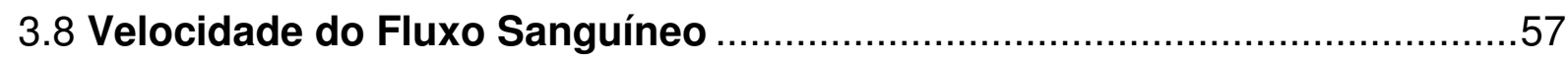

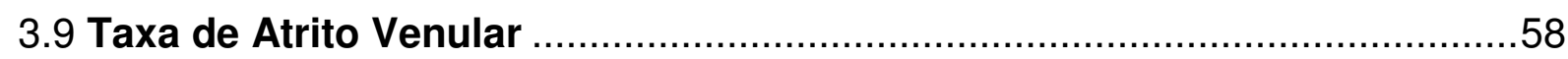

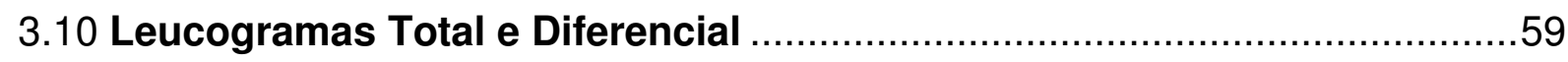

3.11 Imunohistoquímica para Determinação da Expressão Protéica de P-

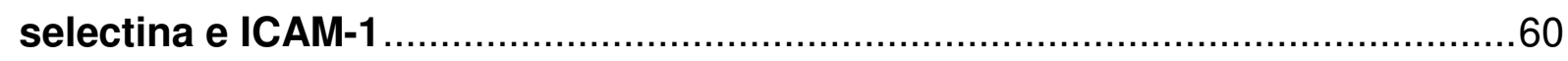

3.12 RT-PCR para Determinação da Expressão Gênica de ICAM-1, VCAM-1 e

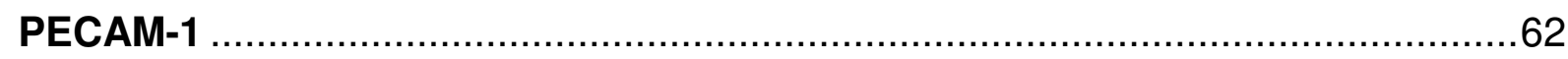

4 DISCUSSÃO

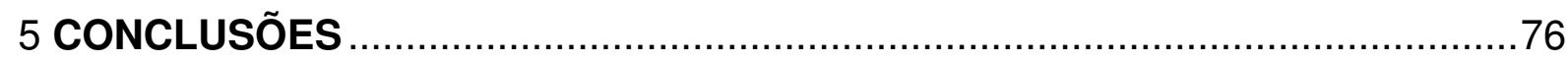

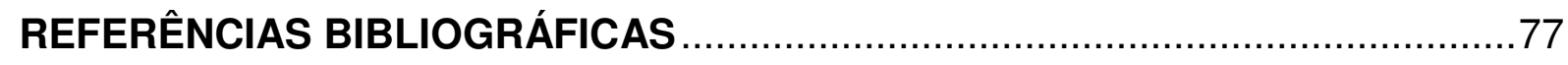




\section{INTRODUÇÃO}

\subsection{Andropausa}

O envelhecimento natural é acompanhado por diminuição na concentração de hormônios circulantes pertencentes a distintos sistemas hormonais, dentre estes, testosterona e estrógeno (LAMBERTS et al., 1997). Sabe-se que a função das gônadas declina com a idade tanto em homens quanto em mulheres, porém, enquanto nas mulheres ocorre uma perda total e relativamente abrupta da função ovariana, nos homens, este fenômeno acontece de maneira gradativa e incompleta (VERMEULEN, 2000). Neste sentido, a andropausa não pode ser definida como condição equivalente à menopausa, e tem sido proposto o uso do termo ADAM (androgen deficiency of aging males) para definir tal situação (LAMBERTS et al., 1997; TARIQ et al., 2005).

O declínio dos níveis de testosterona inicia-se por volta dos 30 anos de idade; esta queda pode ainda ser influenciada por fatores como variabilidade individual, estresse, má alimentação, obesidade e uso de medicamentos (ISIDORI et al., 2005). Os efeitos clássicos associados ao ADAM incluem diminuição da ereção, ejaculação e libido; perda de força e massa muscular; diminuição do crescimento de pêlos pubianos, axilares e faciais; perda de densidade óssea e outros (BASARIA e DOBS, 2003; TARIQ et al., 2005).

A testosterona tem sido utilizada como agente terapêutico, tanto para reversão dos sintomas associados ao ADAM, como também para casos de hipogonadismo. A terapia de reposição hormonal (TRH) com testosterona é empregada, ainda, com a finalidade de facilitar o desenvolvimento de características masculinas, quando a fase da adolescência encontra-se retardada (AN et al., 2003). Além disso, homens e mulheres com idade avançada utilizam a TRH com o objetivo principal de aumentar a massa muscular, fortalecer os ossos e melhorar a libido (RECKELHOFF et al., 2005), e homens, no tratamento da disfunção sexual (MORALES et al., 2004).

O tratamento de mulheres no período da menopausa com diversas preparações e combinações de conjugados estrogênicos associados a progestogênios é uma estratégia utilizada há décadas, sendo tal terapia considerada inicialmente como protetora contra doenças cardiovasculares (DCVs). Entretanto, 
importantes estudos, tais como os HERS I e II (Estrogen/Progestin Replacement Study) e o WHI (Women's Health Initiate), revelaram resultados controversos da $\mathrm{TRH}$ com hormônios femininos em mulheres na pós-menopausa no que se refere à proteção cardiovascular (KHALIL, 2005; RECKELHOFF, 2005). Do mesmo modo, estudos com relação à $\mathrm{TRH}$ com testosterona necessitam ser realizados no sentido de avaliar os possíveis riscos associados ao seu uso.

Poucos estudos relacionados aos efeitos da TRH com testosterona estão disponíveis, principalmente em idosos, quando comparados com aqueles relacionados à $\mathrm{TRH}$ feminina. O Food and Drug Administration (FDA) reprovou há alguns anos uma formulação a base de testosterona para uso em mulheres na menopausa, devido à possibilidade de efeitos adversos sobre o sistema cardiovascular (SPARK, 2005). Entretanto, parâmetros como a dose, a duração de tratamento, a identificação correta dos indivíduos idosos que poderiam se beneficiar, bem como os possíveis efeitos cardiovasculares associados à $\mathrm{TRH}$ com testosterona permanecem sujeitos a estudos (LAMBERTS et al., 1997).

O efeito da idade reduzindo de forma gradativa os níveis androgênicos em homens parece resultar não só da deficiência gonadal, mas também da falência no eixo hipotálamo-pituitário, independentemente da presença de outros fatores predisponentes, como a obesidade ou o uso de medicamentos (HARMAN et al., 2001). Além da idade per se, diversos fatores influenciam os níveis androgênicos, como, por exemplo, fatores genéticos, bem como o consumo de álcool, drogas de abuso, tabaco e a dieta (VERMEULEN, 2000).

Doenças crônicas, tais como hipertensão, diabetes e doença renal crônica estão associadas com redução dos níveis androgênicos, em homens de todas as faixas etárias (TURNER e WASS, 1997; CORRALES et al., 2004). O fato dos níveis androgênicos diminuírem com a idade levou os pesquisadores a presumirem que andrógenos não têm participação nas doenças crônicas cardiovasculares e renais em idosos. Entretanto, estudos têm sugerido que a testosterona, até mesmo em níveis observados em idosos, pode ter conseqüências adversas sobre a função cardiovascular (RECKELHOFF et al., 2005). Deste modo, torna-se relevante a realização de estudos visando compreender os efeitos promovidos pela falta desse hormônio sobre o sistema cardiovascular. 


\subsection{Hipertensão Arterial}

A hipertensão arterial é considerada a causa mais freqüente de morbidade e mortalidade por DCV, condição responsável por uma a cada três mortes em todo o mundo. Nos países em desenvolvimento, o crescimento da população idosa e o aumento da longevidade, associados às mudanças nos padrões alimentares e no estilo de vida, têm forte repercussão sobre o padrão de morbimortalidade, contribuindo de modo significativo para o aumento da incidência de doenças crônicas, como a hipertensão (WORLD HEALTH ORGANIZATION, WHO, 2003). De acordo com estimativas do ano de 2000, a prevalência global de hipertensão foi de aproximadamente $26 \%$, totalizando um bilhão de pessoas, e para 2025 , estima-se que mais de 1,5 bilhões de adultos serão hipertensos (KEARNEY et al., 2005).

Sexo, idade, raça, fatores socioeconômicos e condições como diabetes ou obesidade, estão relacionados com o desenvolvimento da hipertensão (OSTCHEGA et al., 2007). Com relação ao sexo, diversos estudos, epidemiológicos e clínicos, têm demonstrado de maneira evidente a maior prevalência de hipertensão em homens quando comparados à mulheres que se encontram no período fértil. Nos estudos experimentais, esta diferença também já foi confirmada em diversos modelos, como por exemplo: ratos espontaneamente hipertensos - SHR (spontaneously hypertensive rat) (CHEN e MENG, 1991; SILVA-ANTONIALLI et al., 2000; DANTAS et al., 2004), ratos hipertensos tratados com deoxicorticosterona - DOCA-sal (OUCHI et al., 1987; CROFTON e SHARE, 1997; TOSTES et al., 2000), ratos Dahl salsensível (ROWLAND e FREGLY, 1992), ratos geneticamente hipertensos - New Zealand (ASHTON e BALMENT, 1991) e camundongos com hipertensão induzida por angiotensina-II (XUE et al., 2005). Nesses modelos sugere-se que os hormônios sexuais femininos podem proteger contra o desenvolvimento de hipertensão. De fato, em nosso laboratório foi observado que fêmeas SHR e DOCA-sal apresentam hipertensão menos severa do que os machos de mesma idade e que a ovariectomia agrava a hipertensão arterial em ambos os modelos, enquanto que o tratamento hormonal com estradiol atenua o desenvolvimento dessa condição (TOSTES et al., 2000; DANTAS et al., 2004).

Estudos indicam que em mulheres no período pós-menopausa, o ovário é considerado uma fonte importante de andrógenos (LAUGHLIN et al., 2000). Além disso, na síndrome do ovário policístico, as mulheres apresentam aumento dos 
níveis androgênicos seguido de elevação da pressão arterial (TALBOTT et al., 1995). Portanto, é possível que com a perda de estrógeno na menopausa, o efeito dos andrógenos, possa contribuir para a elevação da pressão arterial na pósmenopausa.

Em modelos animais, a influência da testosterona sobre a pressão arterial também tem sido observada, com a castração química ou cirúrgica reduzindo os níveis pressóricos em ratos hipertensos (RECKELHOFF, 2001). Entretanto, pouco se sabe sobre os mecanismos pelos quais a testosterona exerce tais efeitos, ou como ela poderia influenciar a função vascular nesta condição.

\subsection{Resposta Inflamatória}

Os leucócitos, envoltos pela camada de eritrócitos, ocupam a área central da corrente sanguínea (zona axial) e o plasma a área mais adjacente ao endotélio (zona plasmática). Durante o desenvolvimento da resposta inflamatória, a distribuição dos leucócitos e eritrócitos circulantes altera-se. Nos estágios iniciais do processo inflamatório, por ação dos mediadores químicos como, por exemplo, a histamina (NATHAN, 2002), ocorre vasodilatação, com conseqüente diminuição da velocidade do fluxo sanguíneo e aumento da permeabilidade vascular. A redução da velocidade do fluxo possibilita maior interação entre eritrócitos que vão gradativamente formando agregados que deslocam os leucócitos para a zona plasmática, promovendo desta forma, maior contato das células brancas com 0 endotélio vascular (FLOREY, 1970; WILHELM, 1977).

Nestas condições, leucócitos passam rolando sobre 0 endotélio com velocidade menor que os eritrócitos, localizados agora no centro da corrente sanguínea, e passam então a aderir, momentaneamente, à parede do vaso (KELLY et al., 2007). A duração do contato celular aumenta gradualmente e, finalmente, dependendo do estímulo, os leucócitos permanecem aderidos ao endotélio. Após a adesão das células inflamatórias circulantes, como neutrófilos, à parede vascular, ocorre subseqüente migração em direção ao interstício, um processo complexo e que envolve interações específicas ligante-receptor de células sanguíneas e endoteliais (COOPER et al., 2002).

Estas interações que participam da reação inflamatória, tornan o organismo capaz de se defender contra microorganismos infecciosos, podendo também causar 
efeitos deletérios se os mecanismos reguladores da resposta inflamatória estão alterados ou respostas imunes a produtos microbianos residuais ou a componentes teciduais provocam uma resposta inflamatória persistente. Em tais circunstâncias, a defesa dos leucócitos pode se transformar em ataque contra o próprio organismo podendo levar á destruição tecidual (WEISS, 1989). Torna-se assim, de grande importância a caracterização destas interações bem como das moléculas de adesão celular (cell adhesion molecule - CAM) envolvidas nesse processo, em condições onde existe disfunção vascular.

\subsection{Moléculas de Adesão Celular}

As CAMs são expressas (constitutivamente ou não) na superfície celular. Cada um dos três estágios de recrutamento leucocitário, que incluem rolamento, adesão e migração transendotelial, envolve a participação de diferentes famílias de moléculas de adesão (KUBES, 2002) (Tabela 1).

O evento de rolamento leucocitário (Figura 1) é predominantemente mediado pelas CAMs da família das selectinas, que são responsáveis pela interação inicial que ocorre entre leucócito e endotélio (HENRICKS; NIJKAMP, 1998), resultando na redução da velocidade das células circulantes ("rollers"). As selectinas são estruturalmente muito similares e possuem a presença do terminal amino dependente de cálcio e seus ligantes são estruturas constituídas de carboidratos associados ao ácido siálico (PATEL, 2002). Os membros dessa família incluem: a Pselectina (CD62P), proteína constitutiva, originalmente purificada de plaquetas, mas também expressa nas células endoteliais, em grânulos secretores - grânulos $\alpha$ em plaquetas e corpúsculos de Weibel-Palade (HSU-LIN et al., 1984; McEVER et al., 1989)a E-selectina (CD62E), expressa nas células endoteliais (BEVILACQUA et al., 1987) e a L-selectina (CD62L), expressa constitutivamente na membrana de leucócitos (SPERTINI et al., 1991).

Nas etapas seguintes do processo inflamatório (adesão e migração celular Figura 1) ocorre ativação das integrinas e imunoglobulinas. A família das integrinas é composta por glicoproteínas transmembranas compostas por duas ligações não covalentes associadas a heterodímeros designados sub-unidades $\alpha\left(\alpha_{L}, \alpha_{M}, \alpha_{X}\right.$ e $\left.\alpha_{d}\right)$ e $\beta$ ( $\beta 1, \beta 2$ e $\beta 3)$. O heterodímero CD11a/CD18 ( $\left.\alpha_{\llcorner} \beta_{2}\right)$ é expresso constitutivamente na superfície de leucócitos e interage com as moléculas de adesão da superfamília 
das imunoglobulinas expressas nas células endoteliais: ICAM-1, 2 e 3 (intercellular adhesion molecules-1, 2 e 3). O heterodímero CD11b/CD18 $\left(\alpha_{M} \beta_{2}\right)$ é expresso em leucócitos, sendo estocado em grânulos, cuja mobilização para a superfície celular requer a ativação leucocitária. Os ligantes para CD11b/CD18 incluem as ICAMs-1 e 2 das células endoteliais, componentes da matriz extracelular, como fibronectina e laminina, e fragmentos do sistema complemento (HUBBARD e ROTHLEIN, 2000; BÉCHARD et al., 2001).

Embora a visão prevalente seja que as selectinas medeiam o rolamento, enquanto que as integrinas sejam responsáveis pela aderência, há algumas exceções. O melhor exemplo caracterizado é a VLA-4 (very late antigen 4) ou $\alpha_{4} \beta_{1}$, um membro da família das integrinas que pode mediar o rolamento leucocitário (JOHNSTON et al., 1996).

A superfamília das imunoglobulinas compreende um grupo de moléculas caracterizadas pela presença de dois ou mais domínios semelhantes às imunoglobulinas. Dentre os membros desta superfamília, cinco moléculas têm sido implicadas como principais mediadoras da interação leucócito-endotélio: ICAM-1, ICAM-2, PECAM-1 (platelet/endothelial CAM-1), VCAM-1 (vascular CAM-1) e MAdCAM-1 (mucosal addressin CAM-1). A ICAM-1 (CD54) e a ICAM-2 (CD102) são expressas constitutivamente na superfície de células endoteliais, e estas são ativadas por citocinas (TNF- $\alpha$, IL-1 e IL-4), a ICAM-1 pode ter sua expressão aumentada, diferentemente da ICAM-2, que não tem sua expressão afetada por mediadores inflamatórios (TAILOR e GRANGER, 2000; KRIEGLSTEIN e GRANGER, 2001).

A PECAM-1 (CD31), cuja expressão é constitutiva, concentra-se nas junções das células endoteliais, nos leucócitos e nas plaquetas, regulando principalmente 0 processo de transmigração de plaquetas e leucócitos (DANGERFIELD et al., 2002). Além disso, parece regular também a adesão de neutrófilos ao endotélio, por sua habilidade de ativar as $\beta 1$ e $\beta 2$ integrinas (TANAKA et al., 1992; PIALI et al., 1993). A VCAM-1 (CD106) exibe um nível baixo de expressão constitutiva sobre células endoteliais, entretanto sua expressão pode ser aumentada por um mecanismo dependente de transcrição - NF-kappaB (nuclear factor - kappaB) (NORMAN et al., 2003). VCAM-1 participa do recrutamento de células sanguíneas pelo endotélio ativado para favorecer sua adesão firme. A MAdCAM-1 é uma molécula de adesão 
que parece ser restrita a sítios intestinais e primariamente medeia o recrutamento de linfócitos neste órgão (BRISKIN et al., 1997).

\section{Outras Moléculas de Adesão}

Além das CAMs já citadas, cuja participação nos processos envolvidos no comportamento leucocitário já está bem descrita, as proteínas juncionais das células endoteliais têm atraído grande atenção nos últimos anos no que tange à participação na transmigração leucocitária.

As células endoteliais aderem-se umas às outras através de estruturas juncionais formadas por proteínas transmembrana adesivas que são responsáveis pela adesão homofílica célula a célula (BAZZONI e DEJANA, 2004). Essas junções controlam diferentes características da homeostase vascular, como, por exemplo, a permeabilidade a solutos plasmáticos. O extravasamento de leucócitos e a infiltração para as áreas inflamadas requerem processos de abertura e fechamento finamente regulados que envolvem o contato célula a célula (MULLER, 2003). Desse modo, o endotélio regula ativamente o extravasamento de fluidos e macromoléculas. Danos na função de barreira do endotélio resultam em extravasamento vascular e edema. Isto pode ocorrer no endotélio das vênulas pós-capilares por exposição a agentes vasoativos como a histamina ou durante o processo inflamatório. Acredita-se que o aumento da permeabilidade vascular induzido por agentes vasoativos seja causado pela interação actina-miosina na periferia das células endoteliais. As forças contráteis assim geradas causam pequenas aberturas entre as junções das células, contribuindo assim para o extravasamento de fluídos (CURRY, 1992).

Nas células endoteliais dois tipos de junções intercelulares são particularmente relevantes: a junção de oclusão (JO) ou tight junction e a junção aderente (JA) ou zonula adherens. A JO constitui uma região de extrema proximidade das membranas plasmáticas das células adjacentes, formando um anel contínuo ou zônula ao redor das células epiteliais, constituindo uma barreira que limita a difusão de íons e solutos pela via paracelular (COLLARES-BUZATO et al., 2001). A JA constitui um dispositivo eficaz de adesão intercelular e está envolvida na regulação da permeabilidade da JO (BROWN e DAVIS, 2002).

Quanto à composição das junções, varias proteínas têm sido identificadas. A JO é constituída por três classes de proteínas transmembrana: as claudinas, a ocludina e a molécula de adesão juncional (junction adhesion molecule - JAM). As 
claudinas formam dímeros que se ligam às claudinas da célula adjacente de forma homotípica ou heterotípica, formando o primeiro elo de contato intercelular (FURUSE et al., 1999). As claudinas associam-se também à ocludina (FURUSE et al., 1993), importante proteína regulatória da função de barreira paracelular. A outra proteína integral do complexo juncional é a JAM, membro de uma superfamília de imunoglobulinas, cuja função está relacionada à regulação da migração de leucócitos pela via paracelular (MARTìN-PADURA et al., 1998).

A JA contém, como um de seus principais componentes a caderina, uma molécula de adesão dependente de cálcio expressa em diversos tipos de tecidos com alguma especificidade. As células endoteliais expressam duas principais caderinas, N- e VE-caderinas (vascular endothelial cadherin). A caderina ancorada ao citoesqueleto de actina estabiliza a estrutura juncional e contribui para a manutenção da morfologia e controle da motilidade celular (GEIGER e AYALON, 1992).

\subsection{Processo Inflamatório na Hipertensão Arterial}

Trabalhos têm demonstrado que a inflamação pode representar papel importante no início e progresso de DCVs. A designação de DCV como um processo inflamatório crônico é apoiada pelo fato de que fatores de risco para essas doenças, como hipertensão, diabetes e hipercolesterolemia, estão associadas com elevados níveis plasmáticos de marcadores inflamatórios (IL-6, TNF- $\alpha$, MCP-1) promovendo um fenótipo inflamatório e pró-trombótico no sistema vascular (PAULETTO e RATTAZZI, 2006). Esta alteração encontra-se mais pronunciada nas células endoteliais, podendo-se observar estresse oxidativo, aumento da expressão de CAMs, ativação de vias de sinalização celular e conseqüente adesão e ativação de leucócitos e plaquetas (GRANGER et al., 2004). Os neutrófilos ativados podem contribuir para a hipertensão arterial tanto por influenciar a resistência microvascular, como por liberar espécies reativas derivadas do oxigênio (EROs), enzimas proteolíticas ou ambas, levando à lesão da parede vascular (OFOSU-APPIAH et al., 1997).

As células endoteliais representam importante papel na manutenção da homeostase hemodinâmica e diversos estudos associam a disfunção destas células com o desenvolvimento da hipertensão arterial. Além de proporcionar uma barreira 
física entre o lúmen e a parede do vaso, o endotélio regula ativamente o tônus vascular em condições fisiológicas, respondendo a forças mecânicas e a mediadores neurohumorais, além de liberar uma variedade de fatores contráteis e relaxantes (FURCHGOTT e VANHOUTTE, 1989).

O óxido nítrico (NO) liberado pelo endotélio é capaz de promover relaxamento das células do músculo liso vascular e inibir a expressão de CAMs importantes na modulação da interação leucócito-endotélio. Em condições fisiológicas, o NO é constantemente liberado pelo endotélio, porém em condições onde existe disfunção desta célula, pode ocorrer redução da geração e/ou liberação de NO e conseqüentemente da vasodilatação desencadeada por esta substância. A célula endotelial libera ainda outras substâncias vasodilatadoras, como a prostaciclina $\left(\mathrm{PGI}_{2}\right)$, um derivado do ácido araquidônico via ciclooxigenase, importante na inibição da agregação plaquetária, e o fator hiperpolarizante derivado do endotélio (EDHF) (FÉLÉTOU e VANHOUTTE, 1999).

Fatores constritores também podem ser liberados pelo endotélio, como as endotelinas, a angiotensina II, o ânion superóxido $\left(\mathrm{O}_{2}^{-}\right)$e outros fatores constritores derivados da ciclooxigenase, como o tromboxano $A_{2}\left(T X A_{2}\right)$ e a prostaglandina $\mathrm{H}_{2}$ $\left(\mathrm{PGH}_{2}\right.$ ) (FURCHGOTT e VANHOUTTE, 1989; CARVALHO et al., 1996; PASSAGLIA et al., 1998). O equilíbrio entre a formação e/ou liberação desses mediadores proporciona o controle do tônus vascular e da pressão sanguínea.

Sabe-se que na hipertensão arterial ocorre aumento da resistência vascular periférica associado com disfunção endotelial, e a perda da função modulatória exercida pelos fatores derivados do endotélio parece ter participação crítica no desenvolvimento desta condição. As alterações da função endotelial na hipertensão têm sido atribuídas ao desequilíbrio na geração e/ou liberação de mediadores envolvidos na contração e no relaxamento vascular (CARVALHO et al., 1996; FERRO et al., 1996; PASSAGLIA et al., 1998), e estes últimos podem exercer importante papel antiinflamatório (SHEN et al., 1995), com sua perda propiciando o desenvolvimento do processo inflamatório, incluindo aumento da interação leucócitoendotélio.

Além de controlar o tônus vascular, as células endoteliais são responsáveis por regular o tráfico de leucócitos do sangue para os tecidos e manter o equilíbrio antitrombótico e anticoagulante do fluxo sanguíneo. Conforme mencionado anteriormente, o recrutamento leucocitário é controlado pela expressão de 
moléculas de adesão capazes de atrair e firmemente aderir leucócitos após estímulo com citocinas e outros fatores inflamatórios. A perda ou desregulação desses mecanismos devido à ativação da célula endotelial está associada com o desenvolvimento da disfunção endotelial (BIJL, 2003).

A célula endotelial pode ser ativada pela estimulação com diferentes agentes, tais como, as citocinas, cujos níveis encontram-se elevados na hipertensão. A ativação endotelial é caracterizada por alterações como perda da integridade vascular, aumento da expressão de CAMs, alteração do fenótipo antitrombótico para trombótico e produção de diversas citocinas, permitindo que a célula endotelial participe da resposta inflamatória. Os mecanismos que levam à ativação endotelial permanecem desconhecidos. Estudos sugerem que fatores de risco como hipertensão, diabetes e obesidade possam estar relacionados com o desenvolvimento dessa alteração, e conseqüentemente para a disfunção endotelial presente nestas condições (BIJL, 2003).

Estudos epidemiológicos, clínicos e experimentais proporcionaram evidências consideráveis a respeito da associação entre hipertensão arterial e resposta inflamatória vascular. Pacientes com hipertensão arterial leve a moderada, sem doença arterial coronariana, possuem níveis plasmáticos elevados de mediadores inflamatórios, incluindo ICAM e VCAM solúveis (PARISSIS et al., 2000; PARISSIS et al., 2002).

Sabe-se que a elevação do número de leucócitos circulantes, especialmente neutrófilos e monócitos, representa fator de risco para complicações cardiovasculares (PRENTICE et al., 1982; ERNST et al., 1987), por dificultar a hemodinâmica microvascular (BRAIDE et al., 1984) e produzir substâncias como as EROs, que promovem a lesão dos tecidos adjacentes (WEISS et al., 1982). Neste sentido, demonstrou-se que SHRs e ratos hipertensos Dahl sal-sensíveis possuem elevado número de leucócitos circulantes, os quais também estão mais ativados, quando comparados ao Wistar Kyoto (WKY) e a Dahl sal-resistentes, respectivamente (SCHMID-SCHÖNBEIN et al., 1991; SHEN et al., 1995). Além disso, demonstrou-se que leucócitos polimorfonucleares (PMN) periféricos estão ativados em pacientes com hipertensão essencial. Os leucócitos PMN ativados são destruídos por auto-necrose e, simultaneamente, recrutam ativamente mais leucócitos PMN na circulação, exacerbando a inflamação e o estresse oxidativo nestes pacientes (KRISTAL et al., 1998). 
A interação leucócito-endotélio pode também influenciar o tônus vascular ao interferir na liberação dos fatores relaxantes e contráteis pelo endotélio (MEHTA et al., 1991). A hipótese de que os neutrófilos podem participar da elevação da resistência vascular periférica em animais hipertensos foi levantada em nosso laboratório (NIGRO et al., 1994), ao se observar que a contração dependente de endotélio foi induzida por neutrófilos em vasos de SHRs. Além disso, enzimas produzidas por neutrófilos podem ativar a pró-renina, aumentando a produção de renina e Ang II, favorecendo a elevação da pressão arterial (DZAU et al., 1987).

Em resumo, embora esteja bem estabelecido que na hipertensão existe disfunção endotelial, e que esta condição pode estar associada com a ativação endotelial, que contribui para o desenvolvimento do processo inflamatório, os dados referentes ao comportamento leucocitário na hipertensão são escassos e contraditórios.

\subsection{Andrógenos e o Processo Inflamatório na Hipertensão Arterial}

Embora os mecanismos responsáveis pela diferença sexual no controle da pressão sanguínea permaneçam incertos, há significantes evidências de que os andrógenos, como por exemplo, a testosterona, represente papel importante na diferença de gênero associada à regulação da pressão sanguínea (RECKELHOFF, 2001).

O efeito de andrógenos sobre o tônus vascular é demonstrado em estudos que indicam a participação da testosterona em mecanismos envolvidos tanto na contração quanto no relaxamento vascular (HUTCHISON et al., 1997). Essas ações vasculares da testosterona podem ser mediada por mecanismos genômicos, via receptores de andrógeno (ARs), ou não genômicos. Para que ocorram os efeitos genômicos, a testosterona deve ser transportada ao interior da célula e ligar-se ao AR citoplasmático, formando complexo que irá se dirigir ao núcleo. Uma vez no núcleo, a testosterona liga-se ao elemento de resposta a hormônio, localizado na região promotora do gene alvo, alterando a transcrição e, conseqüentemente, a tradução protéica. As ações não genômicas diferenciam-se das genômicas por apresentarem resposta rápida, insensibilidade à inibição da síntese de RNA e de proteínas, e pelo fato que esteróides incapazes de atingir o núcleo poderem produzir tais efeitos, que em sua maioria não são bloqueados por antagonistas clássicos de 
ARs. Os efeitos não genômicos dos andrógenos geralmente envolvem rápida ativação de vias de sinalização e indução de segundos mensageiros, aumento do cálcio citosólico, ativação das proteínas quinases $A$ e $C$ (PKA e PKC, respectivamente) e ativação de quinases ativadas por mitógenos (MAPKs) levando a diferentes efeitos celulares (HEINLEIN e CHANG, 2002).

Os receptores para andrógenos (ARs) estão presentes em vários tipos celulares, tais como células de musculatura esquelética, fibroblastos, mastócitos, células endoteliais e de músculo liso vascular (SINHA-HIKIM et al., 2004; LITTLETON-KEARNEY e HURN, 2004). No sistema vascular, demonstrou-se que a testosterona aumenta a vasoconstrição coronariana induzida por $\mathrm{TXA}_{2}$ em cobaias (SCHROR et al., 1994). Além disso, o pré-tratamento da artéria coronária suína com concentrações fisiológicas de testosterona prejudica o relaxamento vascular dependente do endotélio induzido por bradicinina (QUAN et al., 1999). Entretanto, outros estudos têm demonstrado que a testosterona induz relaxamento dependente do endotélio (via produção de NO, por exemplo) e/ou independente do endotélio (pela modulação de canais iônicos, por exemplo) da aorta de ratos e coelhos, e da coronária de coelhos, cães e porcos (YUE et al., 1995; CHOU et al., 1996; COSTARELLA et al., 1996; CREWS e KHALIL, 1999a; CREWS e KHALIL, 1999b; HONDA et al., 1999; MURPHY e KHALIL, 1999).

Considerando que na hipertensão existe desequilíbrio na produção de fatores contráteis e relaxantes derivados do endotélio, e que estes últimos podem exercer importante papel antiinflamatório (SHEN et al., 1995), os efeitos da testosterona sobre o tônus vascular podem interferir no processo inflamatório, contribuindo para as alterações vasculares presentes nesta condição. De fato, estudos sugerem que a liberação de NO pelo endotélio é maior em artérias de fêmeas quando comparadas com os machos (KNOT et al., 1999; ORSHAL e KHALIL, 2004). Kähönen e colaboradores (1998) demonstraram que o inibidor da NOS, $N^{\omega}$-nitro-L-arginine methyl ester (L-NAME), atenua o relaxamento à acetilcolina de modo mais efetivo em fêmeas SHR e WKY quando comparadas a machos. Além disso, estes autores demonstraram que o relaxamento ao nitroprussiato de sódio, um doador exógeno de NO, em anéis de artéria mesentérica é maior em fêmeas quando comparado a machos SHR.

Neste sentido, Dantas e colaboradores (2004) demonstraram ainda que arteríolas mesentéricas de SHRs machos apresentam maior concentração de $\mathrm{O}_{2}{ }^{-}$ 
sob condições basais quando comparados às fêmeas. Em condições fisiológicas, as EROs são produzidas de maneira controlada em baixas concentrações e funcionam como moléculas de sinalização regulando a função endotelial e o tônus vascular. Entretanto, sob condições patológicas, o aumento na geração das EROs leva à disfunção endotelial, aumento da contratilidade, crescimento das células do músculo liso vascular, peroxidação lipídica, aumento da deposição de proteínas da matriz extracelular, migração de monócitos e maior expressão de CAMs, fatores envolvidos na lesão vascular da hipertensão (TOUYZ et al., 2004). De fato, estudos mostram que os andrógenos podem estimular a expressão de CAMs na superfície de células endoteliais (McCROHON et al., 1999; DEATH et al., 2004).

Em resumo, embora esses dados indiquem a participação dos androgênios em alterações da resposta inflamatória observadas na hipertensão arterial, podendo assim, contribuir para a aumentada incidência de DCVs no sexo masculino, pouco se sabe sobre o papel desses hormônios especificamente nos processos envolvidos no comportamento leucocitário na hipertensão.

Considerando que trabalhos referentes às alterações da resposta inflamatória em modelos experimentais de hipertensão são controversos e que estudos demonstram que a testosterona exerce importantes efeitos sobre a função vascular, que se encontra alterada na hipertensão arterial, o objetivo deste projeto foi avaliar a influência da hipertensão e da castração sobre o comportamento leucocitário de rolagem, aderência e migração em vênulas pós-capilares do leito mesentérico de ratos espontaneamente hipertensos. Avaliaremos ainda a participação das moléculas de adesão nessas alterações. 
Tabela 1 - Moléculas de Adesão Celular

\begin{tabular}{|c|c|c|c|c|}
\hline CAM & Sinônimos & Principais ligantes & Função & Localização \\
\hline \multicolumn{5}{|l|}{ Selectinas } \\
\hline P-selectina & CD62P & L-selectina, PSGL-1 & Rolamento & $\begin{array}{l}\text { Endotélio, } \\
\text { plaquetas }\end{array}$ \\
\hline E-selectina & CD62E & $\begin{array}{l}\text { L-selectina, } \\
\text { ESL-1, PSGL-1 }\end{array}$ & Rolamento & Endotélio \\
\hline L-selectina & CD62L & $\begin{array}{l}\text { P-, E-selectina, } \\
\text { MAdCAM-1 }\end{array}$ & Rolamento & Leucócitos \\
\hline \multicolumn{5}{|l|}{ Integrinas } \\
\hline$\alpha 4 \beta 1$ integrina & $\begin{array}{l}\text { VLA-4, } \\
\text { CD49d/CD29 }\end{array}$ & VCAM-1 & Adesão & $\begin{array}{l}\text { Linfócitos, } \\
\text { monócitos }\end{array}$ \\
\hline$\alpha L \beta 2$ integrina & $\begin{array}{l}\text { LFA-1, } \\
\text { CD11a/CD18 }\end{array}$ & ICAM-1, -2, -3 & Adesão & Leucócitos \\
\hline$\alpha \mathrm{M} \beta 2$ integrina & $\begin{array}{l}\text { Mac-1, } \\
\text { CD11b/CD18 }\end{array}$ & ICAM-1, -2, iC3b & Adesão & $\begin{array}{l}\text { Neutrófilos, } \\
\text { monócitos }\end{array}$ \\
\hline$\alpha \times \beta 2$ integrina & $\begin{array}{l}\text { Gp 150/95, } \\
\text { CD11c/CD18 }\end{array}$ & ICAM-1, iC3b & Adesão & $\begin{array}{l}\text { Neutrófilos, } \\
\text { monócitos }\end{array}$ \\
\hline $\begin{array}{l}\alpha \mathrm{D} \beta 2 \text { integrina } \\
\text { Imunoglobulinas }\end{array}$ & CD11d/CD18 & ICAM-3, VCAM-1 & Adesão & Linfócitos \\
\hline ICAM-1 & CD54 & $\alpha L \beta 2, \alpha M \beta 2$ & $\begin{array}{l}\text { Adesão, } \\
\text { Migração }\end{array}$ & $\begin{array}{l}\text { Endotélio, } \\
\text { leucócitos }\end{array}$ \\
\hline ICAM-2 & CD102 & $\alpha \mathrm{L} \beta 2, \alpha \mathrm{M} \beta 2$ & $\begin{array}{l}\text { Adesão, } \\
\text { Migração }\end{array}$ & $\begin{array}{l}\text { Endotélio, } \\
\text { leucócitos, } \\
\text { plaquetas }\end{array}$ \\
\hline VCAM-1 & CD106 & $\alpha 4 \beta 1$ & Adesão & Endotélio \\
\hline PECAM-1 & CD31 & PECAM-1 & $\begin{array}{l}\text { Adesão, } \\
\text { Migração }\end{array}$ & $\begin{array}{l}\text { Endotélio, } \\
\text { leucócitos, } \\
\text { plaquetas }\end{array}$ \\
\hline MAdCAM-1 & - & L-selectina, $\alpha 4 \beta 7$ & $\begin{array}{l}\text { Adesão, } \\
\text { Migração }\end{array}$ & Endotélio \\
\hline
\end{tabular}




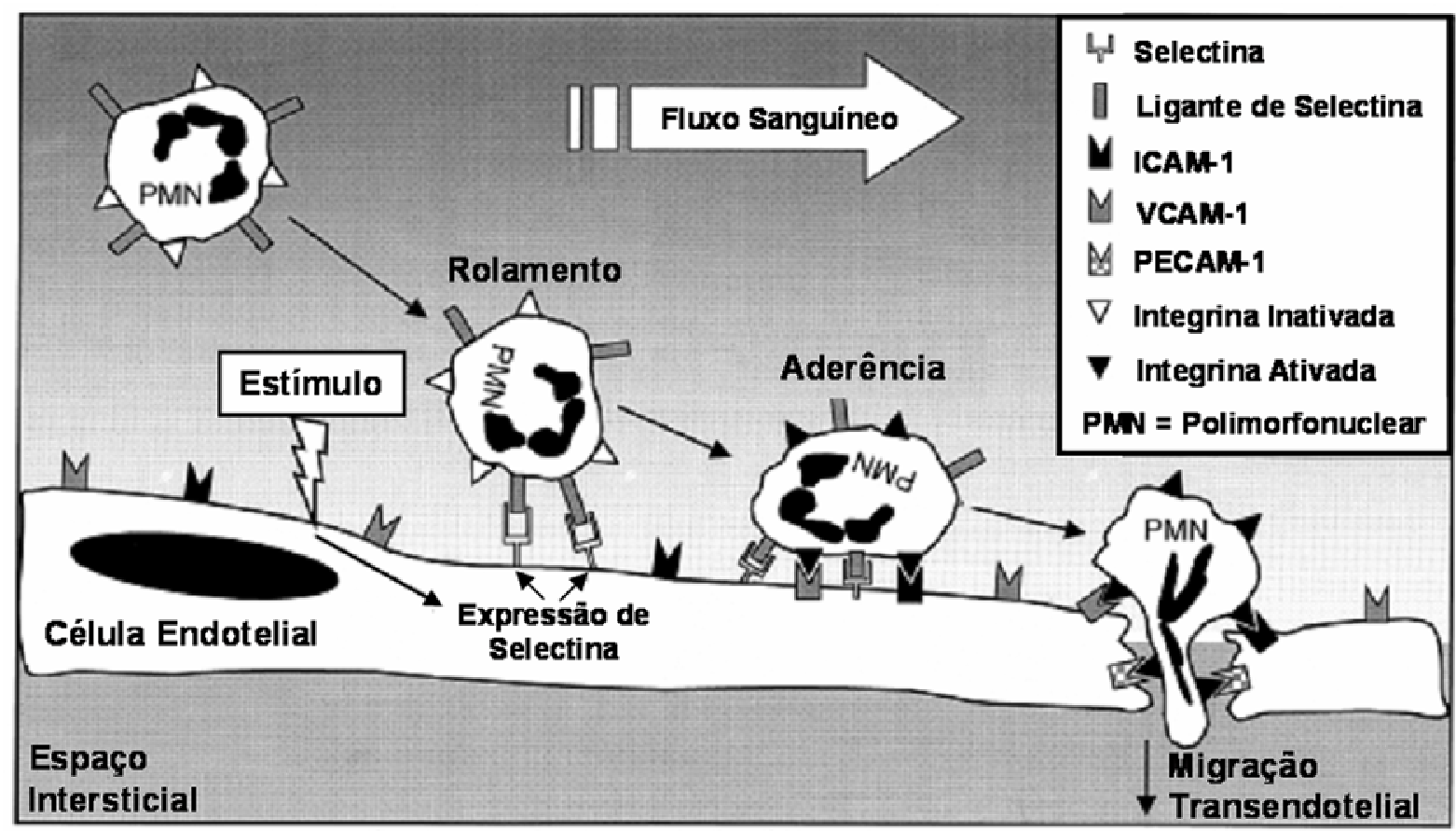

Figura 1 - Modelo representativo do comportamento leucocitário após estímulo inflamatório tecidual local. São três etapas seqüenciais constituintes do recrutamento leucocitário, que geralmente ocorrem de maneira coordenada: rolamento, aderência e migração leucocitária. Moléculas de adesão das famílias das selectinas, integrinas e da superfamília das imunoglobulinas participam ativamente desse processo. ICAM-1: molécula de adesão intercelular-1; VCAM1: molécula de adesão de endotélio vascular-1; PECAM-1: molécula de adesão celular endotelial-plaquetária-1 (KRIEGLSTEIN e GRANGER, 2001). 


\section{MATERIAL E MÉTODOS}

Todos os procedimentos usados neste estudo foram aprovados pela Comissão de Ética em Experimentação Animal (CEEA) do Instituto de Ciências Biomédicas (ICB) da Universidade de São Paulo (USP), estando de acordo com os princípios éticos na experimentação animal adotados pelo Colégio Brasileiro de Experimentação Animal (COBEA).

\subsection{Animais}

Para realização dos experimentos, foram utilizados ratos normotensos (Wistar) e ratos espontaneamente hipertensos (SHR), com 18 semanas de idade, provenientes do Biotério Central do ICB-1/USP. A partir da $8^{\text {a }}$ semana de vida, os animais foram mantidos no Biotério do Laboratório de Hipertensão e Diabetes do Departamento de Farmacologia do ICB-1/USP. Os ratos tiveram livre acesso à água e ração e foram mantidos em sala com temperatura e umidade constantes $\left(24{ }^{\circ} \mathrm{C}\right.$ e $60 \%$, respectivamente), com ciclos claro/escuro de 12/12 horas.

\subsection{Grupos Experimentais}

A escolha dos ratos para cada grupo foi aleatória e em seguida, os mesmos foram comparados entre si, levando-se em consideração massa corpórea e níveis pressóricos, para demonstrar a homogeneidade entre os grupos. Para a realização dos experimentos, foram considerados os seguintes grupos:

- Primeiro Grupo: ratos Wistar intactos (W int);

- Segundo Grupo: ratos SHR intactos (SHR int) e

- Terceiro Grupo: ratos SHR castrados (SHR orx).

\subsection{Procedimento Cirúrgico (Castração)}

A castração foi realizada no momento em que os ratos completaram 12 semanas de idade, período em que os níveis séricos de testosterona atingem concentrações máximas (RECKELHOFF et al., 1998) e que a hipertensão arterial torna-se estável. Os ratos foram anestesiados por injeção intramuscular de Cetamina (167 mg/kg - Cetamin, Syntec) combinada com Xilazina (33 mg/kg - 
Xilazin, Syntec). Atingido o nível cirúrgico, os ratos tiveram os testículos expostos através de uma incisão bilateral da bolsa escrotal para ligadura dos ductos deferentes. Em seguida, os testículos foram removidos e a bolsa escrotal suturada. Após 45 dias de castração os ratos foram submetidos aos diferentes ensaios biológicos.

\subsection{Medida Indireta da Pressão Arterial}

A pressão arterial caudal de ratos não anestesiados foi determinada por método indireto, através de pletismografia de cauda. Antes da primeira medida de pressão arterial, os ratos foram submetidos a um período de adaptação que envolvia tanto o aquecimento dos animais em estufa especial por 10 minutos a $40{ }^{\circ} \mathrm{C}$, quanto a contenção dos mesmos em cilindro de acrílico, com abertura para o focinho e cauda, por um período de dez minutos. Este procedimento foi realizado uma vez ao dia durante dois dias.

Após o período de adaptação, foram determinados os níveis pressóricos dos ratos dos diferentes grupos experimentais. Para isso, os mesmos foram aquecidos por 10 minutos a $40{ }^{\circ} \mathrm{C}$ e colocados no cilindro de contenção. Um oclusor e um sensor foram ajustados na porção proximal da cauda, acoplado ao esfigmomanômetro, e conectados a um sistema de transdução (PowerLab/4S, ADInstruments Pty Ltd, Austrália), respectivamente. O valor final da pressão arterial caudal de cada animal representa a média de três medidas seqüenciais (Figura 2).

\subsection{Determinação do Peso Corpóreo}

Para avaliar se a castração poderia alterar o peso corpóreo dos ratos, os mesmos foram pesados antes (12 semanas de idade) e 45 dias após a cirurgia (antes dos ensaios experimentais).

\subsection{Dosagem de Testosterona}

Amostras de sangue foram coletadas da aorta abdominal dos animais pertencentes aos diferentes grupos experimentais, sendo tal procedimento realizado sempre no mesmo horário (entre 09:00h e 11:00h). O soro, separado por centrifugação a $3.000 \mathrm{rpm}$, por 10 minutos, foi estocado a $-80{ }^{\circ} \mathrm{C}$ em alíquotas para 
dosagem de testosterona. A concentração sérica de testosterona foi determinada por enzima imuno-ensaio (Testosterone EIA Kit, Cayman Chemical CO, USA).

\subsection{Estudo do Comportamento Leucocitário na Microcirculação do Mesentério in vivo in situ}

\subsubsection{Procedimento Cirúrgico e Preparação do Tecido}

Os ratos foram anestesiados com hidrato de cloral $(500 \mathrm{mg} / \mathrm{Kg}$ ) por via subcutânea e após atingirem o nível adequado de anestesia, foi realizada uma incisão longitudinal $(3 \mathrm{~cm})$ na pele e músculo sobre a porção ventro-lateral direita. Posteriormente, o mesentério foi cuidadosamente exposto e colocado sobre uma placa aquecida a $37^{\circ} \mathrm{C}$ por meio de um banho termostatizado (TE-2000, Tecnal, São Paulo, Brasil). Esta placa possuía um centro de acrílico, permitindo assim, a transiluminação (lâmpada de 12 V / 100 W) do tecido, e encontrava-se sobre uma plataforma (Burleigh® Gibraltar) para evitar a possibilidade de vibração.

A preparação foi continuamente superfundida $(2 \mathrm{~mL} / \mathrm{min})$ com solução de

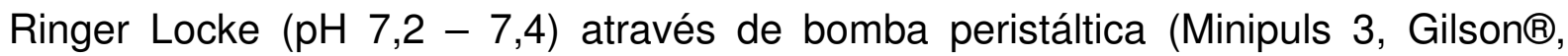
França) com o propósito de evitar o ressecamento do tecido (PANÉS et al., 1999). A composição dessa solução foi (em mM: $154-\mathrm{NaCl} ; 5,6-\mathrm{KCl} ; 2-\mathrm{CaCl}_{2} \cdot 2 \mathrm{H}_{2} \mathrm{O}_{2}$; 6 $\mathrm{NaHCO}_{3}$ e 5-glicose - Merck S/A, Indústria Química, Rio de Janeiro, Brasil) saturada com $95 \%$ de $\mathrm{N}_{2}$ e $5 \%$ de $\mathrm{CO}_{2}$ e a preparação foi mantida úmida e aquecida a $37{ }^{\circ} \mathrm{C}$ durante todo o protocolo experimental (Figura 3).

\subsubsection{Microscopia Intravital}

Após a laparotomia, os microvasos do leito mesentérico foram preparados para a visualização através de microscópio óptico (modelo DM LFS, Leica, Alemanha) acoplado a monitor/televisão LCD de 26", cujo aumento final foi de 1500 vezes (modelo LG 26LX2R, Brasil). As imagens visualizadas foram capturadas por uma câmera digital (modelo DFC300 FX, Leica, Alemanha) acoplada ao microscópio (objetiva de imersão em água, 40 vezes) e digitalizadas para um computador (Pentium D, Intel®), sendo subsequentemente analisadas com auxílio de software apropriado (IM50, Leica, Alemanha) (Figura 3). 


\subsubsection{Protocolo Experimental}

Em uma série experimental, foram realizadas medidas de diâmetro interno $(\mu \mathrm{m})$ das vênulas no leito mesentérico, através de software, considerando-se diâmetro final a média de pelo menos três medidas consecutivas (Figura 4). Após o período de estabilização da preparação (30 minutos), a interação dos leucócitos com a superfície luminal do endotélio venular foi estudada em segmento de vênulas póscapilares com diâmetro interno de 14 a $18 \mu \mathrm{m}$. Os leucócitos que se moveram na periferia do fluxo axial, em contato com o endotélio, foram considerados "rollers" e seu número determinado durante 10 minutos, em segmento de vênula de $100 \mu \mathrm{m}$ (FORTES et al., 1991). Os "rollers" foram avaliados em um determinado ponto de observação (PANÉS et al., 1996) (Figura 5A).

O número de células que aderem ao endotélio foi determinado em uma extensão de $100 \mu \mathrm{m}$ de vênula (Figura 5B). Foram consideradas aderidas, apenas as células que permaneceram fixas ao endotélio venular por mais de 30 segundos (GRANGER et al., 1993), após um intervalo de 10 minutos de estímulo através de superfusão (50 $\mu \mathrm{L} / \mathrm{min})$ com leucotrieno $\mathrm{B}_{4}\left(\mathrm{LTB}_{4}\right.$ - $20 \mathrm{nM}$ - Cayman Chemical CO, USA). A contagem foi realizada também em preparações superfundidas apenas com a solução Ringer Locke para verificar o número de células aderidas sem aplicação do estímulo inflamatório (basal).

Em outra série experimental, o número de leucócitos acumulados em uma área de $2500 \mu \mathrm{m}^{2}$ de tecido conjuntivo, próximo à vênula, foi determinado $4 \mathrm{~h}$ após injeção intraperitoneal de $\mathrm{LTB}_{4}(0,1 \mu \mathrm{M})$ diluído em $5 \mathrm{~mL}$ de Ringer Locke. Imediatamente após a exposição do tecido, as áreas foram escolhidas e gravadas através do software (IM50, Leica, Alemanha) para análise do número de células migradas, que corresponderam à média das células obtidas a partir de imagens captadas de pelo menos três campos distintos (Figura 5C). O mesmo procedimento foi realizado nos grupos experimentais apenas com a solução nutriente para verificar o número de células migradas na ausência do estímulo inflamatório (basal).

Ao final dos experimentos, as preparações foram coradas com azul de toluidina (0,1\% - ECIBRA Equipamentos Científicos do Brasil S/A) por 5 minutos, para verificação da desgranulação dos mastócitos, que indica o grau de injúria 
provocado pela manipulação da preparação. Após o término de cada experimento, os ratos foram sacrificados por excesso de anestésico (Figura 6).

\subsection{Velocidade do Fluxo Sanguíneo e Taxa de Atrito Venular}

Em uma terceira série experimental, a velocidade do fluxo sanguíneo foi analizada utilizando-se velocímetro óptico (Optical Doppler Velocimeter Microcirculation Research Institute, Texas A \& M University, College Station, Texas, USA, 77843), acoplado ao microscópio óptico (modelo DM LFS, Leica, Alemanha), com objetiva de 20 vezes. O velocímetro foi calibrado por rotação do disco de vidro contra o fluxo das hemácias. A velocidade média das hemácias $\left(V_{\text {mean }}\right)$ foi considerada igual a $\mathrm{V}_{\mathrm{RBC}}$ - red blood cell velocity $(\mathrm{mm} / \mathrm{seg})$ para vasos com diâmetro até $25 \mu \mathrm{m}$ (BORDERS e GRANGER, 1984). Assim, calculou-se a taxa de atrito $\operatorname{venular}(\gamma)$ determinada pela definição Newtoniana $\gamma=8$. $\left(V_{\text {mean }} / D_{v}\right)$, sendo $D_{v}=$ diâmetro venular (HOUSE e LIPOWSKY, 1987). Foram utilizadas vênulas póscapilares do mesentério cujo diâmetro interno variou de 14 a $18 \mu \mathrm{m}$ (Figura 7).

\subsection{Leucogramas Total e Diferencial}

Ratos não-anestesiados foram mantidos em contensores com abertura para focinho e cauda. Após o aquecimento da cauda durante 30 segundos, à temperatura de $40{ }^{\circ} \mathrm{C}$, precedeu-se o corte da extremidade da mesma $(0,5 \mathrm{~cm}$ de distância da ponta da cauda) e o sangue foi coletado, desprezando-se as três primeiras gotas. Tal procedimento foi realizado sempre no mesmo horário (entre 09:00h e 11:00h). As amostras de sangue foram colocadas em tubos contendo $K_{2}$ EDTA (BD Vacutainer, Minas Gerais, Brasil) e suavemente homogeneizadas. Em seguida, foram diluídas na proporção de 1:20 (vol:vol) com liquído de Turk e novamente homogeneizadas. A contagem do número total de leucócitos foi realizada em câmara de Neubauer. Para a contagem diferencial de leucócitos, foram realizados esfregaços sanguíneos, os quais foram fixados em lâminas e corados com kit Instant-Prov $^{\circledR}$ (Newprov, Paraná, Brasil). A contagem de linfócitos, neutrófilos, monócitos e eosinófilos foi realizada em microscópio óptico, com objetiva de imersão (aumento de 100 vezes). 


\subsection{Determinação da Expressão Protéica de P-selectina e ICAM-1 em Vênulas Mesentéricas por Imunohistoquímica}

\subsubsection{Obtenção do Material}

Os animais foram anestesiados com tiopental sódico $(50 \mathrm{mg} / \mathrm{kg}$ de peso corporal, i.p.) e após laparotomia, o mesentério foi cuidadosamente exposto. A artéria mesentérica superior foi cateterizada com tubo de polietileno (PE-10 Hemo Técnico® - São Paulo, Brasil) introduzido cerca de 1,5 a 2,0 cm distante da aorta abdominal e o leito mesentérico foi perfundido com solução fisiológica 0,9\%, com fluxo constante de $2 \mathrm{~mL} / \mathrm{min}$ durante 3 minutos, e em seguida, com solução fixadora paraformaldeído 4\% (PFA) por 15 minutos. Após este procedimento, o mesentério foi removido do rato e em seguida realizou-se a retirada das vênulas mesentéricas, juntamente com o tecido conectivo e adiposo, as quais foram imediatamente colocadas em solução de PFA por 6h. Após a fixação, as vênulas foram crioprotegidas em solução de sacarose $30 \%$ e em seguida emblocadas em meio para congelamento (Leica Instruments), e mantidas a $-80{ }^{\circ} \mathrm{C}$ até a realização dos cortes. Para garantir que os cortes utilizados abrangessem uma porção significativa da vênula, foram feitos dez cortes não seriados de $14 \mu \mathrm{m}$ de espessura em criostato Leica CM 1850 (Leica Instruments, North Ryde, NSW, Austrália) a -25 ${ }^{\circ} \mathrm{C}$ e estes foram colocados em lâminas silanizadas. Após esse procedimento os cortes foram armazenados em freezer $\left(-20^{\circ} \mathrm{C}\right)$ para posterior análise.

\subsubsection{Imunohistoquímica}

Para o estudo de imunohistoquímica foram utilizados os seguintes anticorpos: anticorpo monoclonal ICAM-1, conjugado com biotina (BD-Pharmingen, Califórnia, EUA) e o anticorpo policlonal P-selectina (BD-Pharmingen).

As lâminas referidas no item 2.10.1 foram lavadas em tampão de fosfato salina (PBS) 0,1 M durante 5 minutos e em seguida os cortes foram incubados com os anticorpos, diluídos em PBS 0,1 M com Tween 20 a 0,3\% na proporção 1:10 para anti-ICAM-1 e 1:100 para anti-P-selectina, por um período de $18 \mathrm{~h}$ a $4{ }^{\circ} \mathrm{C}$ em câmara úmida. As reações controle foram realizadas substituindo-se o anticorpo primário por 
PBS 0,1 M com Tween 20 a 0,3\% [controle negativo (CN)]. Após o período de incubação, as lâminas foram lavadas três vezes a cada 5 minutos em PBS 0,1 M.

No caso da reação para determinação da P-selectina, os cortes foram incubados com anticorpo secundário conjugado com biotina (anti-rabbit 1:1000 em PBS 0,1 M com Tween 20 a 0,3\% - Kit ABC Vectastain, Vector Laboratories, Califórnia, EUA) durante $2 \mathrm{~h}$ em temperatura ambiente dentro de câmara úmida. Seguiu-se lavagem, três vezes por 5 minutos cada, em PBS 0,1 M.

Em seguida, os cortes foram incubados em solução de avidina/biotina (diluída em PBS 0,1 M com Tween 20 a 0,3\% na proporção de 1:100 para A e 1:100 para $B$ - Kit ABC Vectastain) por 1h em temperatura ambiente e câmara úmida. Após esse período, os cortes foram novamente lavados três vezes durante 5 minutos cada em PBS $0,1 \mathrm{M}$.

Posteriormente, foi realizada a reação com diaminobenzidina $(0,5 \mathrm{mg} / \mathrm{mL}$ DAB; Sigma-Aldrich, Missouri, EUA) na presença de peróxido de hidrogênio (3 $\mu \mathrm{L} / \mathrm{mL}$ ) diluídos em PBS 0,1 M, durante os seguintes tempos: 50 segundos para ICAM-1 e 1 minuto para P-selectina. Seguiu-se lavagem das lâminas duas vezes em PBS 0,1 M e uma vez em água destilada, durante 3 minutos cada. Após a secagem das lâminas, as mesmas foram montadas utilizando-se lamínulas e Entellan (Merck, Darmstadt, Alemanha) para posterior observação ao microscópio.

Foi realizada, então, análise comparativa e quantificação de P-selectina e ICAM-1 por densidade de imagens em "software" (KS300, para microscópio E-800 da Nikon), sendo os resultados expressos em unidades arbitrárias.

\subsection{Determinação da Expressão de RNAm de ICAM-1, VCAM-1 e PECAM-1 no Leito Mesentérico}

2.11.1 Obtenção do RNAm, Reação de RT (Transcriptase Reversa) e PCR (Reação de Polimerase em Cadeia) em Tempo Real

Os ratos foram anestesiados com tiopental sódico $(50 \mathrm{mg} / \mathrm{kg}$ de peso corporal, i.p.) e ao atingirem o nível cirúrgico, foram submetidos a laparotomia e tiveram o mesentério cuidadosamente retirado. Vênulas, juntamente com arteríolas mesentéricas, foram rapidamente dissecadas, congeladas em nitrogênio líquido e armazenadas a $-80{ }^{\circ} \mathrm{C}$. O RNA celular total foi isolado utilizando o reagente Trizol 
(Invitrogen Co., USA), seguindo as orientações do fabricante. Foi utilizado DNase I para digerir o DNA que ocasionalmente pudesse estar presente na amostra de RNA após o processo de extração. Foi realizada a síntese da fita simples de cDNA reação de transcrição reversa (RT) - a partir de $2 \mu \mathrm{g}$ do RNA total, utilizando a enzima SuperScript II, e a RNaseOUT foi adicionada para proteger o RNA durante esse processo. A amplificação do cDNA foi realizada usando os seguintes "primers": 5'-CCT CTT GCG AAG ACG AGA AC-3'(sense) e 5'-ACT CGC TCT GGG AAC GAA TA -3'(anti-sense) (198 pb) para ICAM-1; 5'-AAG GGG CTA CAT CCA CAC TG -3' (sense) e 5'-ACC GTG CAG TTG ACA GTG AC-3'(anti-sense) (195) para VCAM-1 de rato; 5'- GAA GGT TTC TGA GCC CAG TG-3'(sense) e 5'-TCA AGG GAG GAC ACT TCC AC-3'(anti-sense) (93 pb) para PECAM-1; 5'-AAG ATT TGG CAC CAC ACT TTC TAC A-3'(sense) e 5'-CGG TGA GCA GCA CAG GGT-3'(antisense) (69 pb) para $\beta$-actina de rato.

A quantidade de cDNA específica para cada gene foi analisada por PCR em tempo real utilizando o reagente Platinum SYBR green qPCR SuperMix UDG (Invitrogen). As reações de PCR foram realizadas e analisadas usando o sistema Corbett Research (Corbett Life Sciences, Austrália).

As condições do PCR foram: 2 minutos a $50{ }^{\circ} \mathrm{C}, 2$ minutos a $95{ }^{\circ} \mathrm{C}$ seguindo-se 40 ciclos na seguinte seqüência: $95{ }^{\circ} \mathrm{C}$ por 15 segundos, $60{ }^{\circ} \mathrm{C}$ por 1 minuto e $72{ }^{\circ} \mathrm{C}$ por 20 segundos. A especificidade da reação com SYBR green foi confirmada pela análise da curva de dissociação tomando como base a temperatura de dissociação - "melting point". A expressão gênica foi quantificada utilizando o cálculo do Ct "cycle threshold" (PFAFFL, 2001). Os resultados da expressão da $\beta$ actina foram utilizados para normalização. Os resultados foram expressos em unidades arbitrárias relativas à variação da expressão de RNAm.

\subsection{Análise Estatística}

Os resultados foram expressos como média \pm erro padrão da média (epm). As análises estatísticas foram realizadas utilizando-se análise de variância de uma via (ANOVA) seguido do teste de Bartlett para a homogeneidade das variâncias e teste de múltiplas comparações Tukey-Kramer, quando pertinente. O nível de significância mínima aceitável foi $p<0,05$. 


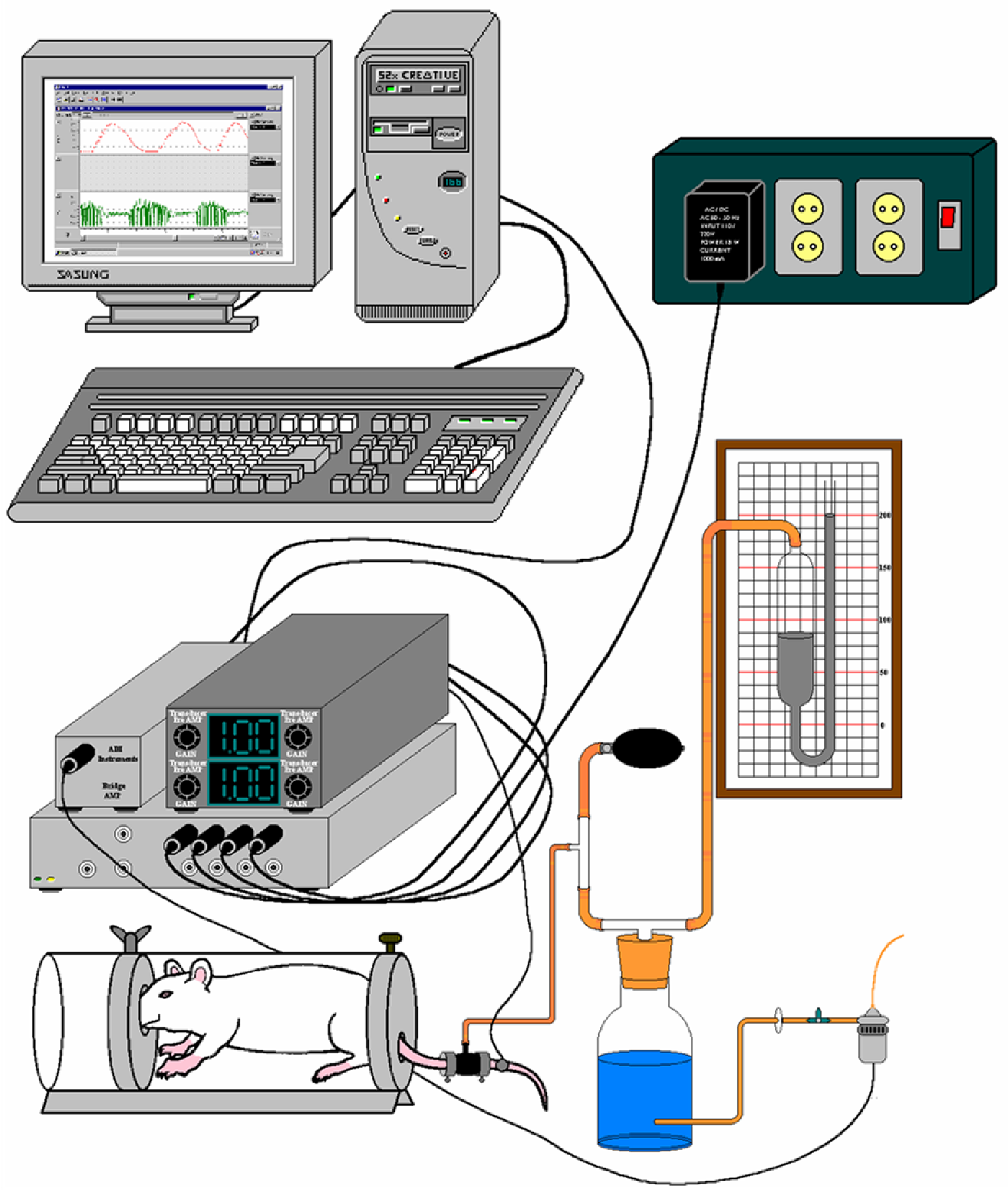

Figura 2 - Sistema de medida de pressão arterial indireta (Método de Pletismografia de Cauda). 


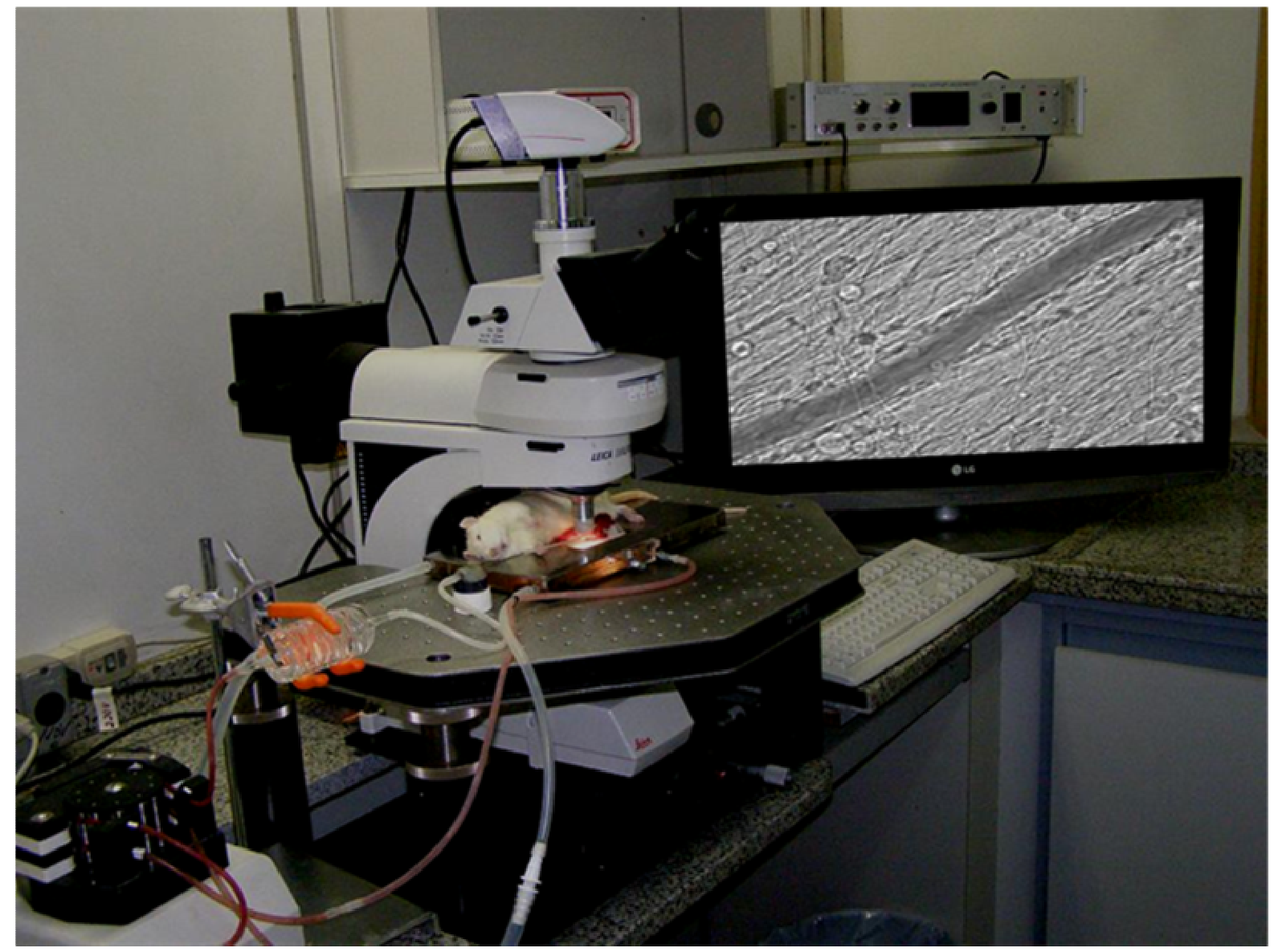

Figura 3 - Representação do sistema de microscopia intravital, constituído da placa aquecedora mantida a $37{ }^{\circ} \mathrm{C}$ através do banho termostatizado. Esta placa possui uma região central de acrílico para a transiluminação do tecido. Outros componentes do sistema incluem a câmera acoplada ao microscópio óptico, que permite a visualização da imagem na tela da televisão através do computador. 


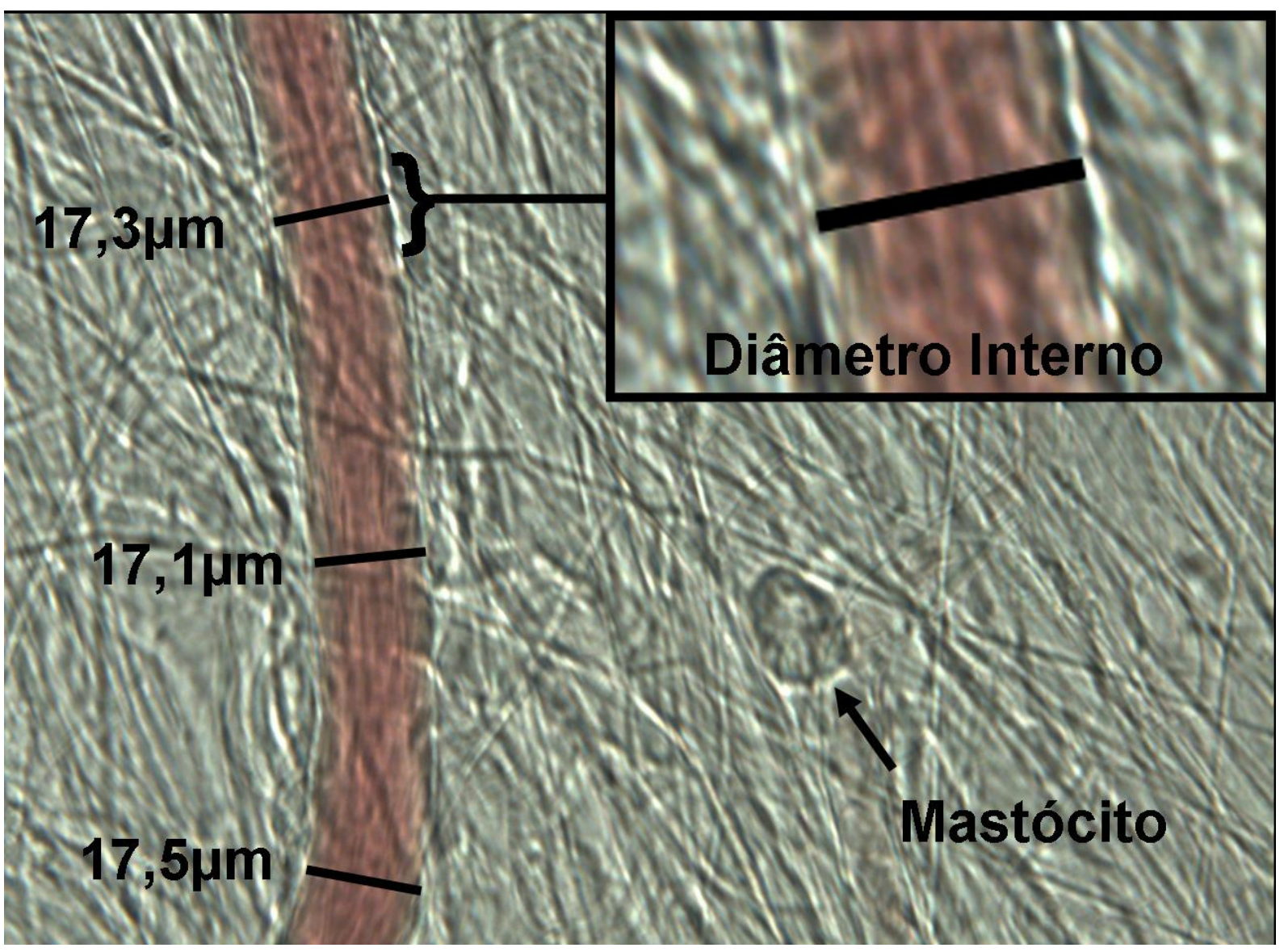

Figura 4 - Vênula pós-capilar do leito mesentérico de rato, superfundido com solução nutriente (Ringer Locke) e observado em microscopia intravital. Medida do diâmetro interno venular (no canto superior à direita, detalhe da parede interna). O valor do diâmetro venular é calculado a partir da média de três valores obtidos em pontos distintos do microvaso (por exemplo: $D_{v}=17,3 \mu \mathrm{m}$ ). 


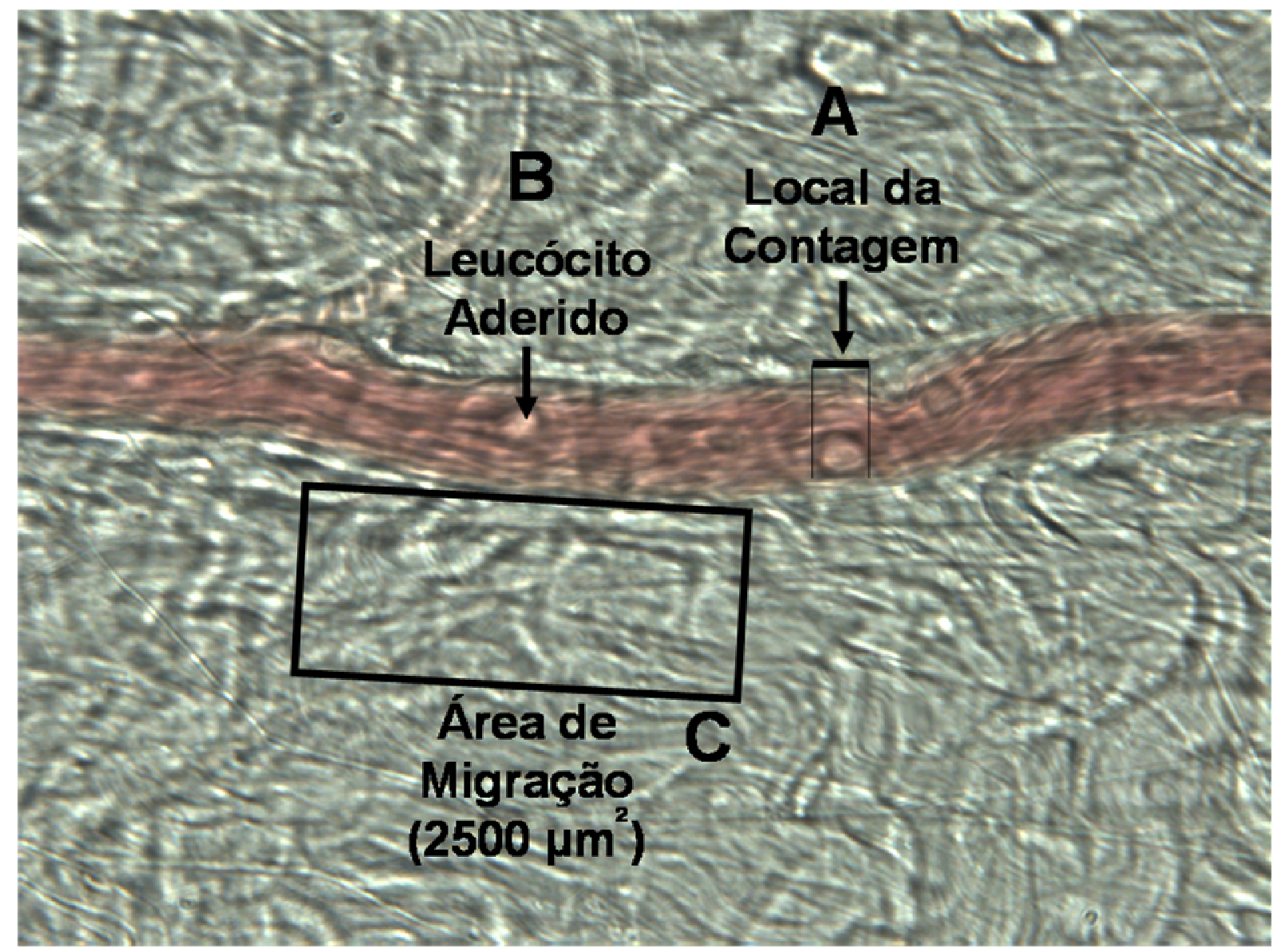

Figura 5 - Vênula pós-capilar do leito mesentérico de rato superfundido com solução de Ringer Locke e observado em microscopia intravital. (A) Local de contagem de rolamento dos leucócitos; (B) Leucócitos aderidos ao longo de $100 \mu \mathrm{m}$ de comprimento da vênula; (C) Área correspondente a contagem das células que migraram sob estímulo com $\mathrm{LTB}_{4}$. 


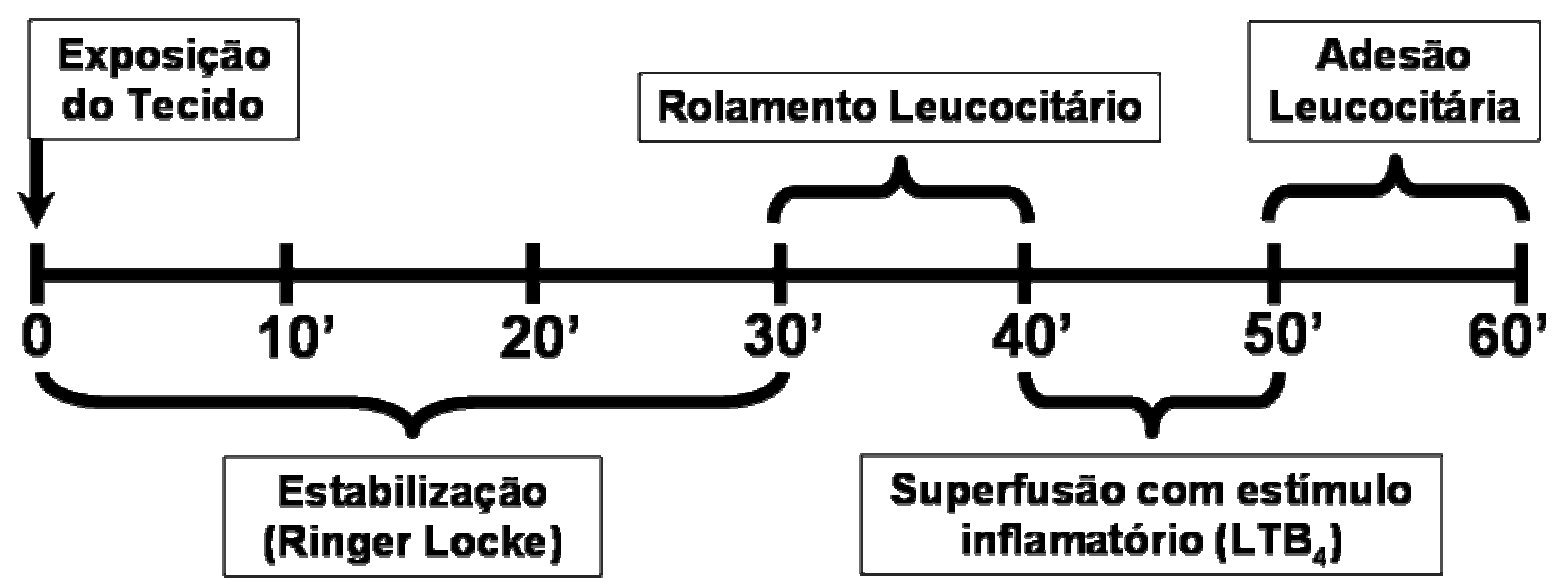

Figura 6 - Protocolo experimental do comportamento leucocitário. 


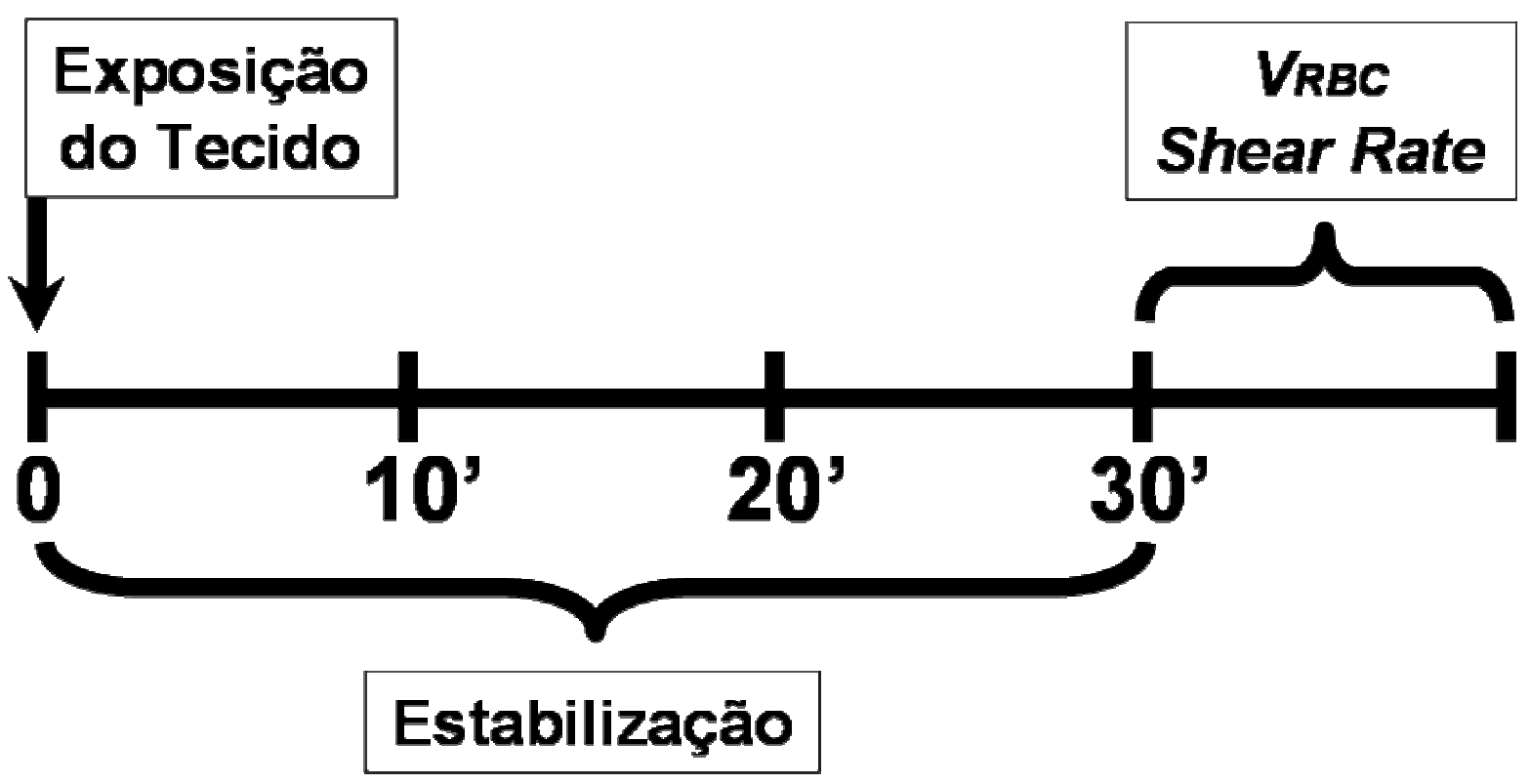

Figura 7 - Protocolo experimental da velocidade do fluxo sanguíneo. 


\section{RESULTADOS}

\subsection{Pressão Arterial Indireta}

Animais pertencentes ao grupo SHR int apresentaram pressão arterial aumentada quando comparados aos controles normotensos $W$ int $(195,2 \pm 2,8$ $\mathrm{mmHg}$ vs $121,5 \pm 1,1 \mathrm{mmHg} ; \mathrm{p}<0,001$, respectivamente). O grupo SHR orx apresentou redução significativa na pressão arterial caudal quando comparado aos SHR int, entretanto esses valores permaneceram maiores do que aqueles do grupo $\mathrm{W}$ int $(171,3 \pm 2,0 \mathrm{mmHg}$ vs $121,5 \pm 1,1 \mathrm{mmHg} ; \mathrm{p}<0,001$, respectivamente) (Figura 8).

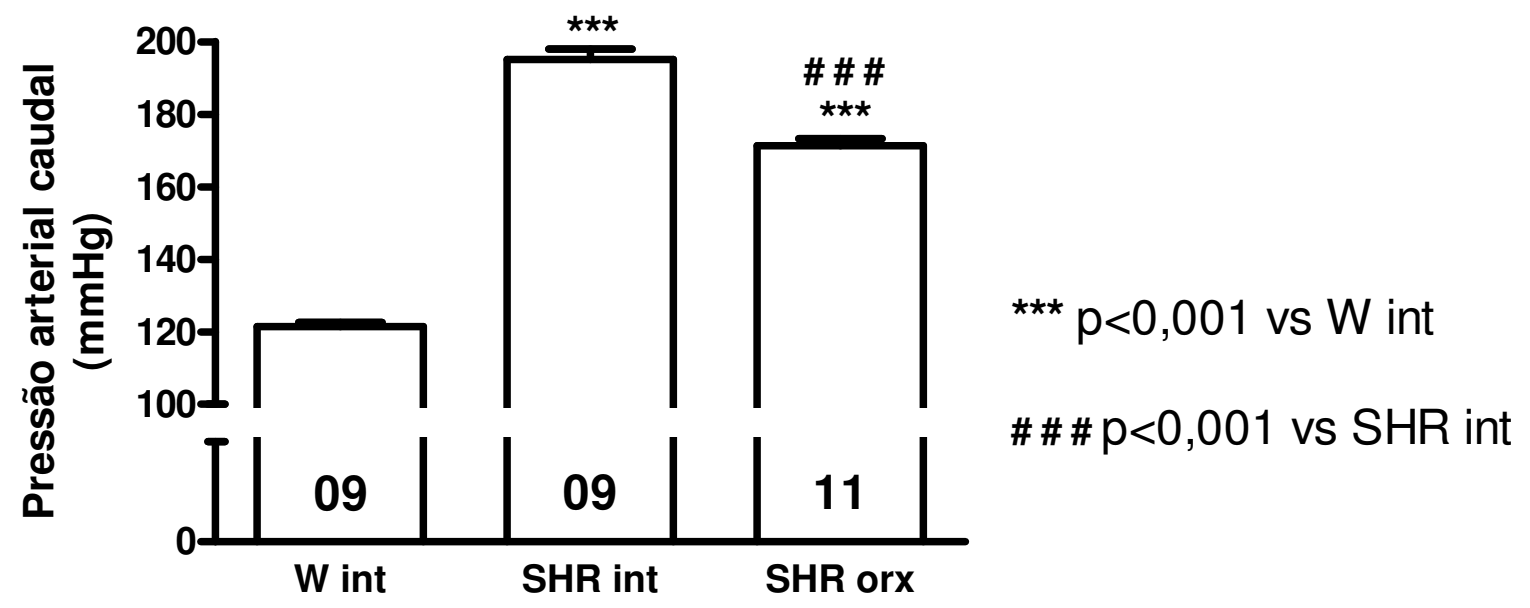

Figura 8 - Pressão arterial caudal de ratos pertencentes aos grupos SHR intacto (SHR int) e castrado (SHR orx) e do respectivo grupo normotenso (W int). Cada barra representa a média \pm EPM. O número de ratos utilizados em cada grupo encontra-se no interior das barras. 


\subsection{Massa Corpórea}

A massa corpórea dos ratos pertencentes aos grupos SHR int e W int do presente estudo foi estatisticamente semelhante $(303,0 \pm 6,1 \mathrm{~g}$ vs 325,0 \pm 8,9 g; respectivamente). A castração não interferiu neste parâmetro $(317,7 \pm 7,4 \mathrm{~g})$ (Figura 9).

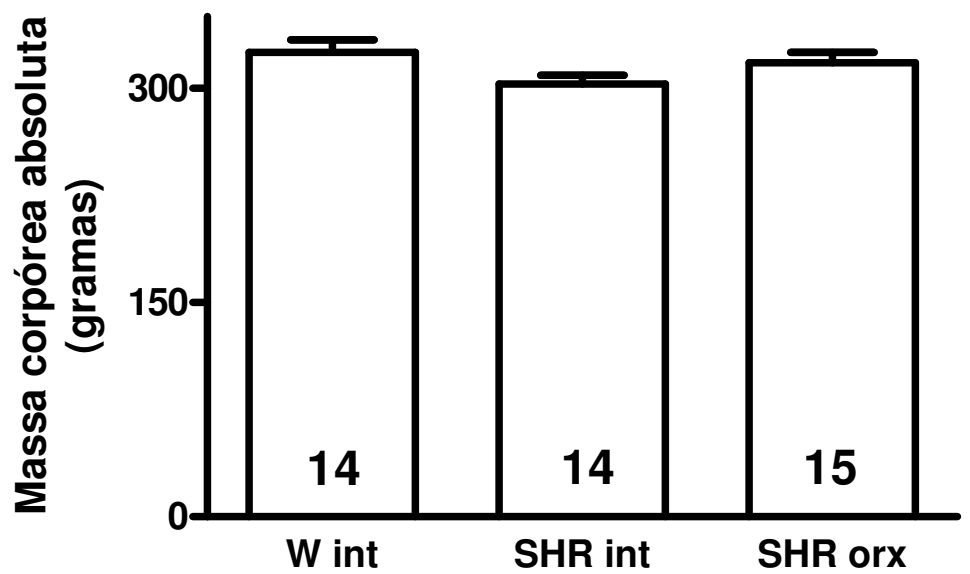

Figura 9 - Massa corpórea de ratos pertencentes aos grupos SHR intacto (SHR int) e castrado (SHR orx) e do respectivo grupo normotenso (W int). Cada barra representa a média \pm EPM. $O$ número de ratos utilizados em cada grupo encontra-se no interior das barras. 


\subsection{Dosagem de Testosterona}

Os animais do grupo SHR int apresentaram concentrações séricas de testosterona significativamente maior quando comparados ao grupo $W$ int $(511,6 \pm$ $26,5 \mathrm{pg} / \mathrm{mL}$ vs $270,5 \pm 27,0 \mathrm{pg} / \mathrm{mL} ; \mathrm{p}<0,001$, respectivamente). A castração foi eficaz em promover redução nos níveis deste hormônio no grupo SHR orx $(17,2 \pm 2,4$ $\mathrm{pg} / \mathrm{mL}$ ) (Figura 10).

Observação: Vale ressaltar que o valor da concentração de testosterona do grupo SHR int foi subestimada, uma vez que 67\% das amostras tiveram valores acima da curva padrão.

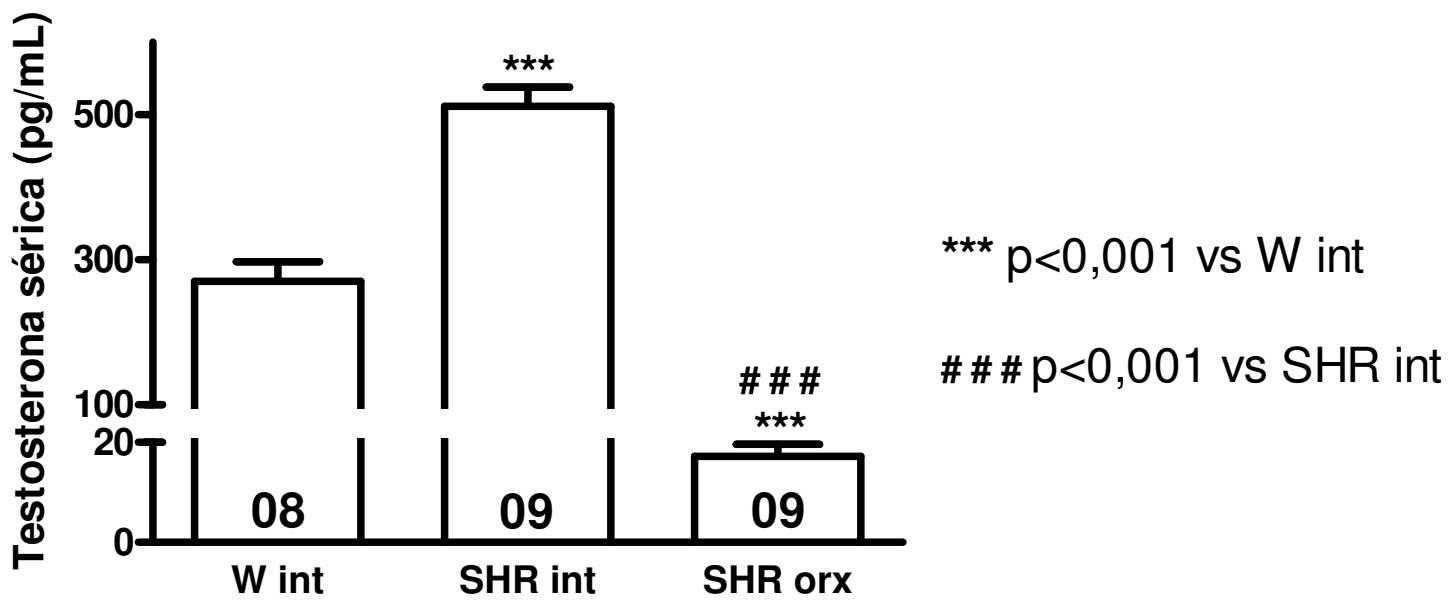

Figura 10 - Concentração sérica de testosterona de ratos pertencentes aos grupos SHR intacto (SHR int) e castrado (SHR orx) e do respectivo grupo normotenso (W int). Cada barra representa a média \pm EPM. O número de ratos utilizados em cada grupo encontra-se no interior das barras. 


\subsection{Rolamento Leucocitário}

O grupo SHR int apresentou aumento significativo do número de leucócitos rolando na superfície endotelial de vênulas pós-capilares do mesentério, contados durante o intervalo de dez minutos, quando comparado ao grupo $W$ int (136 \pm 6 células vs $94 \pm 6$ células; $p<0,001$, respectivamente). A castração dos ratos hipertensos reduziu significativamente o número de leucócitos rolando para valores semelhantes (111 \pm 3 células) àqueles encontrados no grupo W int (Figura 11).

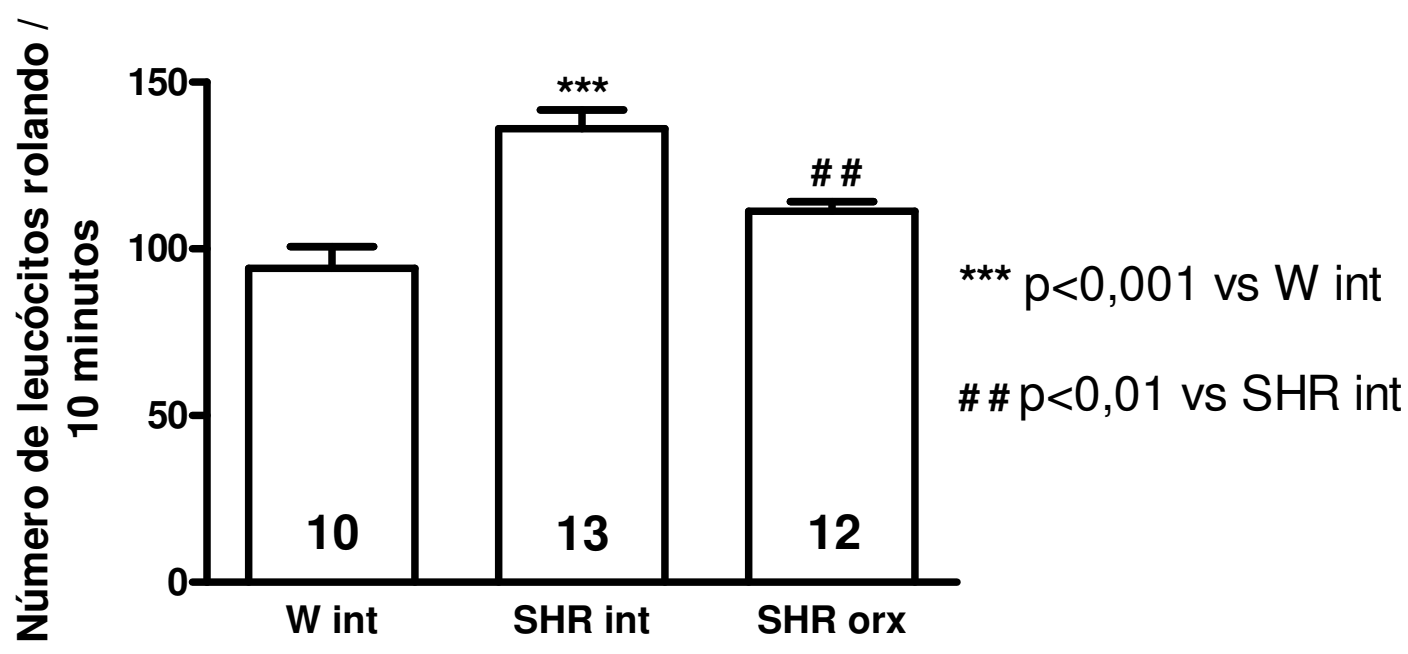

Figura 11 - Medida do número de leucócitos rolando durante o intervalo de dez minutos, determinado em vênulas pós-capilares do leito mesentérico de ratos dos grupos: SHR intacto (SHR int), SHR castrado (SHR orx) e do respectivo grupo normotenso (W int). Essa medida foi realizada após o período de 30 minutos de estabilização da preparação. Cada barra representa a média \pm EPM. O número de ratos utilizados em cada grupo encontra-se no interior das barras. 


\subsection{Aderência Leucocitária}

Não houve diferença no número de células aderidas entre os grupos estudados sob condição basal. $\mathrm{O} \mathrm{LTB}_{4}$ foi efetivo em promover aderência leucocitária, sendo que o grupo SHR int apresentou aumento significativo no número de leucócitos aderidos ao endotélio de vênulas pós-capilares mesentéricas após superfusão do estímulo quimiotáxico pelo período de 10 minutos, quando comparado ao grupo $W$ int ( $12 \pm 1$ células vs $8 \pm 1$ células; $p<0,5$, respectivamente). A castração reverteu o aumento do número de leucócitos aderidos no grupo SHR orx para nível semelhante ao encontrado no grupo $W$ int ( $9 \pm 1$ células vs $8 \pm 1$ células; respectivamente) (Figura 12).

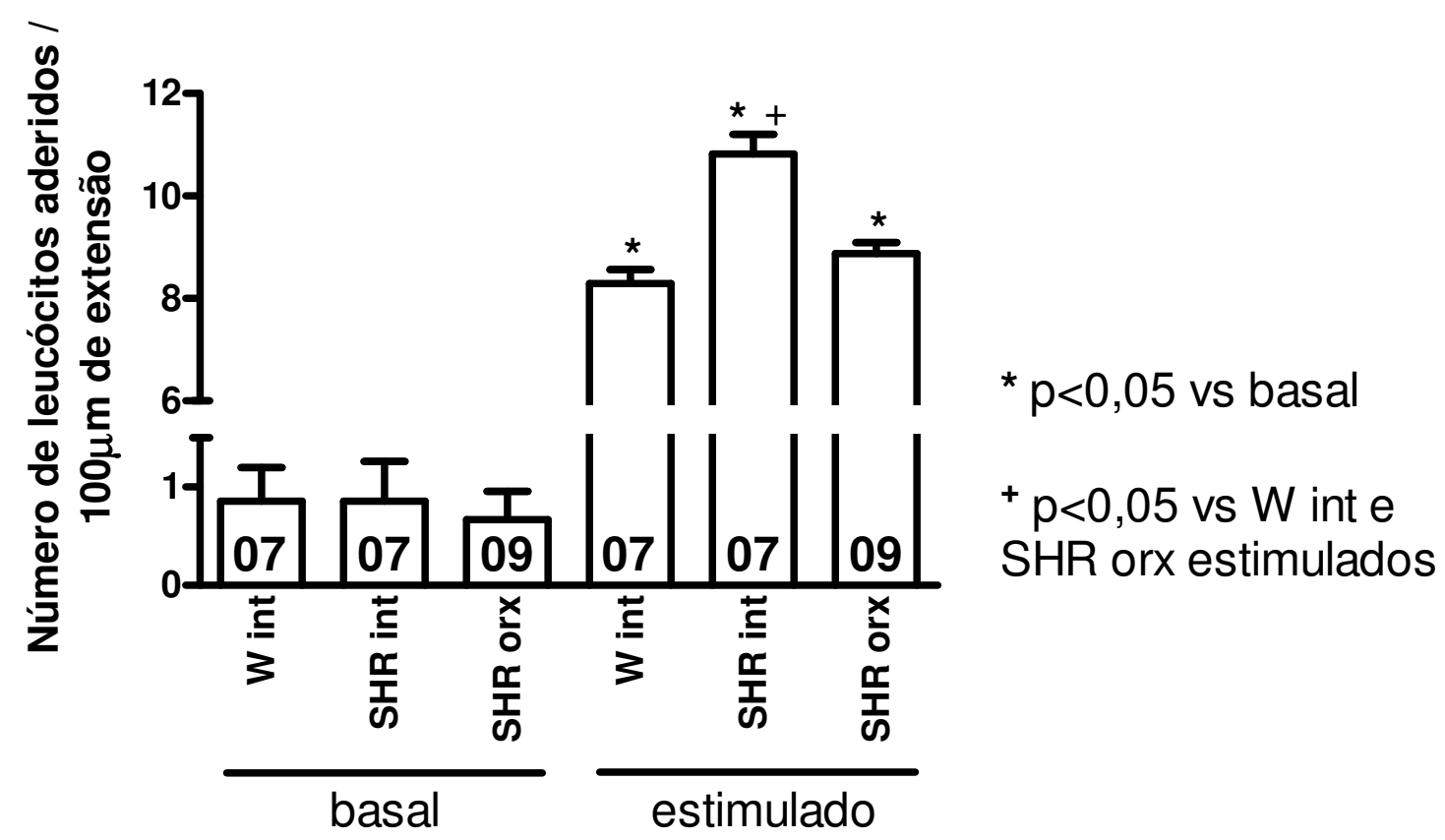

Figura 12 - Aderência leucocitária determinada em $100 \mu \mathrm{m}$ de extensão de vênulas póscapilares do leito mesentérico de ratos dos grupos: SHR intacto (SHR int), castrado (SHR orx) e do respectivo grupo normotenso (W int), antes (basal) e após 10 minutos de superfusão com $\mathrm{LTB}_{4}$ [20 nM, $50 \mu \mathrm{L} /$ min (estimulado)]. Cada barra representa a média $\pm E P M$. $O$ número de ratos utilizados em cada grupo encontra-se no interior das barras. 


\subsection{Migração Leucocitária}

Com o intuito de avaliarmos a interferência da solução nutriente na ausência do $\mathrm{LTB}_{4}$, realizamos o mesmo procedimento apenas com a aplicação da solução nutriente, e verificamos que esta não interferiu na migração leucocitária (basal). $O$ estímulo inflamatório induzido por injeção intraperitoneal da solução de $\operatorname{LTB}_{4}(0,1$ $\mu \mathrm{M} / 5 \mathrm{~mL}$ ) foi eficaz em promover migração transendotelial das células leucocitárias (Figura 13, estimulado) quando comparada com os níveis basais. O número de leucócitos migrados observados na preparação mesentérica dos ratos pertencentes aos grupos SHR int e W int do presente estudo foi estatisticamente semelhante (9 \pm 1 células vs $10 \pm 1$ células; respectivamente). A castração não interferiu neste parâmetro (10 \pm 1 células) (Figura 13).

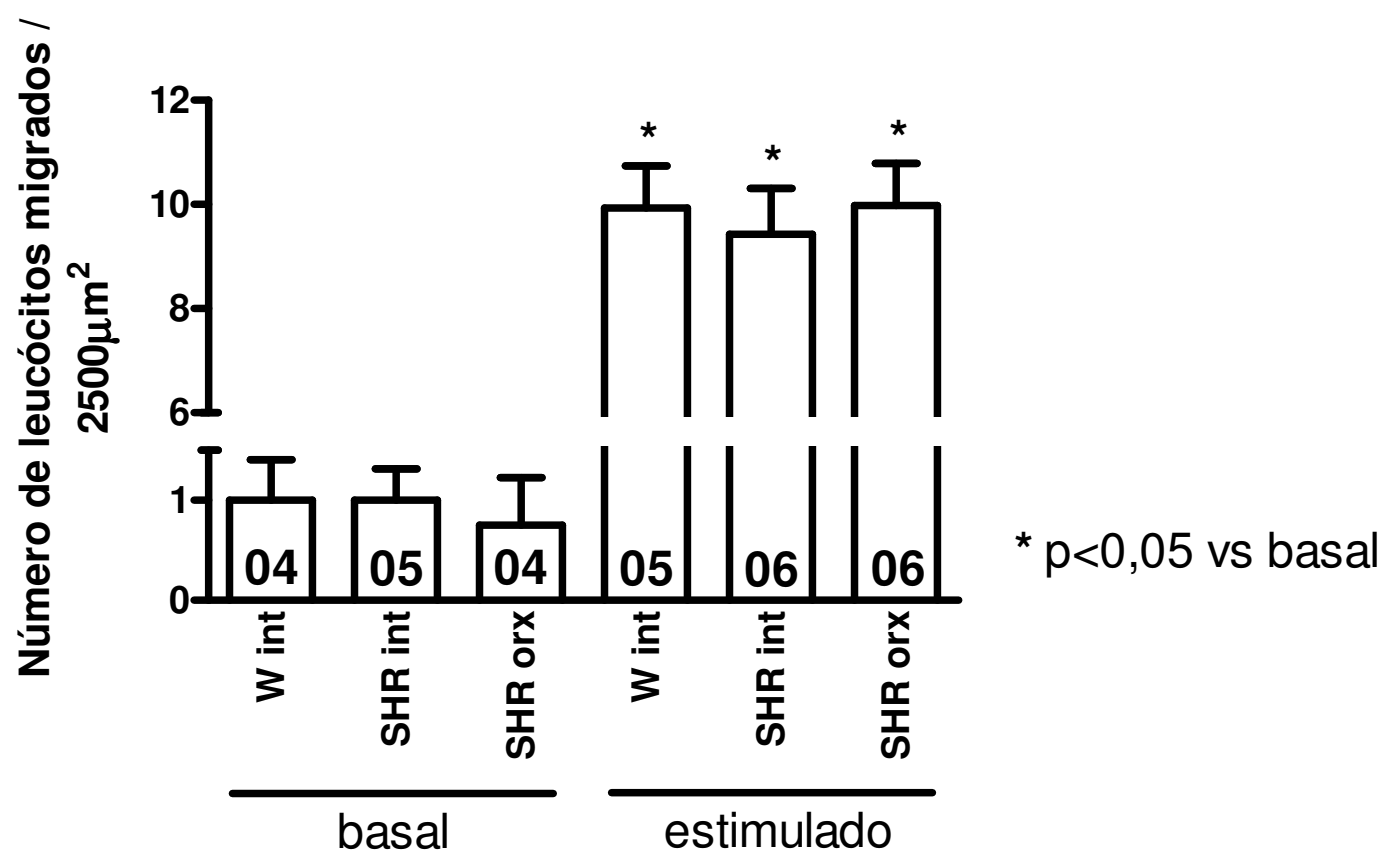

Figura 13 - Migração leucocitária determinada em $2500 \mu \mathrm{m}^{2}$ de área próxima a vênulas pós-capilares presentes no leito mesentérico de ratos pertencentes aos grupos SHR intacto (SHR int) e castrado (SHR orx) e do respectivo grupo normotenso (W int) quatro horas após injeção intraperitoneal com $\operatorname{LTB}_{4}(0,1 \mu \mathrm{M} / 5 \mathrm{~mL})-$ estimulado, e após injeção da solução nutriente (Ringer Locke) - basal. Cada barra representa a média \pm EPM. O número de ratos utilizados em cada grupo encontra-se no interior das barras. 


\subsection{Diâmetro Venular}

O diâmetro das vênulas presentes no mesentério dos animais do grupo SHR int foi semelhante ao do grupo $W$ int, tanto em condições basais $(17,2 \pm 0,3 \mu \mathrm{m}$ vs $16,9 \pm 0,5 \mu \mathrm{m}$; respectivamente) quanto após estímulo com $\operatorname{LTB}_{4}(18,1 \pm 0,3 \mu \mathrm{m}$ vs 17,0 \pm 0,2 $\mu \mathrm{m})$. A castração não alterou o diâmetro venular dos animais do grupo SHR orx nestas duas condições (Figura 14).

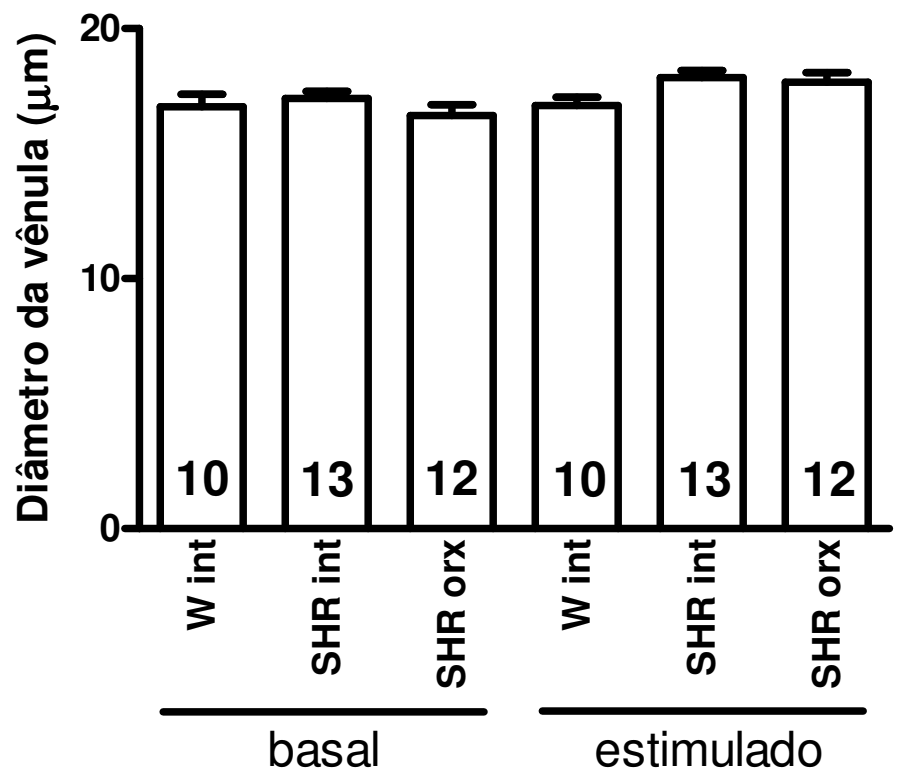

Figura 14 - Diâmetro de vênulas pós-capilares do leito mesentérico, avaliado sub condição basal e estimulada $\left(\mathrm{LTB}_{4}\right)$, de ratos pertencentes aos grupos SHR intacto (SHR int) e castrado (SHR orx) e do respectivo grupo normotenso (W int). Cada barra representa a média \pm EPM. $O$ número de ratos utilizados em cada grupo encontra-se no interior das barras. 


\subsection{Velocidade do Fluxo Sanguíneo}

Não houve diferença estatística na velocidade do fluxo sanguíneo em vênulas pós-capilares do leito mesentérico de ratos do grupo SHR int e W int $(1,8 \pm$ $0,04 \mathrm{~mm} / \mathrm{s}$ vs $1,7 \pm 0,10 \mathrm{~mm} / \mathrm{s}$; respectivamente). A castração dos animais do grupo SHR orx não alterou este parâmetro (1,7 $\pm 0,06 \mathrm{~mm} / \mathrm{s})$ (Figura 15).

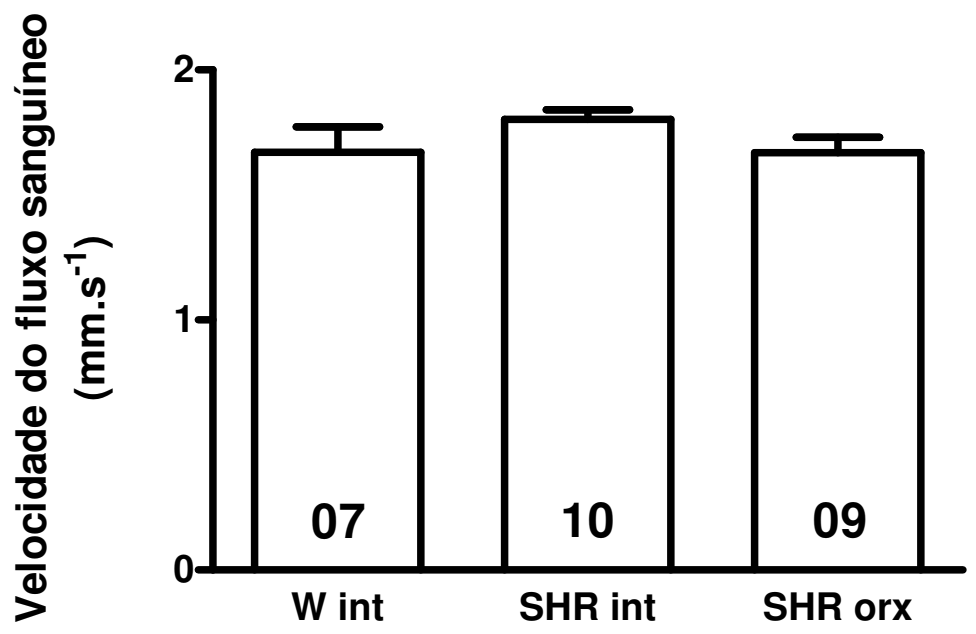

Figura 15 - Velocidade do fluxo sanguíneo determinado em vênulas pós-capilares do leito mesentérico de ratos pertencentes aos grupos SHR intacto (SHR int) e castrado (SHR orx) e do respectivo grupo normotenso (W int). Cada barra representa a média \pm EPM. O número de ratos utilizados em cada grupo encontra-se no interior das barras. 


\subsection{Taxa de Atrito Venular}

Não houve diferença estatística no cálculo da taxa de atrito avaliada em vênulas pós-capilares do leito mesentérico de ratos do grupo SHR int e Wistar int (792,5 $\pm 28,3 \mathrm{~s}^{-1}$ vs $721,4 \pm 22,5 \mathrm{~s}^{-1}$, respectivamente). Os ratos pertencentes ao grupo SHR orx tiveram os valores deste parâmetro inalterados quando comparados com os demais grupos $\left(764,7 \pm 24,7 \mathrm{~s}^{-1}\right)$ (Figura 16).

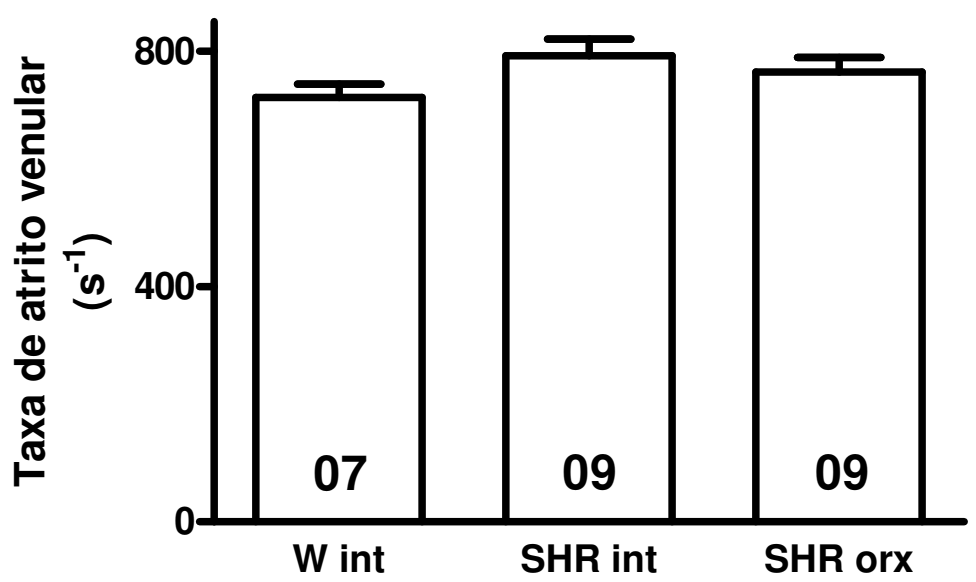

Figura 16 - Cálculo da taxa de atrito em vênulas pós-capilares do leito mesentérico de ratos pertencentes aos grupos SHR intacto (SHR int) e castrado (SHR orx) e do respectivo grupo normotenso ( $\mathrm{W}$ int). Cada barra representa a média \pm EPM. $\mathrm{O}$ número de ratos utilizados em cada grupo encontra-se no interior das barras. 


\subsection{Leucogramas Total e Diferencial}

A contagem total de leucócitos circulantes não foi diferente entre o grupo SHR int e o grupo W int. A castração não modificou o número de leucócitos totais quando comparado aos demais grupos. Resultado semelhante foi observado na análise do leucograma diferencial (Tabela 2).

Tabela 2 - Número de leucócitos total e diferencial (linfócitos, neutrófilos, eosinófilos e monócitos) coletados da cauda de ratos não-anestesiados pertencentes aos grupos SHR intacto (SHR int) e castrado (SHR orx) e do respectivo grupo normotenso (W int).

\begin{tabular}{lccc}
\hline Grupos & Wistar Intacto & SHR Intacto & SHR Orquidectomizado \\
Leucócitos & & & \\
\hline Total $^{\mathrm{a}}$ & $11110 \pm 616,4$ & $9850 \pm 817,0$ & $11930 \pm 1239$ \\
Linfócitos $^{\mathrm{a}}$ & $(08)$ & $(06)$ & $(07)$ \\
& $8053 \pm 470,5$ & $7679 \pm 727,5$ & $9295 \pm 921,0$ \\
Neutrófilos $^{\mathrm{a}}$ & $(08)$ & $(06)$ & $(07)$ \\
& $2249 \pm 298,5$ & $1548 \pm 129,6$ & $1736 \pm 342,9$ \\
Monócitos $^{\mathrm{a}}$ & $(08)$ & $(06)$ & $(07)$ \\
& $652,8 \pm 189,6$ & $513,8 \pm 79,9$ & $717,2 \pm 151,8$ \\
Eosinófilos $^{\mathrm{a}}$ & $(08)$ & $(06)$ & $(07)$ \\
& $154,5 \pm 42,4$ & $109,6 \pm 44,6$ & $180,7 \pm 47,9$ \\
& $(08)$ & $(06)$ & $(07)$ \\
\hline
\end{tabular}

${ }^{\mathrm{a}}=$ Resultados apresentados como média \pm EPM.

O número de ratos utilizados em cada grupo encontra-se entre parênteses. 


\subsection{Imunohistoquímica para Determinação da Expressão Protéica de P-selectina e ICAM-1}

Foram encontradas diferenças entre o controle negativo e a expressão constitutiva (basal) tanto da molécula de adesão P-selectina quanto de ICAM-1, comprovando a marcação pelos anticorpos utilizados. Animais do grupo SHR int apresentaram aumento da expressão de P-selectina (Figura 17) e ICAM-1 (Figura 18) em vênulas mesentéricas. A castração reduziu a expressão de P-selectina (Figura 17), contudo não interferiu na expressão de ICAM-1 (Figura 18) quando comparado ao grupo $\mathrm{W}$ int.
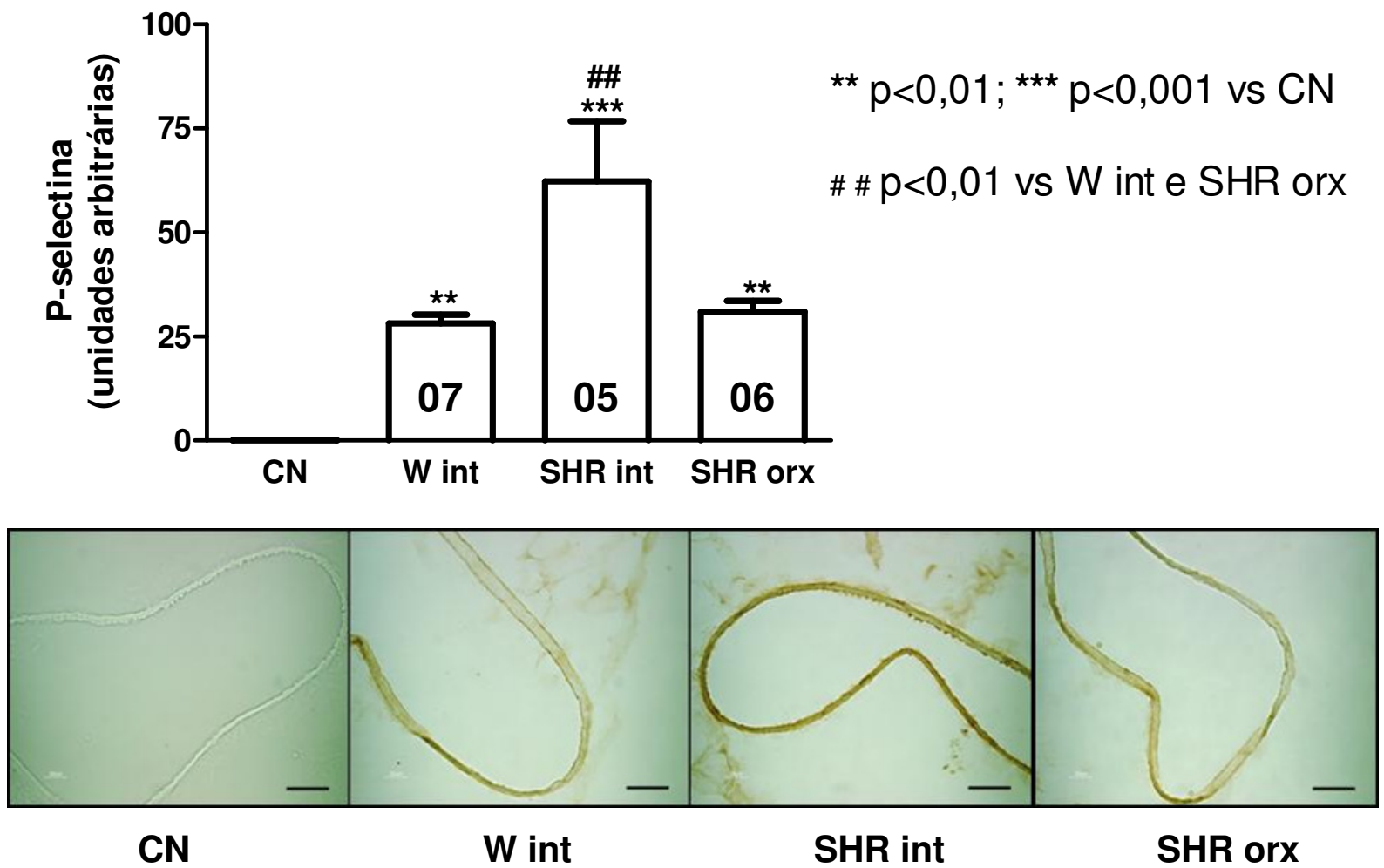

Figura 17 - Expressão protéica de P-selectina em unidades arbitrárias em vênulas mesentéricas não estimuladas de animais pertencentes aos grupos SHR intacto (SHR int) e castrado (SHR orx) e do respectivo grupo normotenso (W int). O controle negativo ( $\mathrm{CN}, \mathrm{n}=5)$ foi submetido a todos os passos inerentes à técnica de imunohistoquímica, exceto a incubação com o anticorpo primário. Cada barra representa a média \pm EPM. $O$ número de ratos utilizados em cada grupo encontra-se no interior das barras. As imagens correspondem a microfotografias representativas da intensidade de marcação de P-selectina em cada grupo. Barra igual a $40 \mu \mathrm{m}$. 

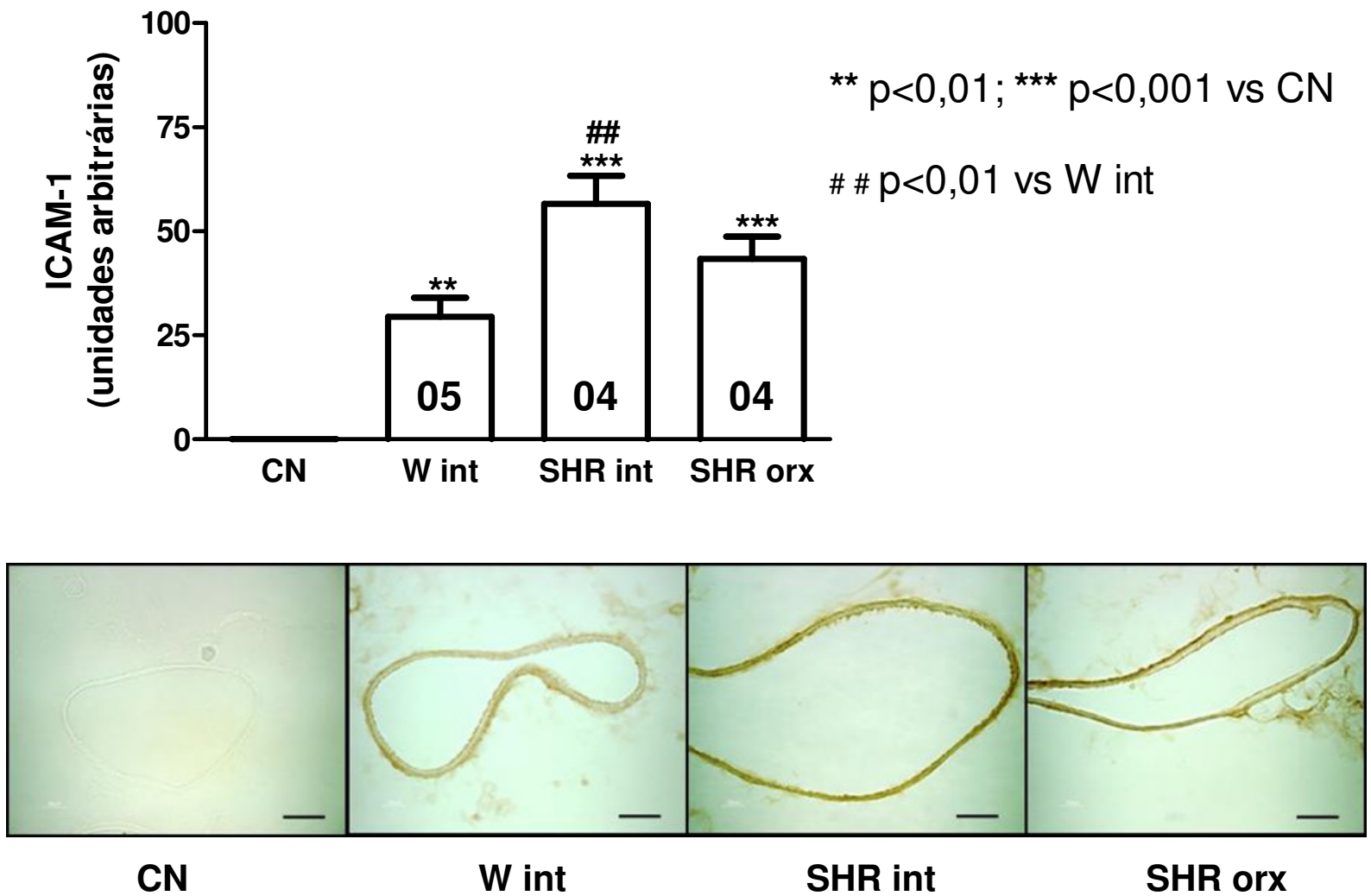

Figura 18 - Expressão protéica de ICAM-1 em unidades arbitrárias em vênulas mesentéricas não estimuladas de animais pertencentes aos grupos SHR intacto (SHR int) e castrado (SHR orx) e do respectivo grupo normotenso (W int). O controle negativo $(\mathrm{CN}, \mathrm{n}=4)$ foi submetido a todos os passos inerentes à técnica de imunohistoquímica, exceto a incubação com o anticorpo primário. Cada barra representa a média \pm EPM. O número de ratos utilizados em cada grupo encontra-se no interior das barras. As imagens correspondem a microfotografias representativas da intensidade de marcação de P-selectina em cada grupo. Barra igual a $40 \mu \mathrm{m}$. 


\subsection{RT-PCR para Determinação da Expressão Gênica de ICAM-1, VCAM-1 e} PECAM-1

A expressão gênica de ICAM-1 (Figura 19) foi semelhante entre os grupos estudados. Por outro lado, animais do grupo SHR int apresentaram aumento da expressão gênica de VCAM-1 (Figura 20) e PECAM-1 (Figura 21), que foi revertido pela castração a níveis observados no grupo $\mathrm{W}$ int.

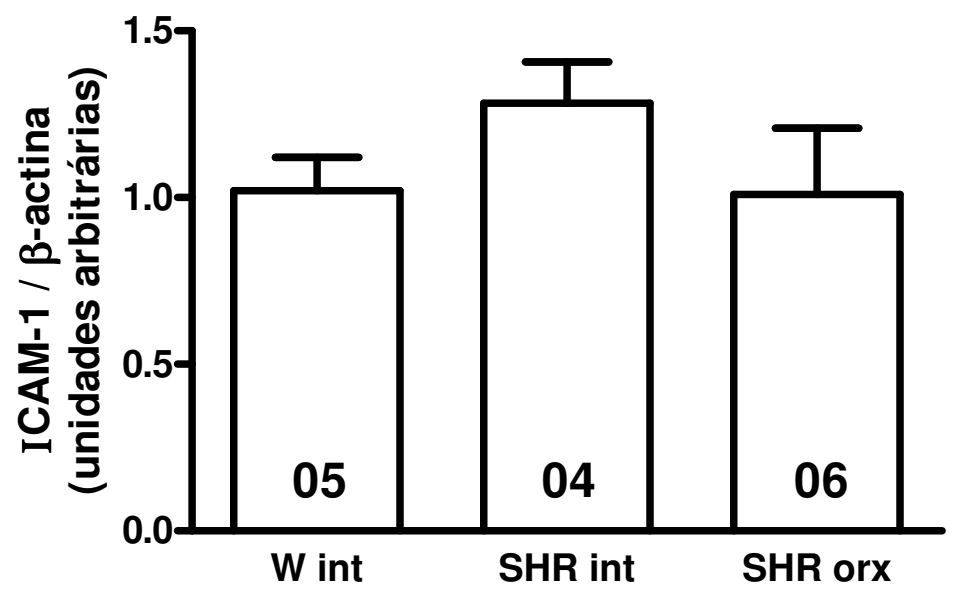

Figura 19 - Expressão gênica de ICAM-1 em unidades arbitrárias em microvasos mesentéricos não estimulados de animais pertencentes aos grupos SHR intacto (SHR int) e castrado (SHR orx) e do respectivo grupo normotenso (W int). O cDNA sintetizado a partir do mRNA da $\beta$-actina foi utilizado para a normalização. Cada barra representa a média \pm EPM. $O$ número de ratos utilizados em cada grupo encontra-se no interior das barras. 


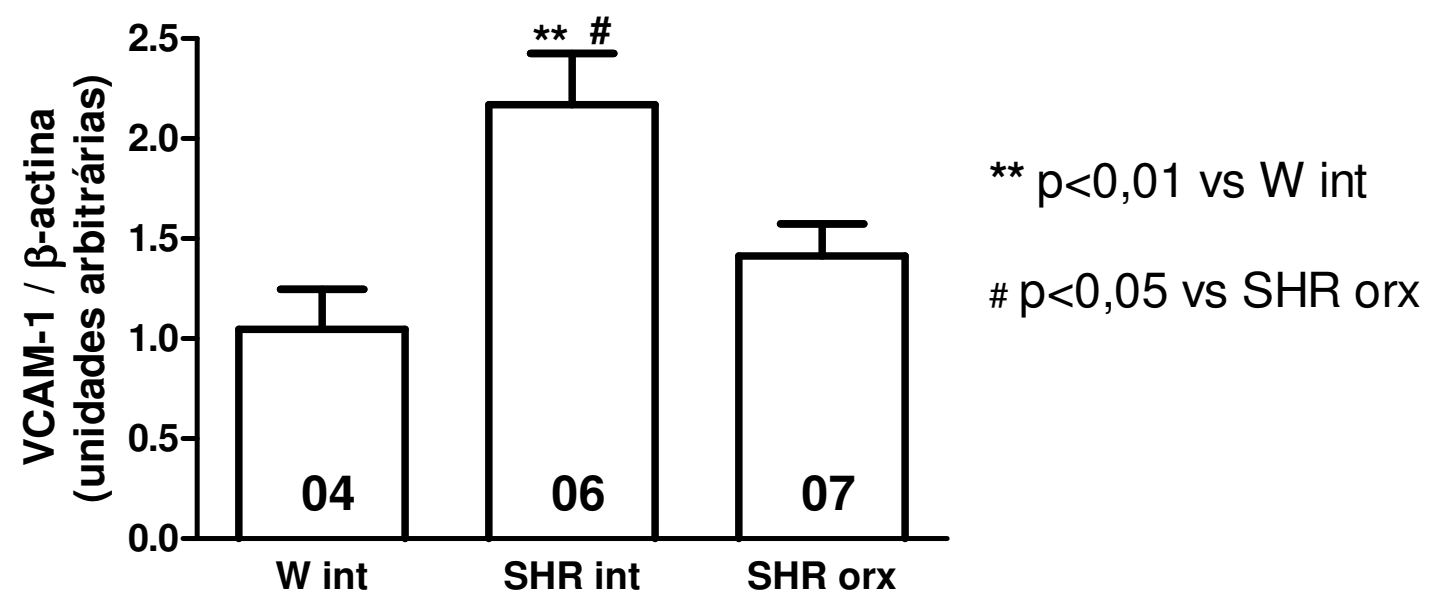

Figura 20 - Expressão gênica de VCAM-1 em unidades arbitrárias em microvasos mesentéricos não estimulados de animais pertencentes aos grupos SHR intacto (SHR int) e castrado (SHR orx) e do respectivo grupo normotenso (W int). O cDNA sintetizado a partir do mRNA da $\beta$-actina foi utilizado para a normalização. Cada barra representa a média \pm EPM. $O$ número de ratos utilizados em cada grupo encontra-se no interior das barras. 


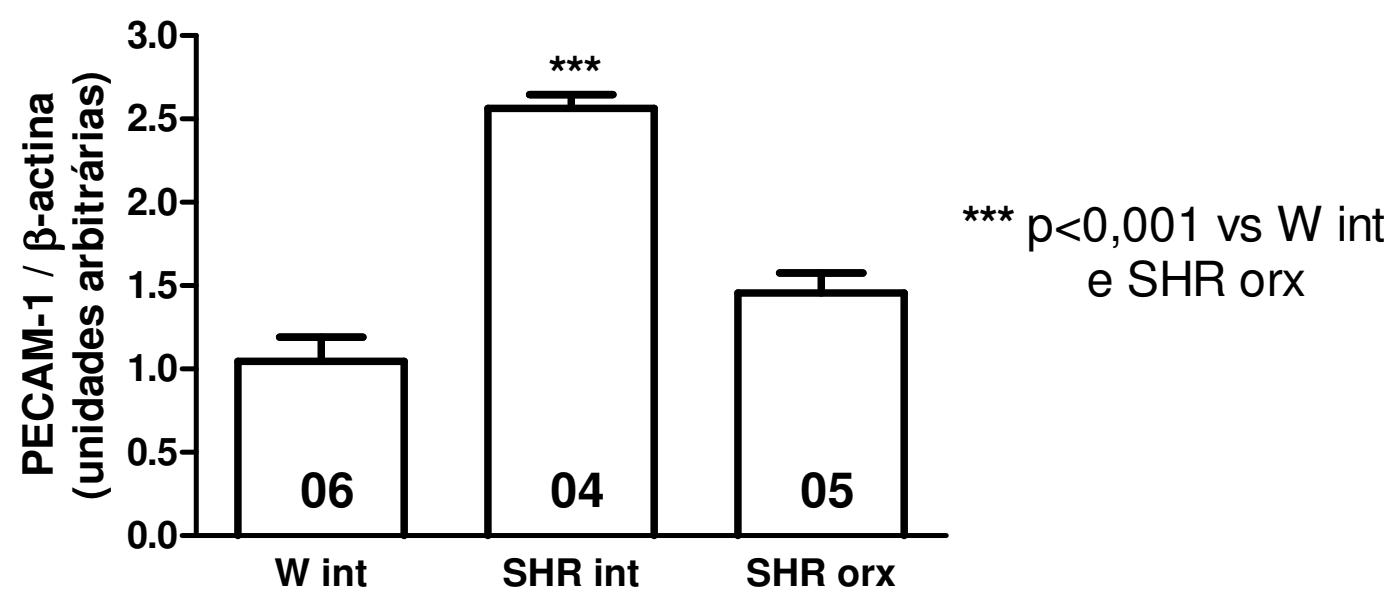

Figura 21 - Expressão gênica de PECAM-1 em unidades arbitrárias em microvasos mesentéricos não estimulados de animais pertencentes aos grupos SHR intacto (SHR int) e castrado (SHR orx) e do respectivo grupo normotenso (W int). O cDNA sintetizado a partir do mRNA da $\beta$-actina foi utilizado para a normalização. Cada barra representa a média \pm EPM. O número de ratos utilizados em cada grupo encontra-se no interior das barras. 


\section{DISCUSSÃO}

No presente trabalho, demonstramos que a hipertensão arterial interfere no comportamento leucocitário e que os andrógenos podem ter participação importante neste processo. O número de leucócitos circulantes e os parâmetros hemodinâmicos como velocidade do fluxo sanguíneo e taxa de atrito venular parecem não estar envolvidos nas alterações da interação leucócito-endotélio em SHRs e no efeito promovido pela castração. Nos ratos hipertensos, o aumento da expressão protéica das moléculas de adesão P-selectina e ICAM-1, bem como da expressão gênica VCAM-1 e PECAM-1 contribuem para o aumento do rolamento e da adesão leucocitária e a castração corrige as alterações do comportamento leucocitário interferindo na expressão dessas moléculas.

A castração de animais SHR em nosso estudo promoveu diminuição da pressão arterial quando comparados com SHRs intactos, o que nos indica que os andrógenos modulam os níveis pressóricos desses animais. Nossos resultados estão de acordo com aqueles encontrados por Masubuchi e colaboradores (1982) e Reckelhoff e colaboradores (1998). Além disso, esses últimos demonstraram que a exacerbação dos níveis pressóricos em SHRs ocorre com 12 semanas, período no qual os níveis séricos de testosterona atingem concentrações máximas. Já está bem estabelecido em nosso laboratório que a hipertensão em animais SHR torna-se estável a partir da $12^{\underline{a}}$ semana, o que justifica a escolha do período de castração dos ratos hipertensos utilizados em nosso estudo. O fato por nós verificado de que os níveis séricos de testosterona encontram-se elevados em SHRs quando comparados aos ratos Wistar fornecem suporte à hipótese aventada anteriormente quanto ao papel desse hormônio contribuindo para a elevação dos níveis pressóricos.

Embora Reckelhoff e colaboradores (1999) tenham demonstrado que a hipertensão em SHRs pode ser mediada por receptor de andrógeno, os mecanismos pelos quais os andrógenos modulam a pressão arterial ainda não estão totalmente esclarecidos. Sugere-se que estes hormônios possam modular o sistema reninaangiotensina e reduzir a pressão de natriurese renal (RECKELHOFF et al., 1998; 
RECKELHOFF et al., 2000). A testosterona pode também estimular várias vias vasoconstritoras de modo direto e indireto. Neste sentido, foi demonstrado que este hormônio pode promover aumento da ação de mediadores vasoconstritores como a norepinefrina, a endotelina-1 e o TXA 2 , além de reduzir a ação de vasodilatadores como a adenosina (KIENITZ e QUINKLER, 2008). Outra hipótese que pode ser proposta baseada em estudos realizados recentemente em nosso laboratório, é que a testosterona, por gerar EROs em células de músculo liso vascular de SHRs (dados não publicados), possa contribuir na modulação da pressão arterial. De fato, Nabha e colaboradores (2005) demonstraram que o tratamento de SHRs com tempol, seqüestrador de EROs, reduziu os níveis pressóricos desses animais. Entretanto, o papel da testosterona mediando este efeito ainda precisa ser elucidado.

Diversos estudos demonstram que os leucócitos, além de apresentar uma função imunológica benéfica, estão envolvidos também na etiologia de DCVs, promovendo lesão tecidual. Sabe-se que os leucócitos circulantes, apesar de seu pequeno número quando comparados aos eritrócitos, têm substancial influência sobre parâmetros hemodinâmicos na microcirculação (SCHMID-SCHÖNBEIN et al., 1991), sendo capazes de induzir a produção de EROs e mediadores da degradação tecidual proteolítica (WEISS, 1989). A hipertensão arterial está associada à disfunção endotelial e dano vascular, promovendo ativação de células endoteliais e recrutamento de células inflamatórias. Isso nos sugere que a lesão em órgãos alvo durante a hipertensão possa estar, ao menos em parte, associada com a atividade de leucócitos na circulação.

Embora esteja bem estabelecido que as interações leucócito-endotélio possam estar envolvidas na disfunção vascular e lesão tecidual em doenças vasculares, os dados referentes ao comportamento leucocitário na hipertensão arterial são escassos e contraditórios. Adicionalmente, as diferenças relacionadas ao sexo na incidência de DCVs têm despertado considerável interesse com relação ao papel potencial dos hormônios sexuais no desenvolvimento das alterações vasculares associadas a essas condições. Assim, considerando que alterações nas células envolvidas na resposta inflamatória podem contribuir para a hipertensão arterial (OFOSU-APPIAH et al., 1997), e que os andrógenos podem ter participação 
importante nesse processo, torna-se relevante o estudo do comportamento de leucócitos na hipertensão e a interferência da castração sobre este parâmetro.

Para investigar esta hipótese, utilizamos em nosso estudo a técnica de microscopia intravital, pois é considerada uma das melhores ferramentas para o entendimento do processo de interação leucócito-endotélio in vivo in situ, de maneira qualitativa e quantitativa (GAVINS e CHATTERJEE, 2004). Esta técnica foi descrita por Zweifach em 1948 e adaptada com algumas modificações em nosso laboratório (FORTES et al., 1991).

Para garantir maior integridade das preparações de leito mesentérico vascular frente à exposição do mesmo após laparotomia, introduzimos modificações incluindo um sistema de superfusão na técnica acima referida. Essencialmente, alguns tecidos acessíveis à microscopia intravital podem ser usados no estudo do processo inflamatório, geralmente aqueles que apresentam membranas finas e transparentes como, por exemplo, o mesentério (LEY e GAEHTGENS, 1991).

Uma das limitações da técnica de microscopia intravital é que a manipulação cirúrgica pode levar ao aumento do número de leucócitos rolando sobre a superfície endotelial. Assim, é razoável assumir que a exteriorização do tecido da cavidade abdominal está associada com o processo da inflamação e, consequentemente, com uma mudança significante do rolamento leucocitário. Fiebig e colaboradores (1991) demonstraram que imediatamente após a exteriorização do mesentério, o fluxo de leucócitos rolando está aumentado, mas com o tempo, este declina para um nível constante. Esses dados explicam o fato de utilizarmos o período de 30 minutos de estabilização antes da avaliação dos parâmetros de nosso estudo.

Vênulas pós-capilares mesentéricas foram escolhidas em nosso estudo para observações sobre a interação leucócito-endotélio, por serem consideradas o melhor local para adesão do leucócito à parede vascular em resposta a um estímulo inflamatório (FORTES et al., 1991).

Os mastócitos, células localizadas estrategicamente próximo aos microvasos, podem liberar moléculas pró-inflamatórias durante a manipulação do tecido e, assim, induzir o recrutamento celular (KUBES e KANWAR, 1994). Para avaliarmos alterações que viriam a prejudicar a análise dos resultados devido à desgranulação dos mastócitos, as preparações foram coradas com azul de toluidina 
ao final dos experimentos (SUZUKI et al., 1991). Dessa maneira, foi possível certificarmos a qualidade da preparação após a exteriorização e realização dos experimentos, descartando aquelas onde ocorria desgranulação excessiva de mastócitos.

O agente inflamatório utilizado em nosso estudo para induzir aderência e migração leucocitária em vênulas pós-capilares mesentéricas foi o leucotrieno $\mathrm{B}_{4}$ $\left(\mathrm{LTB}_{4}\right)$, um produto do metabolismo do ácido araquidônico pela via da lipoxigenase, que é gerado primariamente por polimorfonucleares (FORD-HUTCHINSON, 1980) e fagócitos mononucleares (RANKIN et al., 1990). Estudos demonstraram que o $\mathrm{LTB}_{4}$ é eficaz em promover adesão e migração leucocitária (ARNDT et al., 1993). Além do $\mathrm{LTB}_{4}$, diversos mediadores inflamatórios, incluindo PAF, histamina, citocinas e quimiocinas promovem rolamento, aderência e migração leucocitária quando aplicados diretamente sobre vênulas pós-capilares (PANÉS e GRANGER, 1998). No presente estudo, comprovamos a eficácia do agente inflamatório ( $\left.\mathrm{LTB}_{4}\right)$, demonstrada pela capacidade do mesmo em promover adesão e migração leucocitária em vênulas pós-capilares mesentéricas dos ratos pertencentes a todos os grupos estudados, quando comparados à condição basal.

Este foi o primeiro trabalho a avaliar o papel da castração sobre 0 comportamento leucocitário em vênulas pós-capilares na hipertensão. Durante o desenvolvimento da resposta inflamatória, ocorre o recrutamento leucocitário, que compreende três estágios: rolamento, adesão e migração transendotelial, com a participação de diferentes famílias de moléculas de adesão (KUBES, 2002).

Em nosso estudo, o rolamento leucocitário foi determinado após o período de estabilização, sem a necessidade de estímulo com agente inflamatório para a avaliação deste parâmetro. Observamos que o número de leucócitos rolando sobre a superfície endotelial mesentérica do grupo SHR intacto está aumentado em relação ao grupo Wistar intacto, e que após a castração dos SHRs este parâmetro foi revertido para nível similar àquele do grupo normotenso.

Tem sido amplamente estabelecido que o rolamento de leucócitos ao longo do endotélio constitui um pré-requisito para subseqüente adesão e migração leucocitária (KUBES e KERFOOT, 2001), o que justifica então, nossos resultados demonstrando que a aderência leucocitária induzida por $\mathrm{LTB}_{4}$ em SHR intacto está 
também aumentada em relação ao Wistar intacto. A castração dos SHRs reverteu esse parâmetro ao nível do grupo controle, de modo similar ao observado no rolamento leucocitário. Esses resultados observados na microcirculação in vivo, estão de acordo com outros estudos realizados in vitro, onde se demonstrou aumento de adesão de monócitos e da expressão de CAMs em células endoteliais de SHRs quando comparados ao grupo normotenso (WKY), após estímulo inflamatório (McCARRON et al., 1994a; McCARRON et al., 1994b). Resultado semelhante foi observado em nosso laboratório utilizando outro modelo animal de hipertensão (DOCA-sal) (CALLERA et al., 2004). Trabalhos mostram ainda um aumento na adesão de monócitos isolados em células endoteliais aórticas de SHRs (TSAO et al., 1998).

Estudos clínicos demonstraram, in vitro, que leucócitos de pacientes hipertensos apresentam aderência aumentada (BLANK et al., 1990), e aumento da geração de EROs (KRISTAL et al., 1998), facilitando a interação de leucócitos com o endotélio venular, o que poderia explicar os resultados por nós verificados. De fato, em estudos experimentais, os leucócitos de animais hipertensos se encontram em um estado ativado como reflexo do aumento na produção de superóxido (SCHMIDSCHÖNBEIN et al., 1991).

De modo diferente ao encontrado em nosso estudo, Arndt e colaboradores (1993), demonstraram diminuição no número de leucócitos aderidos em vênulas mesentéricas de SHRs em relação ao WKY. Fatores como: a idade dos animais e diferentes linhagens utilizadas como controle normotenso, o anestésico utilizado, o período de superfusão do agente inflamatório e o diâmetro das vênulas avaliadas, poderiam explicar as diferenças entre os estudos. Além disso, é importante acrescentar que estes autores demonstraram aumento da taxa de atrito venular, fator que pode contribuir para a redução da adesão leucocitária.

Condições como a hipertensão, o diabetes e a hipercolesterolemia são fatores de risco para o desenvolvimento de doença vascular isquêmica. Evidências indicam que estes fatores, isolados ou em combinação, podem aumentar a vulnerabilidade aos efeitos deletérios da isquemia e reperfusão $(I / R)$, dentre os quais se insere a disfunção microvascular. A reperfusão do tecido isquêmico leva a uma resposta caracterizada por lesão que afeta profundamente o segmento venoso da 
microcirculação (KUROSE et al., 1994). As vênulas pós-capilares respondem à $\mathrm{l} / \mathrm{R}$ com aumento nos processos de rolamento, aderência e migração leucocitária, associados à formação de agregados leucócito-plaqueta e diminuição funcional da barreira endotelial com conseqüente aumento do extravasamento de albumina. Esses eventos são geralmente acompanhados por desgranulação de mastócitos e geração de EROs, considerados como principal estímulo para a resposta inflamatória (SCHMID-SCHÖNBEIN et al., 1991).

Hipercolesterolemia e diabetes exacerbam os efeitos promovidos pela $1 / R$, por mecanismos que envolvem o aumento da adesão leucocitária em vênulas pósisquêmicas (PANÉS et al., 1996; KUROSE et al., 1998). Com relação à hipertensão arterial, embora esta condição não altere significativamente o recrutamento leucocitário e plaquetário normalmente observado na $\mathrm{I} / \mathrm{R}$, ela promove aumento acentuado do extravasamento de albumina em vênulas pelas ações deletérias da I/R (KUROSE et al., 1999). Considerando que a magnitude do extravasamento de albumina em vênulas mesentéricas provocada por $\mathrm{l} / \mathrm{R}$ é diretamente proporcional ao número de leucócitos aderidos e migrados (KUROSE et al., 1997), é interessante considerar que, o aumento, observado em nosso estudo, no número de leucócitos rolando e aderidos em vênulas de SHRs intactos pode estar associado a alterações na barreira endotelial em vênulas desses animais, que parecem torná-la mais vulnerável aos danos mediados por leucócitos. Esta vulnerabilidade pode refletir em uma capacidade aumentada dos leucócitos em mediar lesão tecidual em SHRs, visto que neutrófilos de SHRs desgranulam mais rapidamente e produzem maior quantidade de EROs quando estimulados (SCHMID-SCHÖNBEIN et al., 1991; SHEN et al., 1995).

Demonstramos também no presente estudo que a castração dos SHRs, além de reduzir o comportamento de rolamento leucocitário, foi eficaz em reduzir o número de leucócitos aderidos em vênulas pós-capilares mesentéricas, revertendo estes parâmetros aos níveis do grupo controle. Estes dados, em conjunto com os resultados observados em nosso estudo, de que os níveis de testosterona encontram-se elevados em SHRs intactos, leva-nos a sugerir que os andrógenos têm participação importante no desenvolvimento de alterações vasculares, especificamente relacionadas à interação leucócito-endotélio, na hipertensão. 
A migração através da parede venular é a etapa final do processo de passagem de leucócitos em direção ao local da lesão tecidual. Em nosso estudo, a injeção intraperitoneal de solução contendo o estímulo inflamatório ( $\left.\mathrm{LTB}_{4}\right)$ foi eficaz em promover migração transendotelial das células leucocitárias nos grupos estudados. Com o intuito de avaliarmos a interferência da solução nutriente na ausência do agente inflamatório, realizamos o mesmo procedimento apenas com a aplicação da solução nutriente, e verificamos que esta não foi eficiente em promover migração leucocitária.

De modo diferente ao observado no rolamento e na aderência leucocitária, o número de leucócitos migrados na preparação mesentérica dos ratos pertencentes

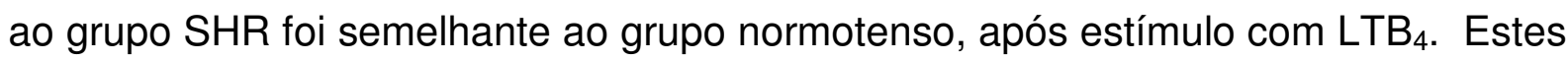
dados estão de acordo com outros estudos demonstrando que a migração leucocitária estimulada com $\mathrm{LTB}_{4}$ em SHRs (ARNDT et al., 1993) e em modelo de hipertensão portal crônica em ratos Sprague-Dawley (PANÉS et al., 1999) não foi diferente quando comparados aos respectivos grupos controles. A castração do grupo SHR não alterou este parâmetro, sugerindo que a falta dos andrógenos não interfere nesta etapa do comportamento leucocitário.

A lesão tecidual durante a hipertensão crônica pode, ao menos em parte, estar associada com a atividade dos leucócitos na circulação. Os leucócitos podem ser encontrados de modo essencialmente inativo ou em um estado no qual diversas formas de ativação são manifestadas, incluindo formação de EROs, expressão de CAMs, liberação de citocinas e desgranulação. Embora cada um destes sinais de ativação faça parte da função fisiológica, ativação anormal das células circulatórias pode ocorrer em algumas DCVs (SCHMID-SCHÖNBEIN et al., 1997).

Considerando que o número de leucócitos circulantes constitui um fator importante que influencia o rolamento e a adesão, visto que o recrutamento leucocitário depende da disponibilidade de leucócitos na circulação (LEY et al., 1991), investigamos a influência deste parâmetro em nosso estudo, realizando a contagem de leucócitos total na circulação periférica (sangue caudal). O fato por nós observado, de que o número de células totais e diferenciais não diferiu entre os grupos estudados, levou-nos a sugerir que este parâmetro não está envolvido nas alterações do rolamento e da aderência leucocitária. De modo diferente ao 
observado em nosso estudo, Schmid-Schönbein e colaboradores (1991) demonstraram que SHRs apresentam quantidade elevada de leucócitos em relação ao grupo normotenso (WKY) e que estas células encontram-se mais ativadas no grupo hipertenso, constituindo um risco aumentado à lesão tecidual em SHRs. A diferença observada entre os estudos pode ser justificada pelo fato de que a contagem de células brancas pode ser influenciada dependendo do território vascular onde foi realizado a coleta (VAN HERCK et al., 2001), e estes autores utilizaram amostras de sangue central, enquanto que em nosso estudo, utilizamos sangue periférico.

Sabe-se que durante o processo inflamatório, os leucócitos são rapidamente transportados através do sistema circulatório ao local de lesão tecidual, onde aderem ao endotélio e migram para o espaço intersticial (GRANT et al., 1973). Estes eventos dependem da interação de parâmetros hemodinâmicos (fluxo e resistência) que afetam o transporte de leucócitos e o balanço das forças que os removem do local da lesão (SCHMID-SCHÖNBEIN et al., 1975). Assim, diferenças de natureza morfológica ou funcional existem entre as células endoteliais dos vasos da microcirculação que, associados às diferenças hemodinâmicas, determinam o grau de interação leucócito-endotélio na microcirculação (LEY e GAEHTGENS, 1991).

Portanto, para investigarmos a possível interferência dos parâmetros hemodinâmicos sobre as alterações observadas no comportamento leucocitário, avaliamos a velocidade do fluxo sanguíneo e o diâmetro venular. Calculamos também a taxa de atrito sobre a parede vascular, visto que, conforme mencionado, este parâmetro pode também influenciar a aderência leucocitária. De acordo com os resultados obtidos em nosso estudo, nenhuma diferença foi observada na velocidade do fluxo sanguíneo, bem como no diâmetro das vênulas pós-capilares mesentéricas de ratos pertencentes aos grupos estudados. O cálculo da taxa de atrito também não apresentou diferença estatística entre os grupos experimentais por nós estudados.

Com base nestes resultados podemos sugerir que as alterações no comportamento leucocitário promovidas pela hipertensão, bem como pela castração, não podem ser atribuídas a alterações nesses parâmetros hemodinâmicos e que a hipertensão e a castração interferem de fato na interação leucócito-endotélio. 
A expressão de moléculas de adesão sobre a superfície dos leucócitos e células endoteliais é reconhecida como fator determinante do nível de interação leucócito-endotélio mantida pela microvasculatura (KOMATSU et al., 1997). Neste trabalho investigamos a expressão gênica das CAMs P-selectina, ICAM-1, VCAM-1 e PECAM-1 utilizando a técnica de PCR em tempo real, e a expressão protéica de P-selectina e ICAM-1 por imunohistoquímica indireta. Essas moléculas foram escolhidas pelo fato de se expressarem no endotélio e pela sua importância no comportamento leucocitário, podendo assim estar envolvidas nos efeitos promovidos pela hipertensão e pela ausência de andrógenos.

Em nosso estudo, verificamos que SHRs apresentam aumento da expressão protéica de P-selectina e ICAM-1 nas vênulas mesentéricas, sem alteração na expressão gênica dessa última. Considerando que as selectinas e os membros da superfamília das imunoglobulinas, como a ICAM-1, representam importante papel no processo de rolamento e adesão leucocitária sobre a superfície endotelial, respectivamente, o aumento da expressão protéica dessas moléculas durante o processo inflamatório poderia explicar, ao menos parcialmente, as alterações do comportamento leucocitário observadas nos SHRs. Desse modo, nossos dados indicam que mecanismos de controle pós-transcricionais da expressão dessas moléculas possam estar positivamente sendo regulados nos SHRs.

Similarmente ao observado em nosso estudo, Komatsu e colaboradores (1997) demonstraram que em condições basais, a expressão de ICAM-1 sobre a superfície das células endoteliais mesentéricas e estomacais está aumentada em animais SHR quando comparados ao grupo controle. Por outro lado, estudo realizado em cultura de células endoteliais de microvasos cerebrais de SHR demonstrou que a expressão constitutiva (basal) de ICAM-1 foi similar àquela encontrada no WKY, entretanto, após o estímulo com diferentes citocinas (como, por exemplo, TNF-alfa) e LPS (lipopolissacarídeo), a expressão desta molécula aumentou de maneira significativa (McCARRON et al., 1994a). Esse dado pode justificar o resultado obtido em nosso estudo com relação à expressão gênica da ICAM-1. A expressão dessa molécula de adesão foi determinada em condições basais, enquanto que a aderência leucocitária foi investigada frente ao estímulo com $\mathrm{LTB}_{4}$. Portanto torna-se necessário a realização de estudos adicionais 
avaliando a expressão gênica, e até mesmo protéica, da ICAM-1 após estímulo inflamatório.

Verificamos também em nosso estudo que a redução do rolamento leucocitário promovida pela castração está relacionada com diminuição da expressão protéica de P-selectina. Por outro lado, a reversão da aderência leucocitária nos SHRs castrados não foi acompanhada por redução da expressão da molécula de aderência ICAM-1, sugerindo que a ausência do hormônio não interfere na expressão dessa molécula, o que está de acordo com o trabalho de McCrohon e colaboradores (1999), onde a exposição in vitro a andrógeno não alterou a expressão de ICAM-1.

Devemos considerar ainda, que a adesão leucocitária envolve a participação de outras moléculas de adesão de grande importância, como por exemplo, a VCAM1. Estudos têm demonstrado aumento da expressão dessa molécula em placas ateroscleróticas de modelos animais de hipercolesterolemia induzida por dieta (LI et al.,1993) e em lesões ateroscleróticas de humanos (O'BRIEN et al., 1996). Ao contrário de outras CAMs, a VCAM-1 isoladamente é capaz de mediar a adesão leucocitária via interação com integrina (BERLIN et al., 1995), enquanto que a ICAM1 medeia somente parte do complexo processo de adesão (SPRINGER, 1994).

De fato, em nosso trabalho, demonstramos que a VCAM-1 também pode ter participação importante no aumento da adesão leucocitária observada em SHRs, uma vez que a expressão gênica desta molécula encontra-se aumentada nesses ratos. Resultado semelhante foi observado em nosso laboratório utilizando outro modelo animal de hipertensão (DOCA-sal), onde o aumento da aderência leucocitária foi acompanhado por aumento da expressão de VCAM-1 em relação aos respectivos controles (CALLERA et al., 2004).

Estudos investigando a participação dos andrógenos na expressão de algumas CAMs reforçam os resultados encontrados em nosso trabalho, pois demonstraram que a testosterona aumenta a expressão de VCAM-1 em cultura de células endoteliais via receptor de andrógeno (ZHANG et al., 2002) e ativação de NF-kappaB (DEATH et al., 2004), e em nosso estudo demonstramos que a castração reduz a expressão dessa CAM ao nível do grupo controle. 
PECAM-1 também é um membro da superfamília das imunoglobulinas expressa nas junções entre as células endoteliais, nos leucócitos e nas plaquetas, exercendo papel importante na migração de neutrófilos e monócitos pelas células endoteliais (SCALIA e LEFER, 1998; DANGERFIELD et al., 2002). Além disso, essa molécula parece regular a adesão de neutrófilos ao endotélio, por sua capacidade da ativar $\beta 1$ e $\beta 2$ integrinas (TANAKA et al., 1992). Embora em nosso estudo a expressão dessa molécula não tenha sido avaliada nos leucócitos, podemos inferir que ela pode ter participação na alteração observada na aderência leucocitária em ratos hipertensos e no efeito promovido pela castração, uma vez que SHRs apresentaram aumento na expressão gênica basal de PECAM-1 quando comparados com ratos normotensos, a qual foi revertida nos ratos castrados.

O fato da PECAM-1 ter participação importante na migração leucocitária, juntamente com a expressão gênica alterada desta molécula observada em nosso estudo, leva-nos a sugerir que podem existir alterações na migração leucocitária, que não foram detectadas em virtude do estímulo utilizado. De fato, demonstrou-se que a transmigração induzida pelo $\mathrm{LTB}_{4}$ não depende da presença de PECAM-1, e que essa molécula é regulada por estímulos específicos, como IL-1 $\beta$ (O’BRIEN et al., 2003). Portanto, torna-se relevante a realização de estudos posteriores avaliando este parâmetro frente a outros estímulos quimiotáxicos.

Em resumo, os resultados apresentados em nosso estudo fornecem contribuição importante para o entendimento do papel da hipertensão e dos hormônios sexuais masculinos na resposta inflamatória, influenciando etapas envolvidas no comportamento leucocitário ao alterar a expressão de algumas moléculas de adesão envolvidas no processo. 


\section{CONCLUSÕES}

Com base nos resultados obtidos em nosso estudo, podemos concluir que:

$\checkmark \quad$ Existe aumento no rolamento e adesão de leucócitos na superfície da célula endotelial de vênulas pós-capilares, do leito mesentérico de ratos geneticamente hipertensos (SHR). Esses parâmetros foram corrigidos pela castração cirúrgica desses animais, tornando-os semelhantes àqueles dos ratos normotensos Wistar;

$\checkmark$ Essas alterações no comportamento leucocitário provavelmente se devem ao aumento da expressão protéica das moléculas de adesão Pselectina e ICAM-1, bem como expressão gênica de VCAM-1 e PECAM-1, sendo corrigidas pela castração sugerindo a participação de hormônios gonadais na modulação da função endotelial. 


\section{REFERÊNCIAS BIBLIOGRÁFICAS*}

2003 WORLD HEALTH ORGANIZATION. International Society of Hypertension (ISH) statement on management of hypertension: Guidelines Subcommittee. $\mathbf{J}$. Hypertens., v. 21, n. 11, p. 1983-1992, 2003.

AN, N. M.; KIM, D. D.; SHIN, Y. H.; LEE, C. H. Development of a novel soft hydrogel for the transdermal delivery of testosterone. Drug. Dev. Ind. Pharm., v. 29, n. 1, p. 99-105, 2003.

ARNDT, H.; SMITH, C. W.; GRANGER, D. N. Leukocyte-endothelial cell adhesion in spontaneously hypertensive and normotensive rats. Hypertension, v. 21, p. 667673, 1993.

ASHTON, N.; BALMENT, R. J. Sexual dimorphism in renal function and hormonal status of New Zealand genetically hypertensive rats. Acta Endocrinol., Copenhagen, v. 124, p. 91-97, 1991.

BASARIA, S.; DOBS, A. Andropause: to treat or not to treat? J. Endocrinol. Invest., v. 26, p. $693-697,2003$.

BAZZONI, G.; DEJANA, E. Endothelial Cell-to-Cell Junctions: Molecular Organization and Role in Vascular Homeostasis. Physiol. Rev., v. 84, p. 869-901, 2004.

BÉCHARD, D.; SCHERPEREEL, A.; HAMMAD, H.; GENTINA, T.; TSICOPOULOS, A.; AUMERCIER, M.; PESTEL, J.; DESSAINT, J. P.; TONNEL, A. B.; LASSALLE, P. Human endothelial-cell specific molecule-1 binds directly to the integrin CD11a/CD18 (LFA-1) and blocks binding to intercellular adhesion molecule-1. J. Immunol., v. 167, p. 3099-3106, 2001.

BERLIN, C.; BARGATZE, R. F.; CAMPBELL, J. J.; VON ANDRIAN, U. H.; SZABO, M. C.; HASSLEN, S. R.; NELSON, R. D.; BERG, E. L.; ERLANDSEN, S. L.; BUTCHER, E. C. Alpha 4 integrins mediate lymphocyte attachment and rolling under physiologic flow. Cell, v. 80, n. 3, p. 413-422, 1995.

BEVILACQUA, M. P.; POBER, J. S.; MENDRICK, D. L.; COTRAN, R. S.; GIMBRONE, M. A. Jr. Identification of an inducible endothelial-leukocyte adhesion molecule. Proc. Natl. Acad. Sci. USA, v. 84, p. 9238-9242, 1987.

\footnotetext{
*De acordo com:

ASSOCIAÇÃO BRASILEIRA DE NORMAS TÉCNICAS (ABNT). NBR 6023: informação e documentação: referências: elaboração. Rio de Janeiro, 2002.
} 
BIJL, M. Endothelial activation, endothelial dysfunction and premature atherosclerosis in systemic autoimmune diseases. Neth. J. Med., v. 61, n. 9, p. 273277, 2003.

BLANK, I.; BAUDISCH, W.; BURMEISTER, J.; FRANZ, U. Adhesion, migration and phagocytic behavior of blood granulocytic neutrophils from the rat and humans in essential hypertension. Biomed. Biochem. Acta, v. 49, p. 235-241, 1990.

BORDERS, J. L.; GRANGER, H. J. An optical doppler intravital velocimeter. Microvasc. Res., v. 27, n. 1, p. 117-127, 1984.

BRAIDE, M.; AMUNDSON, B.; CHIEN, S.; BAGGE, U. Quantitative studies on the influence of leukocyte on the vascular resistence in a skeletal muscle preparation. Microsvasc. Res., v. 27, p. 331-352, 1984.

BRISKIN, M. J.; McEVOY, L. M.; BUTCHER, E. C. MAdCAM-1 has homology to immunoglobulin and mucin-like adhesion receptors and to $\lg A 1$. Nature, v. 363, n. 6428, p. 461-464, 1993.

BROWN, R. C.; DAVIS, T. P. Calcium modulation of adherens and tight junction function: a potential mechanism for blood-brain barrier disruption after stroke. Stroke, v. 33, n. 6, p. 1706-1711, 2002.

CALLERA, G. E.; MONTEZANO, A. C.; TOUYZ, R. M.; ZORN, T. M. T.; CARVALHO, M. H. C.; FORTES, Z. B.; NIGRO, D.; SCHIFFRIN, E. L.; TOSTES, R. C. ETA receptor mediates altered leukocyte-endothelial cell interaction and adhesion molecules expression in DOCA-salt rats. Hypertension, v. 43, p. 872-879, 2004.

CARVALHO, M. H. C.; SCIVOLETTO, R.; NIGRO, D.; FORTES, Z. B. Funções fisiológicas do endotélio vascular. Rev. Soc. Cardiol. Est. São Paulo, v. 6, p. 121 128, 1996.

CHEN, Y. F.; MENG, Q. M. Sexual dimorphism of blood pressure in spontaneously hypertensive rats is androgen dependent. Life Sci., v. 48, p. 85-96, 1991.

CHOU, T. M.; SUDHIR, K.; HUTCHISON, S. J.; KO, E.; AMIDON, T. M.; COLLINS, P.; CHATTERJEE, K. Testosterone induces dilation of canine coronary conductance and resistance arteries in vivo. Circulation, v. 94, n. 10, p. 2614-2619, 1996.

COllaRES-BUZATO, C. B.; LEITE, A. R.; BOSCHERO, A. C. Modulation of gap and adherens junctional proteins in cultured neonatal pancreatic islets. Pancreas, $v$. 23, n. 2, p. 177-185, 2001. 
COOPER, D.; STOKES, K. Y.; TAILOR, A.; GRANGER, D. N. Oxidative stress promotes blood cell-endothelial cell interactions in the microcirculation. Cardiovasc. Toxicol., v. 2, n. 3, p. 165-180, 2002.

CORRALES, J. J.; BURGO, R. M.; GARCA-BERROCAL, B.; ALMEIDA, M.; ALBERCA, I.; GONZALEZ-BUITRAGO, J. M.; ORFAO, A.; MIRALLES, J. M. Partial androgen deficiency in aging type 2 diabetic men and its relationship to glycemic control. Metabolism, v. 53, p. 666-672, 2004.

COSTARELLA, C. E.; STALLONE, J. N.; RUTECKI, G. W.; WHITTIER, F.C. Testosterone causes direct relaxation of rat thoracic aorta. J. Pharmacol. Exp. Ther., v. 277, n. 1, p. 34-39, 1996.

CREWS, J. K.; KHALIL, R. A. Antagonistis effects of 17 beta-estradiol, progesterone, and testosterone on $\mathrm{Ca}^{2+}$ entry mechanisms of coronary vasoconstriction. Arterioscler. Thromb. Vasc. Biol., v. 19, n. 4, p. 1034-1040, 1999a.

CREWS, J. K.; KHALIL, R. A. Gender-specific inhibition of Ca2+ entry mechanisms of arterial vasoconstriction by sex hormones. Clin. Exp. Pharmacol. Physiol., v. 26, p. 707-715, 1999b.

CROFTON, J. T.; SHARE, L. Gonadal hormones modulate deoxycorticosterone-salt hypertension in male and female rats. Hypertension, v. 29, p. 494-499, 1997.

CURRY, F. E. Modulation of venular microvessel permeability by calcium. FASEB J., v. 6, p. 2456-2466, 1992.

DANGERFIELD, J.; LARBI, K.Y.; HUANG, M.T.; DEWAR, A.; NOURSHARGH, S. PECAM-1 (CD31) homophilic interaction up-regulates $\alpha 6 \beta 1$ on transmigrated neutrophils in vivo and plays a functional role in ability of a6 integrins to mediate leukocyte migration through the perivascular basement membrane. J. Exp. Med., v. 196, p. 1201-1211, 2002.

DANTAS, A. P.; FRANCO, M. C.; SILVA-ANTONIALLI, M. M.; TOSTES, R. C.; FORTES, Z. B.; NIGRO, D.; CARVALHO, M. H. C. Gender differences in superoxide generation in microvessels of hypertensive rats: role of $\mathrm{NAD}(\mathrm{P}) \mathrm{H}$-oxidase. Cardiovasc. Res., v. 61, n. 1, p. 22-29, 2004.

DEATH, A. K.; McGRATH, K. C. Y.; SADER, M. A.; NAKHLA, S.; JESSUP, W.; HANDELSMAN, D. J.; CELERMAJER, D. S. Dihydrotestosterone promotes vascular cell adhesion molecule-1 expression in male human endothelial cells via a nuclear factor-kB-dependent pathway. Endocrinology, v. 145, p. 1889-1897, 2004. 
DZAU, V. J.; GONZELES, D.; KAEMPFER, C.; DUBLIN, C.; WINTROUB, B. U. Human neutrophils release serine proteases capable of activating prorenin. Circ. Res., v. 36, p. 595-601, 1987.

ERNTS, E.; HAMMERSCHMIDT, E.; BAGGE, U.; MATRAI, A.; DORMANDY, J. A. Leukocytes and the risk of ischemic disease. JAMA, v. 257, p. 2318-2324, 1987.

FÉlÉTOU, M.; VANHOUTTE, P. M. The alternative: EDHF. J. Mol. Cell. Cardiol., v. 31, n. 1, p. 15-22, 1999.

FERRO, C. J.; WEBB, D. J. The clinical potencial of endothelin receptor antagonist in cardiovascular medicine. Drugs, v. 51, p. 12-27, 1996.

FIEBIG, E.; LEY, K.; ARFORS, K. E. Rapid leukocyte accumulation by "spontaneous" rolling and adhesion in the exteriorized rabbit mesentery. Int. J. Microcirc. Clin. Exp., v. 10, p. 127-144, 1991.

FLOREY, H. W., Inflammation. In: General Pharmacology. 4. ed. Philadelphia: Saunders, 1970. p.22-123.

FORD-HUTCHINSON AW, BRAY MA, DOIG MV, SHIPLEY ME, SMITH MJ. Leukotriene $B$, a potent chemokinetic and aggregating substance released from polymorphonuclear leukocytes. Nature, v. 286, p. 264-265, 1980.

FORTES, Z. B.; FARSKY, S. P.; OLIVEIRA, M. A.; GARCIA-LEME, J. Direct vital microscopic study of defective leukocyte-endothelial interaction in diabetes mellitus. Diabetes, v. 40, n. 10, p. 1267-1273, 1991.

FURCHGOTT, R. F.; VANHOUTTE, P.M. Endothelium-derived relaxing and contracting factors. FASEB J., v. 3, n. 9, p. 2007-2018, 1989.

FURUSE, M.; HIRASE, T.; ITOH, M.; NAGAFUCHI, A.; YONEMURA, S.; TSUKITA, S.; TSUKITA, S. Occludin: a novel integral membrane protein localizing at tight junctions. J. Cell. Biol., v. 123, n. 6, p. 1777-1788, 1993.

FURUSE, M.; SASAKI, H.; TSUKITA, S. Manner of interaction of heterogeneous claudin species within and between tight junction strands. J. Cell. Biol., v. 147, n. 4, p. 891-903, 1999.

GAVINS, F. N. E.; CHATTERJEE, B. E. Intravital microscopy for the study of mouse microcirculation in anti-inflammatory drug research: focus on the mesentery and cremaster preparation. J. Pharmacol. Toxocol. Methods, v. 49, n. 1, p. 1-14, 2004. 
GEIGER, B.; AYALON, O. Cadherins. Annu. Rev. Cell. Biol., v. 8, p. 307-332, 1992.

GRANGER, D. N.; KVIETYS, P. R.; PERRY, M. A. Leukocyte-endothelial cell adhesion induced by ischemia and reperfusion. Can. J. Physiol. Pharmacol., v. 71, n. 1 , p. $67-75,1993$.

GRANGER, D. N.; VOWINKEL, T.; PETNEHAZY, T. Modulation of the inflammatory response in cardiovascular disease. Hypertension, v. 43, n. 5, p. 924-931, 2004.

GRANT L. The sticking and emigration of white blood cells in inflammation. In: ZWEIFACH, B. W.; GRANT, L.; McCLUSKEY, L. (Ed.). The Inflammatory Process. Orlando, Fla: Academic Press, 1973. v. 2, p. 205-249.

HARMAN, S. M.; METTER, E. J.; TOBIN, J. D.; PEARSON, J.; BLACKMAN, M. R. Longitudinal effects of aging on serum total and free testosterone levels in healthy men. Baltimore Longitudinal Study of Aging. J. Clin. Endocrinol. Metab., v. 86, n. 2, p. 724-731, 2001.

HEINLEIN, C. A.; CHANG, C. The roles of androgen receptors and androgen-binding proteins in nongenomic androgen actions. Mol. Endocrinol., v. 16, p. 2181-2187, 2002.

HENRICKS, P. A.; NIJKAMP, F. P. Pharmacological modulation of cell adhesion molecules. Eur. J. Pharmacol., v. 344, p. 1-13, 1998.

HONDA, H.; UNEMOTO, T.; KOGO, H. Different mechanisms for testosteroneinduced relaxation of aorta between normotensive and spontaneously hypertensive rats. Hypertension, v. 34, p. 1232-1236, 1999.

HOUSE, S. D.; LIPOWSKY, H. H. Leukocyte-endothelium adhesion: Microhemodynamics in mesentery of the cat. Microvas. Res., v. 34, p. 363-379, 1987.

HSU-LIN, S.; BERMAN, C. L.; FURIE, B. C.; AUGUST, D.; FURIE, B. A platelet membrane protein expressed during platelet activation and secretion. Studies using a monoclonal antibody specific for thrombin-activated platelets. J. Biol. Chem., v. 259, p. 9121-9126, 1984.

HUBBARD, A.; ROTHLEIN, R. Intercellular adhesion molecule-1 (ICAM-1) expression and cell signaling cascades. Free Radic. Biol. Med., v. 28, p. 1379-1386, 2000. 
HUTCHISON, S. J.; SUDHIR, K.; CHOU, T. M.; SIEVERS, R. E.; ZHU, B. Q.; SUN, Y. P.; DEEDWANIA, P. C.; GLANTZ, S. A.; PARMLEY, W. W.; CHATTERJEE, K. Testosterone worsens endothelial dysfunction associated with hypercholesterolemia and environmental tobacco smoke exposure in male rabbit aorta. J. Am. Coll. Cardiol., v. 29, p. 800-807, 1997.

ISIDORI, A. M.; GRECO, E. A.; AVERSA, A. Androgen deficiency and hormonereplacement therapy. BJU Int., v. 96, n. 2, p. 212-216, 2005.

JOHNSTON, B.; ISSEKUTZ, T. B.; KUBES, P. The a4-integrin supports leukocyte rolling and adhesion in chronically inflamed postcapillary venules in vivo. J. Exp. Med., v. 181, p. 1995-2006, 1996.

KÄHÖNEN, M.; TOLVANEN, J. P.; SALLINEN, K.; WU, X.; PÖRSTI, I. Influence of gender on control of arterial tone in experimental hypertension. Am. J. Physiol., v. 275, p. 15-22, 1998.

KEARNEY, P. M.; WHELTON, M.; REYNOLDS, K.; MUNTNER, P.; WHELTON, P.K.; HE, J. Global burden of hypertension: analysis of worldwide data. Lancet, v. 365, p. 217-223, 2005.

KELLY, M.; HWANG, J. M.; KUBES, P. Modulating leukocyte recruitment in inflammation. J. Allergy Clin. Immunol., v. 120, n. 1, p. 3-10, 2007.

KHALIL, R. A. Sex hormones as potential modulators of vascular function in hypertension. Hypertension, v. 46, n. 2, p. 249-254, 2005.

KIENITZ, T.; QUINKLER, M. Testosterone and Blood Pressure Regulation. Kidney Blood Press. Res., v. 31, p. 71-79, 2008.

KNOT, H. J.; LOUNSBURY, K. M.; BRAYDEN, J. E.; NELSON, M.T. Gender differences in coronary artery diameter reflect changes in both endothelial $\mathrm{Ca} 2+$ and ecNOS activity. Am. J. Physiol., v. 276, p. 961-969, 1999.

KOMATSU, S.; PANÉS, J.; RUSSELL, J. M.; ANDERSON, D. C.; MUZYKANTOV, V. R.; MIYASAKA, M.; GRANGER, D. N. Effects of chronic arterial hypertension on constitutive and induced intercellular adhesion molecule-1 expression in vivo. Hypertension, v. 29, n. 2, p. 683-689, 1997.

KRIEGLSTEIN, C. F.; GRANGER, D. N. Adhesion molecules and their role in vascular disease. Am. J. Hypertens., v. 14, n. 6, p. 44-54, 2001. 
KRISTAL, B.; SHURTZ-SWIRSKI, R.; CHEZAR, J.; MANASTER, J.; LEVY, R.; SHAPIRO, G.; WEISSMAN, I.; SHASHA S. M.; SELA, S. Participation of peripheral polymorphonuclear leukocytes in the oxidative stress and inflammation in patients with essential hypertension. Am. J. Hypertens., v. 11, p. 921-928, 1998.

KUBES, P.; KANWAR, S. Histamine induces leukocyte rolling in post-capillary venules. A P-selectin-mediated event. J. Immunol., v. 152, n. 7, p. 3570-3577, 1994.

KUBES, P.; KERFOOT, S. M. Leukocyte recruitment in the microcirculation: the rolling paradigm revisited. News Physiol. Sci., v. 16, p. 76-80, 2001.

KUBES, P. Introduction: The complexities of leukocyte recruitment. Semin. Immunol., v. 14, p. 65-72, 2002.

KUROSE, I.; ANDERSON, D. C.; MIYASAKA, M.; TAMATANI, T.; PAULSON, J. C.; TODD, R. F.; RUSCHE, J. R.; GRANGER, D. N. Molecular determinants of reperfusion-induced leukocyte adhesion and vascular protein leakage. Circ. Res., v. 74, p. 336-343, 1994.

KUROSE, I.; ARGENBRIGHT, L. W.; ANDERSON, D. C.; TOLLEY, J.; MIYASAKA, M.; HARRIS, N.; GRANGER, D. N. Reperfusion-induced leukocyte adhesion and vascular protein leakage in normal and hypercholesterolemic rats. Am. J. Physiol., v. 273, p. 854-860, 1997.

KUROSE, I.; WOLF, R. E.; GRISHAM, M. B.; GRANGER, D. N. Hypercholesterolemia enhances oxidant production in mesenteric venules exposed to Ischemia/Reperfusion. Arterioscler. Thromb. Vasc. Biol., v. 18, n. 10, p. 15831588, 1998.

KUROSE, I.; WOLF, R. E.; CERWINKA, W.; GRANGER, D. N. Microvascular responses to ischemia/reperfusion in normotensive and hypertensive rats. Hypertension, v. 34, p. 212-216, 1999.

LAMBERTS, S. W. J.; van den BELD, A. W.; van der LELY, A. J. The endocrinology of aging. Science, v. 278, p. 419-424, 1997.

LAUGHLIN, G. A.; BARRETT-CONNOR, E.; KRITZ-SILVERSTEIN, D.; VON MUHLEN, D. Hysterectomy, oophorectomy, and endogenous sex hormone levels in older women: the Rancho Bernardo Study. J. Endocrinol. Metab., v. 85, p. 645651, 2000. 
LEY, K.; GAEHTGENS, P. Endothelial, not hemodynamic, differences are responsible for preferential leukocyte rolling in rat mesenteric venules. Circ. Res., v. 69, n. 4, p. 1034-1041, 1991.

LI, H.; CYBULSKY, M. I.; GIMBRONE, M. A. JR.; LIBBY, P. Inducible expression of vascular cell adhesion molecule-1 by vascular smooth muscle cells in vitro and within rabbit atheroma. Am. J. Pathol., v. 143, n. 6, p. 1551-1559, 1993.

LITTLETON-KEARNEY, M.; HURN, P. D. Testosterone as a modulator of vascular behavior. Biol. Res. Nurs., v. 5, n. 4, p. 276-285, 2004.

MARTİN-PADURA, I.; LOSTAGLIO, S.; SCHNEEMANN, M.; WILLIAMS, L.; ROMANO, M.; FRUSCELLA, P.; PANZERI, C.; STOPPACCIARO, A.; RUCO, L.; VILLA, A.; SIMMONS, D.; DEJANA, E. Junctional adhesion molecule, a novel member of the immunoglobulin superfamily that distributes at intercellular junctions and modulates monocyte transmigration. J. Cell. Biol., v. 142, n. 1, p. 117-127, 1998.

MASUBUCHI, Y.; KUMAI, T.; UEMATSU, A.; KOMORIYAMA, K.; HIRAI, M. Gonadectomy-induced reduction of blood pressure in adult spontaneously hypertensive rats. Acta Endocrinol., Copenhagen, v. 101, n. 1, p. 154-160, 1982.

McCARRON, R. M.; WANG, L.; SIRÉN, A. L.; SPATZ, M.; HALLENBECK, J. M. Adhesion molecules on normotensive and hypertensive rat brain endothelial cells.

Proc. Soc. Exp. Biol. Med., v. 205, n. 3, p. 257-262, 1994a.

McCARRON, R. M.; WANG, L.; SIRÉN, A. L.; SPATZ, M.; HALLENBECK, J. M. Monocyte adhesion to cerebromicrovascular endothelial cells derived from hypertensive and normotensive rats. Am. J. Physiol., v. 267, p. 2491-2497, 1994b.

McCROHON, J. A.; JESSUP, W.; HANDELSMAN, D. J.; SCELERMAJER, D. S. Androgen exposure increases human monocyte adhesion to vascular endothelium and endothelial cell expression of vascular cell adhesion molecule-1. Circulation, v. 99, p. 2317-2322, 1999.

McEVER, R. P.; BECKSTEAD, J. H.; MOORE, K. L.; MARSHALL-CARLSON, L.; BAINTON, D. F. GMP-140, a platelet alpha-granule membrane protein, is also synthesized by vascular endothelial cells and is localized in Weibel-Palade bodies. $\mathbf{J}$.

Clin. Invest., v. 84, p. 92-99, 1989.

MEHTA, J. L.; LAWSON, D. L.; NICOLINI, F. A.; ROSS, M. H.; PLAYER, D. W. Effects of activated polymorphonuclear leukocytes on vascular smooth muscle tone.

Am. J. Physiol., v. 261, p. 327-334, 1991. 
MORALES, A.; BUVAT, J.; GOOREN, L. J., GUAY, A. T.; KAUFMAN, J. M.; TAN, H. M.; TORRES, L. O. Endocrine aspects of sexual dysfunction in men. J. Sex. Med., v. 1, n. 1, p. 69-81, 2004.

MULLER, W. A. Leukocyte-endothelial-cell interactions in leukocyte transmigration and the inflammatory response. Trends Immunol., v. 24, p. 326-333, 2003.

MURPHY, J. G.; KHALIL, R. A. Decreased $\left[\mathrm{Ca}^{2+}\right](\mathrm{i})$ during inhibition of coronary smooth muscle contraction by 17 beta-estradiol, progesterone, and testosterone. $\mathbf{J}$. Pharmacol. Exp. Ther., v. 291, n. 1, p. 44-52, 1999.

NABHA, L.; GARBERN, J. C.; BULLER, C. L.; CHARPIE, J. R. Vascular oxidative stress precedes high blood pressure in spountaneoously hypertensive rats. Clin. Exp. Hypertens., v. 27, n. 1, p. 71-82, 2005.

NATHAN, C. Points of control in inflammation. Nature, v. 420, n. 6917, p. 846-852, 2002.

NIGRO, D.; SANNOMIYA, P.; CARVALHO, M. H. C.; SCIVOLETTO, R.; FORTES, Z. B. Spontaneously hypertensive versus control rat aorta response to neutrophilderived factors. Hypertension, v. 24, p. 728-733, 1994.

NORMAN. M. U.; VAN DE VELDE, N. C.; TIMOSHANKO, JR.; ISSEKUTZ, A.; HICKEY, M. J. Overlapping roles of endothelial selectins and vascular cell adhesion molecule-1 in immune complex-induced leukocyte recruitment in the cremasteric microvasculature. Am. J. Pathol., v. 163, n. 4, p. 1491-1503, 2003.

O'BRIEN, K. D.; McDONALD, T.O.; CHAIT, A.; ALLEN, M. D.; ALPERS, C. E. Neovascular expression of E-selectin, intercellular adhesion molecule-1, and vascular cell adhesion molecule-1 in human atherosclerosis and their relation to intimal leukocyte content. Circulation, v. 93, n. 4, p. 672-682, 1996.

O'BRIEN, C. D.; LIM, P.; SUN, J.; ALBELDA, S. M. PECAM-1-dependent neutrophil transmigration is independent of monolayer PECAM-1 signaling or localization. Blood, v. 101, p. $2816-2825,2003$.

OFOSU-APPIAH, W.; SFEIR, G.; SMITH, D.; RICHARD, T. Neutrophil-mediated damage to vascular endothelium in the spontaneously hypertensive rat. Clin. Immunol. Immunopathol., v. 83, n. 3, p. 293-301, 1997.

ORSHAL, J. M.; KHALIL, R. A. Gender, sex hormones, and vascular tone. Am. J. Physiol. Regul. Integr. Comp. Physiol., v. 286, n. 2, p. 233-249, 2004. 
OSTCHEGA, Y.; DILLON, C. F.; HUGHES, J. P.; CARROLL, M.; YOON, S. Trends in hypertension prevalence, awareness, treatment, and control in older U.S. Adults: data from the national health and nutrition examination survey 1988 to 2004. J. Am. Geriatr. Soc., v. 55, n. 7, p. 1056-1065, 2007.

OUCHI, Y.; SHARE, L.; CROFTON, J. T.; IITAKE, K.; BROOKS, D. P. Sex difference in the development of deoxycorticosterone-salt hypertension in the rat. Hypertension, v. 9, p. 172-177, 1987.

PANÉS, J.; KUROSE, I.; RODRIGUEZ-VACA, D.; ANDERSON, D. C.; MIYASAKA, M.; TSO, P.; GRANGER, D. N. Diabetes exacerbates inflammatory responses to ischemia-reperfusion. Circulation, v. 93, n. 1, p. 161-167, 1996.

PANÉS, J.; GRANGER, D. N. Leukocyte-endothelial cell interaction: molecular mechanisms and implications in gastrointestinal disease. Gastroenterology, v. 114, n. 5, p. 1066-1090, 1998.

PANÉS, J.; PERRY, M.; GRANGER, C. N. Leukocyte-endothelial cell adhesion: avenues for therapeutic intervention. Br. J. Phamacol., v. 126, p. 537-550, 1999.

PARISSIS, J. T.; VENETSANOU, K. F.; KALANTZI, M. V.; MENTZIKOF, D. D.; KARAS, S. M. Serum profiles of granulocyte-macrophage colony-stimulating factor and $\mathrm{C}-\mathrm{C}$ chemokines in hypertensive patients with or without significant hyperlipidemia. Am. J. Cardiol., v. 85, n. 6, p. 777-779, 2000.

PARISSIS, J. T.; KOROVESIS, S.; GIAZITZOGLOU, E.; KALIVAS, P.; KATRITSIS, D. Plasma profiles of peripheral monocyte-related inflammatory markers in patients with arterial hypertension. Correlations with plasma endothelin-1. Int. J. Cardiol., v. 83, n. 1, p. 13-21, 2002.

PASSAGLIA, R. C. A. T.; NIGRO, D.; FORTES, Z. B.; SCIVOLETTO, R.; CARVALHO, M. H. C. Endotélio, aspectos fisiológicos. Hipertensão, v. 1, p. 94-101, 1998.

PATEL, K. D.; CUVELIER, S. L.; WIEHLER, S. Selectins: critical mediators of leukocyte recruitment. Semin. Immunol., v. 14, n. 2, p. 73-81, 2002.

PAULETTO, P.; RATTAZZI, M. Inflammation and hypertension: the search for a link. Nephrol. Dial Transplant., v. 21, p. 850-853, 2006.

PFAFFL, M. W. A new mathematical model for relative quantification in real-time RTPCR. Nucleic Acids Res., v. 29, n. 9, p. 45, 2001. 
PIALI, L.; ALBELDA, S. M.; BALDWIN, H. S.; HAMMEL, P.; GISLER, R. H.; IMHOF, B. A. Murine platelet endothelial cell adhesion molecule-1 (PECAM-1)/CD31 modulates $\beta 2$ integrins on lymphokine activated killer cells. Eur. J. Immunol., v. 23, p. 2464-2471, 1993.

PRENTICE, R. L.; SZATROWSKI, T. P.; KATO, H.; MASON, M. W. Leukocyte counts and cerebrovascular disease. J. Chron. Dis., v. 35, p. 703-714, 1982.

QUAN, A.; TEOH, H.; MAN, R. Y. Acute exposure to a low level of testosterone impairs relaxation in porcine coronary arteries. Clin. Exp. Pharmacol. Physiol., v. 26, p. 830-832, 1999.

RANKIN, J. A.; SYLVESTER, I.; SMITH, S.; YOSHIMURA, T.; LEONARD,E. J. Macrophages cultured in vitro release leukotriene B4 and neutrophil attractant/activation protein (interleukin 8) sequentially in response to stimulation with lipopolysaccharide and zymosan. J. Clin. Invest., v. 86, p. 1556-1564, 1990.

RECKELHOFF, J. F.; ZHANG, H.; GRANGER, J. P. Testosterone exacerbates hypertension and reduces pressure-natriuresis in male spontaneousy hypertensive rats. Hypertension, v. 31, p. 435-439, 1998.

RECKELHOFF, J. F.; ZHANG, H.; SRIVASTAVA, K.; GRANGER, J. P. Gender differences in hypertension in spontaneously hypertensive rats : Role of androgens and androgen receptor. Hypertension, v. 34, p. 920-923, 1999.

RECKELHOFF, J. F.; ZHANG, H.; SRIVASTAVA, K. Gender differences in development of hypertension in spontaneously hypertensive rats: role of the renninangiotensin systen. Hypertension, v. 35, p. 480-483, 2000.

RECKELHOFF, J. F. Gender differences in the regulation of blood pressure. Hypertension, v. 37, n. 5, p. 1199-1208, 2001.

RECKELHOFF, J. F. Sex steroids, cardiovascular disease, and hypertension: unanswered questions and some speculations. Hypertension, v. 45, n. 2, p. 170174, 2005.

RECKELHOFF, J. F.; YANES, L. L.; ILIESCU, R.; FORTEPIANI, L. A.; GRANGER, J. $P$. Testosterone supplementation in aging men and women: possible impact on cardiovascular-renal disease. Am. J. Physiol. Renal Physiol., v. 289, n. 5, p. 941948, 2005.

ROWLAND, N. E.; FREGLY, M. J. Role of gonadal hormones in hypertension in the Dahl salt-sensitive rat. Clin. Exp. Hypertens., v. 14, p. 367-375, 1992. 
SCALIA, R.; LEFER, A. M. In vivo regulation of PECAM-1 activity during acute endothelial dysfunction in the rat mesenteric microvasculature. J. Leukoc. Biol., v. 64, p. 163-169, 1998.

SCHMID-SCHÖENBEIN, G. W.; FUNG, Y. C.; ZWEIFACH, B. W. Vascular endothelium-leukocyte interaction, sticking shear force in venules. Circ. Res., v. 36, p. 173-184, 1975.

SCHMID-SCHÖNBEIN, G. W.; SEIFFGE, D.; DELANO, F. A.; SHEN, K.; ZWEIFACH, B. W. Leukocyte counts and activation in spontaneously hypertensive and normotensive rats. Hypertension, v. 17, n. 3, p. 323-330, 1991.

SCHMID-SCHÖENBEIN, G. W.; ZWEIFACH, B. W.; MOAZZAM, F. Mechanisms of leukocyte activation in the circulation. Atherosclerosis, v. 131, p. 23-25, 1997.

SCHRÖR, K.; MORINELLI, T. A.; MASUDA, A.; MATSUDA, K.; MATHUR, R. S.; HALUSHKA, P. V. Testosterone treatment enhances thromboxane A2 mimetic induced coronary artery vasoconstriction in guinea pigs. Eur. J. Clin. Invest., v. 24, p. 50-52, 1994.

SHEN, K.; DELANO, F. A.; ZWEIFACH, B. W. Circulating leukocyte counts, activation, and degranulation in Dahl hypertensive rats. Circ. Res., v. 76, n. 2, p. 276-283, 1995.

SILVA-ANTONIALLI, M. M.; FORTES, Z. B.; CARVALHO, M. H. C.; SCIVOLETTO, R.; NIGRO, D. Sexual dimorphism in the response of thoracic aorta from SHRs to losartan. Gen. Pharmacol., v. 34, n. 5, p. 329-335, 2000.

SINHA-HIKIM, I.; TAYLOR, W. E.; GONZALEZ-CADAVID, N. F.; ZHENG, W.; BHASIN, S. Androgen receptor in human skeletal muscle and cultured muscle satellite cells: up-regulation by androgen treatment. J. Clin. Endocrinol. Metab., v. 89 , n. 10, p. 5245-5255, 2004.

SPARK, R. F. Intrinsa fails to impress FDA advisory panel. Int. J. Impot. Res., v. 17, p. 283-284, 2005.

SPERTINI, O.; KANSAS, G. S.; MUNRO, J. M.; GRIFFIN, J. D.; TEDDER, T.F. Regulation of leukocyte migration by activation of the leukocyte adhesion molecule-1 (LAM-1) selectin. Nature, v. 349, p. 691-694, 1991.

SPRINGER, T. A. Traffic signals for lymphocyte recirculation and leukocyte emigration: the multistep paradigm. Cell, v. 76, n. 2, p. 301-314, 1994. 
SUZUKI, H.; SUEMATSU, M.; SHAN, Y.; KUROSE, I.; FUKUMURA, D.; MIURA, S.; TSUCHIYA, M. Mast cell degranulation during microcirculatory disturbances revealed by the toluidine blue vital staining method. In: TSUCHIYA, M.; NAGURA, H.; HIBI, T.; MORO, I. (Ed.). Frontiers of Mucosal Immunology. Amsterdam, Netherlands: Elsevier, 1991. p.549-550.

TAILOR, A.; GRANGER, D. N. Role of adhesion molecules in vascular regulation and damage. Curr. Hypertens. Rep., v. 2, p. 78-83, 2000.

TALBOTT, E.; GUZICK, D.; CLERICI, A.; BERGA, S.; DETRE, K.; WEIMER, K.; KULLER, L. Coronary heart disease risk factors in women with polycystic ovary syndrome. Arterioscler. Thromb. Vasc. Biol., v. 15, p. 821- 826, 1995.

TANAKA, Y.; ALBELDA, S. M.; HORGAN, K. J.; VAN-SEVENTER, G. A.; SHIMIZU, Y.; NEWMAN, W.; HALLAN, J.; NEWMAN, P. J.; BUCK, C. A.; SHAW, S. CD31 expressed on distinctive $T$ cell subsets is a preferential amplifier of $\beta 1$ integrinmediated adhesion. J. Exp. Med., v. 176, p. 245-253, 1992.

TARIQ, S. H.; HAREN, M. T.; KIM, M. J.; MORLEY, J.E. Andropause: is the emperor wearing any clothes? Rev. Endocr. Metab. Disord., v. 6, n. 2, p. 77-84, 2005.

TOSTES, R. C. A.; DAVID, F. L.; CARVALHO, M. H. C.; NIGRO, D.; SCIVOLETTO, R.; FORTES, Z. B. Gender differences in vascular reactivity to endothelin-1 in deoxycortiscosterone-salt hypertensive rats. J. Cardiovasc. Pharmacol., v. 36, p. 99-101, 2000.

TOUYZ, R. M. Reactive oxygen species, vascular oxidative stress, and redox signaling in hypertension: What is the clinical significance? Hypertension, v. 44, n. 3, p. 248-252, 2004.

TSAO, P. S.; NIEBAUER, J.; BUITRAGO, R.; LIN, P. S.; WANG, B. Y.; COOKE, J. P.; CHEN, Y.I.; REAVEN, G. M. Interaction of diabetes and hypertension on determinants of endothelial adhesiveness. Arterioscler. Thromb. Vasc. Biol., v. 18, p. 947-953, 1998.

TURNER, H.; WASS, J. Declining gonadal function in men with chronic disease. Clin. Endocrinol., v. 47, p. 379-403, 1997.

VERMEULEN, A. Andropause. Maturitas, v. 34, n. 1, p. 5-15, 2000.

WEISS, S. J.; LOBUGLIO, A. F. Biology of disease: phagocyte-generated oxygen metabolites and cellular injury. Lab. Invest., v. 47, p. 5-18, 1982. 
WEISS, S. J. Tissue destruction by neutrophils. N. Engl. J. Med., v. 320, p. 365-376, 1989.

WILHELM, D. L. Inflammation and healing. In: ANDERSON, W. A. D.; KISSANE, J. M. Pathology. 7th. ed. St. Louis: Mosby, 1977. p.75-89.

XUE, B.; PAMIDIMUKKALA, J.; HAY, M. Sex differences in the development of angiotensin Il-induced hypertension in conscious mice. Am. J. Physiol. Heart Circ. Physiol., v. 288, p. 2177-2184, 2005.

YUE, P.; ChAtTeRJee, K.; BeAle, C.; POOle-WILSON, P. A.; COllins, P. Testosterone relaxes rabbit coronary arteries and aorta. Circulation, v. 91, n. 4, p. 1154-1160, 1995.

ZHANG, X.; WANG, L. Y.; JIANG, T. Y.; ZHANG, H. P.; DOU, Y.; ZHAO, J. H.; ZHAO, H.; QIAO, Z. D.; QIAO, J. T. Effects of testosterone and 17-h-estradiol on TNF-a-induced E-selectin and VCAM-1 expression in endothelial cells Analysis of the underlying receptor pathways. Life Sci., v. 71, p. 15-29, 2002.

ZWEIFACH, B. W. Indirect methods for regional blood flow. I. Microscopic observation of circulation in rat mesoappendix and dog omentm. Use in study of vasotropic substances. Methods Med. Res., v. 1, p. 131-138, 1948. 